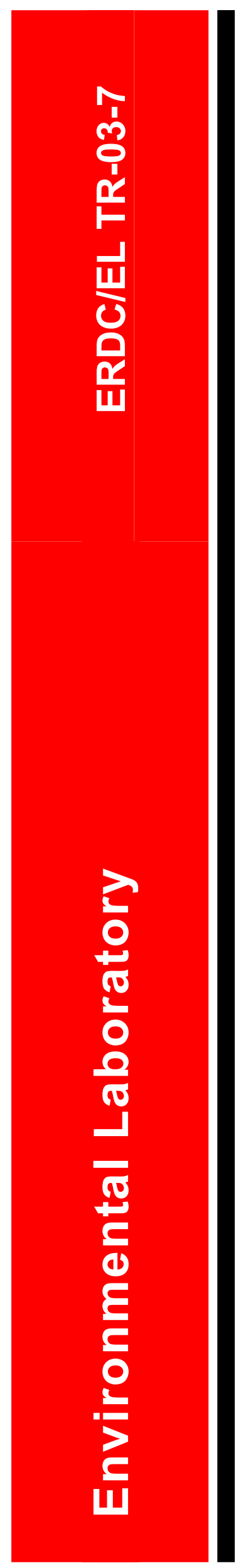

Dredging Operations Technical Support Program

Beneficial Use of Dredged Bedrock in the New York/New Jersey Harbor

Joel Banslaben, Jack C. Cox, and Robert J. Will

July 2003 


\section{Beneficial Use of Dredged Bedrock in the New York/New Jersey Harbor}

Joel Banslaben

Battelle Memorial Institute

Coastal Resources and Environmental Management

1212 Route 25A

Stony Brook, NY 11790

Jack C. Cox

PBS \& $J$

3859 Centerview Drive

Chantilly, VA 20151

Robert J. Will

U.S. Army Engineer District, New York

26 Federal Plaza

New York, NY 10278

Final report

Approved for public release; distribution is unlimited

Prepared for U.S. Army Engineer District, New York 26 Federal Plaza, New York, NY 10278

Monitored by Environmental Laboratory

U.S. Army Engineer Research and Development Center 3909 Halls Ferry Road, Vicksburg, MS 39180-6199 


\begin{abstract}
Maintaining economic viability in the rapidly developing global marketplace is a major priority of ports nationwide. It is imperative that commercial ports, such as those in New York (NY) and New Jersey (NJ), evolve to remain competitive with developing global infrastructure. As a consequence, the U.S. Army Engineer District, New York, and the Port Authority of New York and New Jersey are going forward with plans to deepen existing channels for use by the newest generation of container ships. This will include the deepening of several waterways, most prominently the Kill van Kull (KVK), Arthur Kill (AK), and Port Jersey Channel, to a depth of $50 \mathrm{ft}$. A significant by-product of each deepening project will be large amounts of dredged material. In the case of the KVK and AK, the material will be composed predominantly of bedrock. As a result, the U.S. Army Corps of Engineers has commissioned a series of investigations into the viability of beneficially using dredged bedrock in the NY/NJ Harbor.

This report outlines how numerous beneficial use opportunities can become feasible based on bedrock characteristics, case-specific constraints, and applicable regulatory concerns. Beneficial uses of bedrock are promoted by legislative acts. A few uses have been practiced routinely in this region. This report seeks to highlight considerations toward broader uses of bedrock commensurate with projected dredging volumes. This report does not seek to compare the relative merit or cost differential between viable beneficial use opportunities. Information regarding the method for determining the feasibility assessments is detailed.

Understanding the type, quantity, and character of material that will be produced as a result of planned dredging projects generates greater understanding of the issues surrounding the beneficial use of dredged bedrock. This information allows project sponsors to determine potential suitable uses for the material. These uses can then be analyzed in more detail to determine the optimal combination of environmental benefits and costs. Once the geological characteristics have been defined, implementation issues can be identified and addressed. These issues can include environmental, economic, federal and nonfederal institutional, engineering, and regulatory. In addition, this report offers a logical framework for examining material characteristics and major constraints facing each of the potential beneficial uses of dredged bedrock.
\end{abstract}

DISCLAIMER: The contents of this report are not to be used for advertising, publication, or promotional purposes. Citation of trade names does not constitute an official endorsement or approval of the use of such commercial products. All product names and trademarks cited are the property of their respective owners. The findings of this report are not to be construed as an official Department of the Army position unless so designated by other authorized documents.

DESTROY THIS REPORT WHEN IT IS NO LONGER NEEDED. DO NOT RETURN TO THE ORIGINATOR. 


\section{Contents}

Conversion Factors, Non-SI to SI Units of Measurement.................................. vi

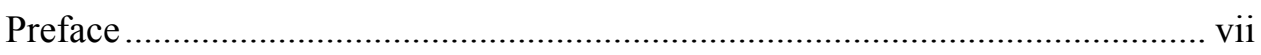

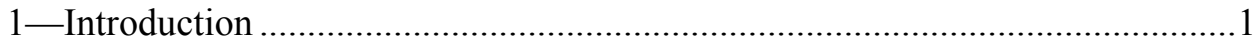

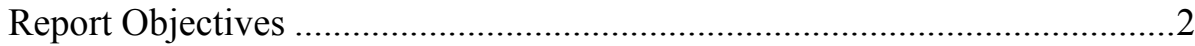

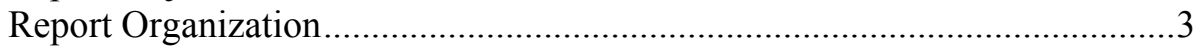

2-Overview: Beneficial Uses of Dredged Bedrock ..........................................4

Historical Beneficial Uses of Dredged Bedrock ...........................................4

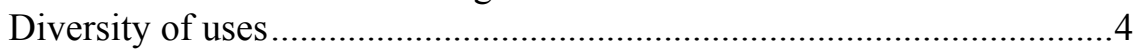

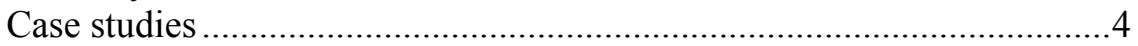

Potential Beneficial Use Options for Dredged Bedrock ................................ 8

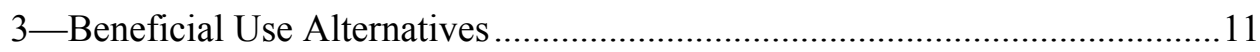

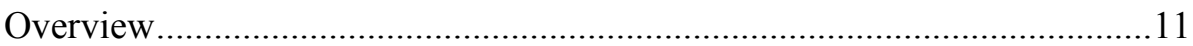

Artificial Reefs (Recreational Fishing and Diving) ...................................11

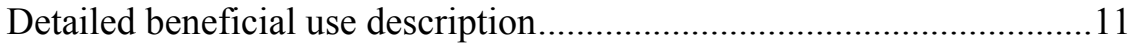

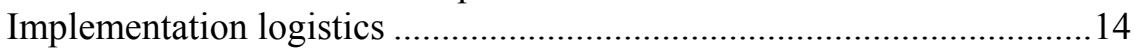

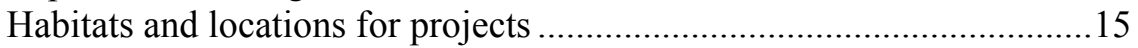

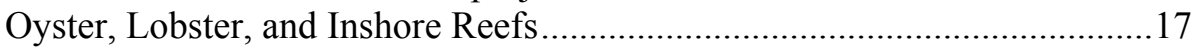

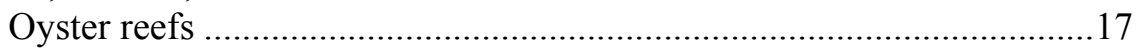

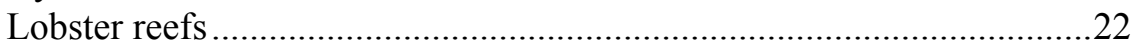

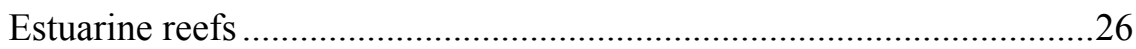

Nearshore Wave-Attenuation Devices.........................................................30

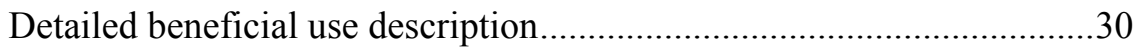

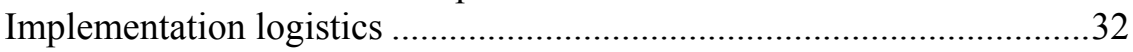

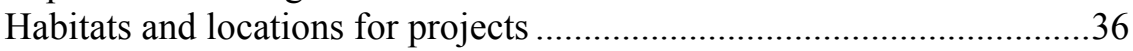

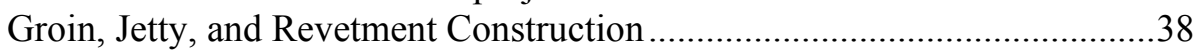

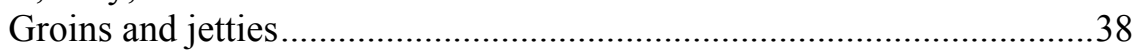

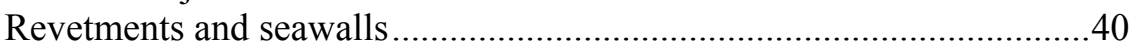

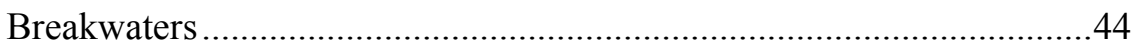

Reduction of Loss for Salt Marsh, Mud Flat, and Shallow Habitats .............45

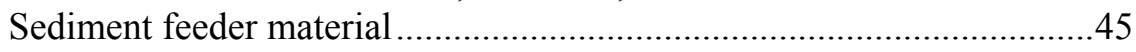

Habitat restoration, enhancement, and creation ....................................4

Commercial Sale of Dredged Material ..................................................50

Detailed beneficial use description.......................................................50

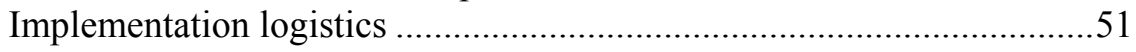

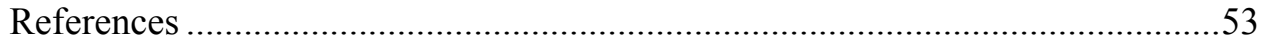


Appendix A: Geological Specifications

Appendix B: Overview of Beneficial Use of Dredged Bedrock: Issue

Analysis

Appendix C: Decisionmaking Tools and Framework Overview

Appendix D: Vessel-Generated Wave Calculations

D1

Appendix E: Essential Fish Habitat for Life History Stages of Managed

Species in Vicinity of Artificial Reef Sites in New York.

Appendix F: Essential Fish Habitat for Life History Stages of Managed

Species in Vicinity of Artificial Reef Sites in New Jersey F1

SF 298

\section{List of Figures}

Figure 1. New York/New Jersey Harbor overview ...................................

Figure 2. Permitted artificial reef sites in New York and New Jersey

Figure 3. Location of existing artificial oyster reefs in the NY/NJ

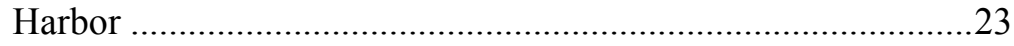

Figure 4. Potential location for artificial lobster reefs in the NY/NJ Harbor

Figure 5. Potential locations for artificial estuarine reefs in the NY/NJ Harbor ....

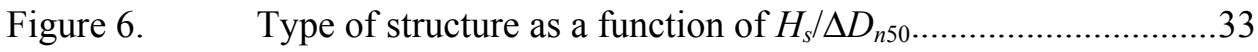

Figure 7. Nondeformable rubble structures …...........................................34

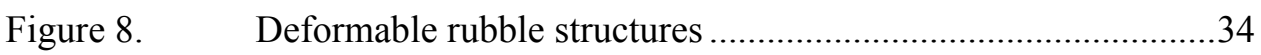

Figure 9. Wave transmission over low-crested structures .........................35

Figure 10. Potential locations for wave-attenuating structures in the NY/NJ Harbor .37

Figure 11. Potential locations for beneficial use of bedrock for shoreline rotection in Town of Hempstead 


\section{List of Tables}

Table 1. Historical Beneficial Uses of Dredged Bedrock ..........................5

Table 2. Potential Beneficial Uses of Dredged Bedrock .........................10

Table 3. Species Likely to Benefit from Artificial Reefs in New York and New Jersey ..............................................................16

Table 4. Characteristics of Artificial Reef Sites in New York and New Jersey ......................................................................... 18

Table 5. Characteristics of Proposed Artificial Reef Sites in New

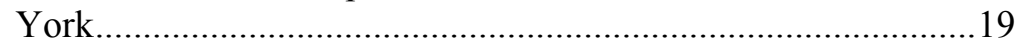

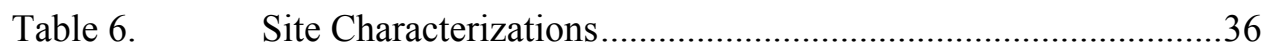

Table 7. Commercial Costs and Sale Specifications ................................52 


\section{Conversion Factors, Non-SI to SI Units of Measurement}

Non-SI units of measurement used in this report can be converted to SI units as follows:

\begin{tabular}{||l|c|l||}
\hline \hline Multiply & \multicolumn{1}{|l||}{ By } & To Obtain \\
\hline \hline acres & $4,046.873$ & square meters \\
\hline bushels (U.S.) & 0.03523 & cubic meters \\
\hline cubic yards & 0.7645549 & cubic meters \\
\hline cubic yards per foot & 2.51 & cubic meters per meter \\
\hline degrees (angle) & 0.01745329 & radians \\
\hline degrees Fahrenheit & $5 / 9$ & degrees Celsius or kelvins \\
\hline feet & 0.3048 & meters \\
\hline inches & 0.0254 & meters \\
\hline miles (U.S. nautical) & 1.852 & kilometers \\
\hline miles (U.S. statute) & 1.609347 & kilometers \\
\hline pounds (mass) & 0.4535924 & kilograms \\
\hline square feet & 0.09290304 & square meters \\
\hline square feet per foot & 0.3 & square meters per meter \\
\hline tons (2,000 pounds, mass) & 907.1847 & kilograms \\
\hline yards & 0.9144 & meters \\
\hline \hline $\begin{array}{l}1 \\
\text { To obtain Celsius (C) temperature readings from Fahrenheit }(\mathrm{F})\end{array}$ & readings, use the following \\
\hline \hline
\end{tabular}




\section{Preface}

This report was written by Joel Banslaben, Battelle Memorial Institute, Stony Brook, NY; Jack C. Cox, PBS \& J, Chantilly, VA; and Robert J. Will, U.S. Army Engineer District, New York.

The authors wish to extend their gratitude to the following contributors: Mr. Leonard Houston, Mr. Robert J. Will, Mr. James Lodge, Mr. Bryce Wisemiller, Dr. Stephen Knowles, Mr. Steven Weinberg, Ms. Diane Rahoy, Ms. Jenine Gallo, Mr. Thomas J. Shea III, and Dr. David Yang, U.S. Army Engineer District, New York; Dr. Douglas Clarke and Dr. Andy Morang, U.S. Army Engineer Research and Development Center (ERDC); Mr. Steve Heins, New York State Department of Environmental Conservation; Mr. Mike Stringer, New York/New Jersey Baykeeper; Mr. William Figley, New Jersey Department of Environmental Protection; Mr. Mike Ludwig and Mr. Frank Steimle, National Marine Fisheries Service; and Mr. Ron Masters, Town of Hempstead, Nassua County, New York.

Acting Director of the Environmental Laboratory was Dr. Elizabeth C. Fleming.

COL John W. Morris III, EN, was Commander and Executive Director of ERDC. Dr. James R. Houston was Director. 


\section{Introduction}

Maintaining economic viability in the rapidly developing global marketplace is a major priority of ports nationwide. It is imperative that commercial ports, such as those in New York (NY) and New Jersey (NJ), evolve to remain competitive with developing global infrastructure. As a consequence, the U.S. Army Engineer District, New York, and the Port Authority of New York and New Jersey are going forward with plans to deepen existing channels for use by the newest generation of container ships. This will include the deepening of several waterways, most prominently the Kill van Kull (KVK), Arthur Kill (AK), and Port Jersey (PJ) Channel, to a depth of $50 \mathrm{ft}^{1}$ (U.S. Army Corps of Engineers (USACE) 1999b). A significant by-product of each deepening project will be large amounts of dredged material. In the case of the KVK and AK, the material will be composed predominantly of bedrock. As a result, the USACE has commissioned a series of investigations into the viability of beneficially using dredged bedrock in the NY/NJ Harbor.

Final studies to dredge the KVK, AK, and PJ have been completed, and contracts with the respective dredging organizations are in progress. As part of ongoing deepening projects, the USACE is blasting and dredging significant volumes of bedrock. The estimated year of completion for these projects is 2016, contingent on funding and other logistical factors. Several of the major dredging projects coincide geographically, and it may be optimal to combine projects in order to maximize resource use and limit environmental effects that may affect the local residents and industry. For this reason, the entire dredging project schedule could be accelerated.

Research of historical uses of bedrock material helps assess the viability for beneficial rock uses. Historical records of bedrock-generating projects reveal that beneficial use of this material is not well documented. However, the volumes to be generated as part of the NY/NJ Harbor Deepening project far exceed the volumes produced in previous dredging operations. Studies of the channels and harbors suggest that the dredging projects will produce a mix of material including silt, mud, clay, and various types of bedrock. The generation of 8.6 million cubic yards of bedrock provides the USACE with the opportunity to examine innovative uses of this material.

A screening level alternatives analysis based on historical beneficial uses projects allows for the examination of key factors in implementing beneficial use

1 A table of factors for converting U.S. customary units of measurement to metric (SI) is presented on page vi. 
options in the NY/NJ Harbor. The information generated in this report can provide a baseline of information for making decisions regarding the beneficial use of dredged bedrock from a wide spectrum of perspectives. This may allow for pilot projects to be implemented to validate key assumptions regarding beneficial use of bedrock.

\section{Report Objectives}

To best assess the use of dredged bedrock material in the NY/NJ Harbor, the USACE has set objectives that focus on beneficial use and local ecosystems. This report examines the potential options for using rock that will be generated in the $\mathrm{KVK}, \mathrm{AK}$, and $\mathrm{PJ}$ with respect to beneficial use alternatives for habitat enhancement and protection. The objectives of this report are to:

a. Present the findings of a series of investigations for beneficially using dredged bedrock in the NY/NJ Harbor.

b. Review the historical uses of dredged bedrock in the USACE Districts nationwide, governments internationally, and private sources elsewhere.

c. Review the current research on the beneficial use of dredged bedrock for environmental projects, including a detailed analysis of material type, volumes, sponsoring entity, extent of implementation, location of placement, methods of blasting/dredging, and constraints.

d. Identify constraints to implementing beneficial use projects in the region and then proposing solutions for addressing those limitations.

e. Provide a logical framework enabling decisionmakers to determine the viability of beneficial use options with respect to environmental, economic, regulatory, institutional, and engineering factors.

Several assumptions were made during the screening level alternatives analysis of dredged bedrock. One of the major limitations to creating a database of information is lack of documentation of beneficial use projects with dredged bedrock. This may be a by-product of historical practices that did not consider rock as a resource product of dredging activities. The majority of the information found in this report is original hypothesis on how bedrock may respond in different beneficial use settings. The lack of historical information limits the extent to which the issues and recommendations in the report could be supported. A significant amount of information in each section is a product of personal communication with policy makers, scientific experts, and stakeholders.

Additionally, several of the evaluations of capacity for habitat enhancement were based on assumptions of ideal habitat for the species. If species compositions are different than those to be expected, there is potential for variation in habitat values. The estimations of processing, sorting, and storage capacities for aggregate companies are general estimations due to aggregate industry practices. 


\section{Report Organization}

An examination of historical beneficial use projects can be found in Chapter 2 of this report. Each project provides insight into the logistics of implementing future beneficial use alternatives. It should be noted here that some historical projects that have not been labeled "beneficial use" are included in the review due to their value in habitat creation and enhancement. Following the historical uses section, an overview of the potential beneficial use options can be found.

Chapter 3 presents detailed information regarding each specific beneficial use option. Information is divided into sections including beneficial use descriptions, implementation logistics, constraints to implementation, and potential habitats for placement. These sections should be analyzed thoroughly in conjunction with the appendices when assessing any beneficial use option. This will ensure that all information is properly interpreted and analyzed. Sections here can be found on artificial reefs, oyster reefs, lobster reefs, inshore reefs, wave-attenuating devices, groins and jetties, revetments, seawalls, breakwaters, and other alternative options. Sections detailing how to best use dredged bedrock material to mitigate loss of salt marsh, mud flat, and shallow water habitat can also be found here.

Appendix A, which offers a detailed analysis of the geological factors involved in beneficial use implementation, also provides detailed information on expected rock types and volumes that will be generated in the KVK, AK, and PJ, as well as information regarding the four major rock types and their applicability in beneficial use alternatives. Appendix B outlines the issues affecting the implementation of beneficial use options. Each issue is examined, followed by recommendations for mitigating adverse effects. Appendix $\mathrm{C}$ outlines the beneficial use decisionmaking processes with flow charts and information for implementation. Appendix D examines the characteristics of ship-generated waves. Appendices $\mathrm{E}$ and $\mathrm{F}$ display the essential fish habitats for the region. 


\section{Overview: Beneficial Uses of Dredged Bedrock}

\section{Historical Beneficial Uses of Dredged Bedrock}

\section{Diversity of uses}

An overview of the historical beneficial uses of dredged material provides a valuable starting point for creating a manual of potential alternatives available to resource managers. The diversity of uses historically employed by dredging operations illustrates the opportunity that exists with this medium. Dredged material such as sand and fine gravel has been applied to storm damage reduction activities such as beach nourishment and dune reconstruction and can also be used to create temporary groin fields for shoreline protection. The material can also be used by quarries to supply entities with quality construction fill and by cement plants to create concrete for building and roadway construction.

A significant portion of dredged material is composed of bedrock. These materials present resource managers with several options for beneficial use due to the consistent, and often clean, nature of the material. The removal and placement of rock is an arduous task, complicated by environmental and safety issues. Rock dredged from waterways has typically been disposed in designated offshore disposal sites or used for artificial reefs within close proximity to the outer harbor entrance. The availability of disposal sites for bedrock is often contingent upon reef site location and capacity. Other uses have included shore protection and habitat enhancement.

In the United States, District offices of the USACE have regulatory supervision over navigation deepening projects and, therefore, store information with respect to dredged material disposal. In reviewing District databases, only a handful of projects were identified where rock has been removed (Table 1). National and international uses of dredged bedrock are reviewed in the following case studies.

\section{Case studies}

Wilmington, NC. Currently, the main approach channels in the Cape Fear River, leading up to the State Port of Wilmington, North Carolina, are being 


\begin{tabular}{|c|c|c|c|c|c|c|}
\hline Beneficial Use & Location & $\begin{array}{l}\text { Material } \\
\text { Type }^{1}\end{array}$ & $\begin{array}{l}\text { Volume } \\
\text { cu yd }\end{array}$ & $\begin{array}{l}\text { Size } \\
\text { (diameter) } \\
\mathrm{ft} \\
\end{array}$ & Implementing Agency & $\begin{array}{l}\text { Dredging } \\
\text { Method }^{2} \\
\end{array}$ \\
\hline \multicolumn{7}{|c|}{ Reef Development/ Habitat Enhancement } \\
\hline \multirow[t]{3}{*}{ Artificial reef } & $\begin{array}{l}\text { Pier } 400, \\
\text { Los Angeles, CA }\end{array}$ & $\mathrm{SH}$ & 225,000 & $0.6-1.5$ & $\begin{array}{l}\text { USACE - Los Angeles, } \\
\text { LA Port Authority }\end{array}$ & M \\
\hline & Various Inlets, FL & $\mathrm{LI}$ & $100,000+$ & $3-10$ & $\begin{array}{l}\text { USACE, State \& County } \\
\text { DEP }\end{array}$ & $B, M$ \\
\hline & $\begin{array}{l}\text { Port of Tauranga, } \\
\text { New Zealand }\end{array}$ & B & 250,000 & $1-6.5$ & $\begin{array}{l}\text { New Zealand Port } \\
\text { Authority }\end{array}$ & M \\
\hline Crustacean habitat & $\begin{array}{l}\text { Port of Felixstowe, } \\
\text { United Kingdom } \\
\text { (UK) }\end{array}$ & SA & - & $1-10$ & Harwich Haven Authority & $\mathrm{M}$ \\
\hline \multirow[t]{4}{*}{ Offshore disposal } & $\begin{array}{l}\text { Jebal Ali Harbor, } \\
\text { United Arab } \\
\text { Emirates } \\
\end{array}$ & $\mathrm{LI}$ & - & $1-5$ & $\begin{array}{l}\text { United Arab Emirates - } \\
\text { Dubai }\end{array}$ & $\mathrm{B}$ \\
\hline & $\begin{array}{l}\text { Cape Fear River, } \\
\text { Wilmington, NC }\end{array}$ & $\mathrm{LI}$ & 500,000 & $>1.5$ & USACE - Wilmington & $B, M$ \\
\hline & $\begin{array}{l}\text { Umpqua River \& } \\
\text { Coos Bay, OR }\end{array}$ & $\mathrm{B}$ & - & - & USACE - Portland & $\mathrm{B}, \mathrm{M}$ \\
\hline & $\begin{array}{l}\text { San Francisco } \\
\text { Harbor, CA }\end{array}$ & G & - & $3-10$ & USACE - San Francisco & $\mathrm{B}, \mathrm{M}$ \\
\hline \multicolumn{7}{|c|}{ Shoreline Stabilization/ Engineered Uses } \\
\hline \multirow[t]{2}{*}{ Revetments, dykes } & Detroit River, MI & $\mathrm{LI}$ & - & $1-10$ & USACE - Detroit & $\mathrm{B}, \mathrm{M}$ \\
\hline & St. Mary's River, MI & $\mathrm{LI}$ & - & $1-10$ & USACE - Detroit & $\mathrm{B}, \mathrm{M}$ \\
\hline $\begin{array}{l}\text { Shoreline } \\
\text { protection }\end{array}$ & Sault St. Marie, MI & SA & 300,000 & $3-8$ & USACE - Detroit & $\mathrm{M}$ \\
\hline Seawalls & $\begin{array}{l}\text { Port of Felixstowe, } \\
\text { Harwich, UK }\end{array}$ & SA & - & $1-10$ & Harwich Haven Authority & $\mathrm{M}$ \\
\hline $\begin{array}{l}\text { Sediment feeder } \\
\text { material }\end{array}$ & $\begin{array}{l}\text { Mississippi River, } \\
\text { St. Louis, MO }\end{array}$ & SA & 250,000 & - & USACE - St. Louis & $\mathrm{D}$ \\
\hline Breakwater & $\begin{array}{l}\text { Ouzinkie Harbor, } \\
\text { Kodiak Island, AK }\end{array}$ & $\mathrm{G}$ & 50,000 & $3-10$ & USACE - Alaska & $D, B$ \\
\hline
\end{tabular}

dredged as part of a harbor-deepening project. Near Keg Island and Big Island, blasting of the existing navigation channel resulted in the production of laminated limestone (Castle Hayne). The limestone, which is intermixed with shell shards, produces fragments less than $1.5 \mathrm{ft}$ in diameter during excavation and is considered a capstone material. Due to its fragmented character, the Wilmington District determined that the limestone has limited upland or commercial applications. There is a possibility the material could be used to create underwater habitat, but the 0.5 million cubic yards of rock dredged is currently dumped offshore in a designated disposal area.

Jacksonville, FL. Jacksonville District has used Coquina limestone extensively in the region for artificial reef habitat. Limestone is generally soft and can be mechanically removed as in the cases of Miami Harbor, Port Everglades, Fort Pierce, and St. Lucie Inlet. In a pending Hillsboro project, it is projected that 
some material may need to be blasted before removal. In all cases, rock is placed offshore in a confined disposal area and categorized as created reef habitat.

Great Lakes. In the Great Lakes region, substantial rock removal has not occurred since the late 1950s and early 60s when several channel-deepening projects such as those between the Great Lakes in the Detroit River (Lake Erie to Lake St. Clair and Lake Huron) and the St. Mary's River (Lake Huron to Lake Superior) were completed. For those projects, the limestone encountered was blasted into small pieces and side cast onto the dikes lining either side of the channel. These dikes served as "compensating structures" to restrict river flows which would increase due to deepened channels. In other cases, the stone was stockpiled and used for navigation purposes such as riprap to prevent erosion of shoreline or building or reinforcing docks. The size of the stone varied up to several hundred pounds, with a small percentage in the 1- to 2-ton range.

St Mary's River. In the 1960s the Detroit District excavated bedrock from the St. Mary's River. Cofferdams were built to isolate the riverbed and then water was drained from the location to expose the bedrock at the bottom. Rock was excavated from a depth of 10 to $28 \mathrm{ft}$ under dry conditions using quarrying methods. The rock was then used to construct walls of $4 \mathrm{ft}$ in height at the edges of the channels.

Sault St. Marie. This ongoing Detroit District project in the Sault St. Marie waterway has used boring techniques to remove approximately $35,000 \mathrm{cu}$ yd of sandstone at a cost of $\$ 30 / \mathrm{cu}$ yd. Material over $75 \mathrm{lb}$ was used to line sandy bank areas of the channel. It is expected that 200,000 to $300,000 \mathrm{cu}$ yd of material will eventually be removed.

Los Angeles, CA. As part of the Pier 400 expansion project at the Port of Los Angeles, a new navigation channel leading to Pier 400 had to be dredged. The alignment of the new channel placed it over a significant area of rocky substrate that is an active fishing habitat. Working in cooperation with local fisherman, the harbor pilot's association, the Port Authority, the Los Angeles District, and other federal agencies, a suitable nearshore location was selected to dump the dredged rock to create a system of artificial reefs. Mudstone, a rocky substrate similar to shale, ranging in size from 0.5 to $1.5 \mathrm{ft}$ in diameter was produced. Approximately 225,000 cu yd of material was dumped in 36 discrete systems. Based on preliminary monitoring of the constructed reefs, it appears that the mudstone has created a very effective habitat.

San Francisco, CA. San Francisco District has historically excavated bedrock from San Francisco Harbor and placed it offshore of the dredging location. This could be construed as artificial reef creation although no documentation of this use is recorded. Notably, however, San Francisco authorities are preparing to further deepen their harbor and are currently assessing their dredging needs and issues.

Portland, OR. The mouths of the Umpqua River and Coos Bay were dredged during the late 1970s by the Portland District to improve access to the inland river port facilities. Igneous rock (basalt) extracted from the channel was 
sent to an approved offshore disposal site. The last major deepening project in the Columbia River required the removal of rock with disposal being handled by placing the excess material within existing deepwater holes in the river.

Ouzinkie Harbor, AK. In the Alaska District work is being performed on the Ouzinkie Harbor in Kodiak Island to drill and blast bedrock from shipping channels. The USACE is planning to utilize material of proper specifications to develop the core of a breakwater in the region. If the material does not meet engineering specifications, it will be placed offshore.

Mississippi River. In St. Louis, sandstone has been excavated from the Mississippi River with the use of pneumatic underwater drills. This causes the material to fracture extensively and limits its application for beneficial use. The majority of the material is placed along the banks of the river for shore protection.

United Kingdom. At the Port of Felixstowe near Harwich, UK, the Harwich Haven Authority has recently deepened the main access channel. During the process, they encountered concentrations of sandstone nested between several sandy clay layers. The sandstone is generally calcareous cement but becomes siliceous cement sandstone near fault lines. The sandstone had a very high crushing strength, but low tensile strength, which allowed it to be ripped instead of blasted. The bulk of the material dredged was a broken mixture of clay and sand with a few large pieces varying from 1 to $50 \mathrm{cu}$ yd. The smaller material was placed by precision dumping at sea to form a new crustacean habitat. Some of the larger blocks were used in selected areas to enhance seabed habitat, and small quantities were placed on the foreshore to improve stability of flood defenses.

United Arab Emirates. Rock is often dredged from harbor-deepening projects in Middle Eastern countries. During the construction of Jebal Ali Harbor, just outside of Dubai, limestone was encountered during dredging of the main channel. The limestone was blasted into small pieces and dumped offshore. Offshore dumping projects may provide insight to habitat that develops from bedrock placement.

New Zealand. In the New Zealand Port of Tauranga, the port authority recently completed a navigational channel improvement project that increased the width and depth of the main channel. Prior to dredging the existing channel, a reef, which lined one side of the existing navigation channel, had to be blasted and removed. This reef, consisting of rounded boulders of volcanic origin (rhyolite) buried in weakly cemented sand, was removed and relocated to another section of the harbor to mitigate lost habitat. The rock varied in size from 1 to $6.5 \mathrm{ft}$ in diameter, and a majority of it was ripped using heavy equipment, with only a small amount requiring blasting. The artificial reef was constructed by tipping the barges in a controlled manner with the intention of covering the steep sides of a harbor channel with a single layer of boulders. The new reef was constructed with dimensions of 130 by $1,000 \mathrm{ft}$. 


\section{Potential Beneficial Use Options for Dredged Bedrock}

Bedrock material has been used sparingly in beneficial use projects to date; however, dredged materials including sand, silt, mud, and clays have been implemented extensively. Utilizing these projects as a point of reference, it is possible to examine beneficial use options for bedrock material in the NY/NJ Harbor (Figure 1). There are significant options available to the USACE and their nonfederal sponsors for employing rock as a resource.

The best method for implementing agencies to examine these differing levels of feasibility is through screening level alternatives analysis. In this process, the factors that affect the environmental benefit and economic cost are researched and then evaluated to determine overall feasibility of project completion. During the process, information is generated with respect to planning logistics, environmental benefits, economics costs, constraints to successful implementation, and habitats for potential use. Table 2 presents the culmination of those studies in a brief summary. Detailed information regarding each potential use can be found in Chapter 3, "Beneficial Use Alternatives" and in Appendix B, "Overview of Beneficial Use of Dredged Bedrock: Issue Analysis." Each alternative is evaluated on potential use in the NY/NJ Harbor based on parameters including: preferential material type, potential volumes, preferential material size, optimal wave environment, and regional feasibility. 


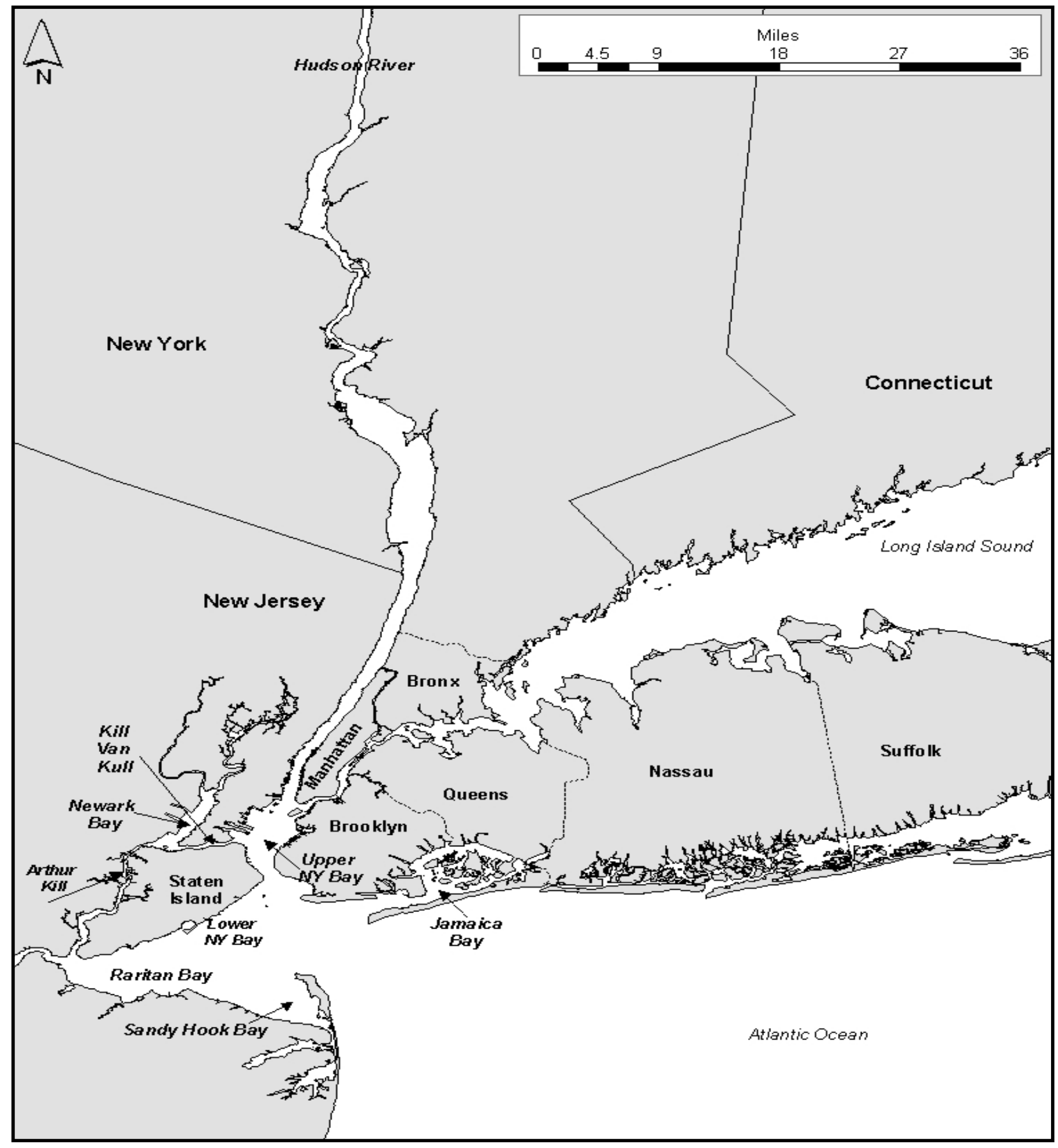

Figure 1. NY/NJ Harbor overview (Battelle 2002) 


\begin{tabular}{|c|c|c|c|c|c|}
\hline \multicolumn{6}{|c|}{$\begin{array}{l}\text { Table } 2 \\
\text { Potential Beneficial Uses of Dredged Bedrock }\end{array}$} \\
\hline $\begin{array}{l}\text { Beneficial Use } \\
\text { Option }\end{array}$ & Material Type $^{1}$ & $\begin{array}{l}\text { Potential Volume } \\
\text { cu yd }\end{array}$ & \begin{tabular}{|l} 
Material \\
Size $^{2}$
\end{tabular} & $\begin{array}{l}\text { Optimal Wave } \\
\text { Environment }^{3}\end{array}$ & $\begin{array}{l}\text { Feasibility } \\
\text { in NY/NJ } \\
\text { Harbor }\end{array}$ \\
\hline Artificial reefs & $\begin{array}{l}\mathrm{D}, \mathrm{S}, \mathrm{SH}, \mathrm{SA}, \\
\mathrm{O}\end{array}$ & $5,000-500,000+$ & L,M,S & L & High \\
\hline Oyster reefs & $\mathrm{SH}, \mathrm{SA}, \mathrm{O}$ & $500-20,000$ & $M, S$ & $\mathrm{~L}$ & Med \\
\hline Lobster reefs & $\mathrm{D}, \mathrm{S}, \mathrm{SH}$ & $1,000-40,000$ & $L, M, S$ & $\mathrm{~L}$ & Med-High \\
\hline Inshore reefs & $\mathrm{S}, \mathrm{SH}$ & $1,000-5,000$ & $\mathrm{M}, \mathrm{S}$ & $L, M$ & Low \\
\hline $\begin{array}{l}\text { Sediment feeder } \\
\text { material }\end{array}$ & $\mathrm{SH}, \mathrm{SH}, \mathrm{O}$ & $4,000-100,000+$ & $M, S$ & $\mathrm{M}, \mathrm{H}$ & Med-Low \\
\hline Groins \& jetties & $\mathrm{D}$ & $5,000-200,000$ & $L, M$ & $\mathrm{M}, \mathrm{H}$ & Med \\
\hline Revetments & $D, S A$ & $4,000-100,000$ & $\mathrm{M}$ & $\mathrm{M}, \mathrm{H}$ & Med \\
\hline Seawalls & $D, S A$ & $4,000-100,000$ & $L, M$ & $\mathrm{M}, \mathrm{H}$ & Low \\
\hline Breakwaters & $D, S A$ & $5,000-200,000$ & $L, M$ & $\mathrm{M}, \mathrm{H}$ & Med-High \\
\hline $\begin{array}{l}\text { Wave-attenuating } \\
\text { devices }\end{array}$ & $\mathrm{D}, \mathrm{SA}$ & $2,000-10,000+$ & $M$ & $M, L$ & Med \\
\hline $\begin{array}{l}\text { Aggregate } \\
\text { production }\end{array}$ & $\mathrm{D}, \mathrm{SH}, \mathrm{SA}$ & $10,000-750,000+$ & $L, M, S$ & $\mathrm{~N} / \mathrm{A}$ & High \\
\hline \multicolumn{6}{|c|}{$\begin{array}{l}\text { Note: Beneficial uses are rated based on information generated during the screening level analysis. } \\
\text { For example, artificial reefs are given a rating of high feasibility due to limited constraints to imple- } \\
\text { mentation. Material types available are all types of clean rock material, with potential volumes } \\
\text { exceeding } 500,000 \mathrm{cu} \text { yd. Inshore reefs are given a relatively low rating due to navigation and } \\
\text { infrastructure hazards that severely limit their use. Information regarding the decision-making } \\
\text { process can be found in Appendix C. Further information regarding individual uses can be found in } \\
\text { Chapter } 3 \text {. } \\
11 \text { Material type: Diabase (D), Serpentinite }(\mathrm{S}) \text {, Shale }(\mathrm{SH}) \text {, Sandstone }(\mathrm{SA}) \text {, Other (O). } \\
2 \text { Material size: Large }=>3 \mathrm{ft} \text { diam }(\mathrm{L}) \text {, Medium }=0.34-3 \mathrm{ft} \text { diam }(\mathrm{M}) \text {, Small }=<0.34 \mathrm{ft} \text { diam (S). } \\
3 \text { Optimal wave environment: High }(\mathrm{H}) \text {, Moderate }(\mathrm{M}) \text {, Low }(\mathrm{L}) \text {. }\end{array}$} \\
\hline
\end{tabular}




\section{Beneficial Use Alternatives}

\section{Overview}

To analyze the value of each beneficial use alternative, extensive information is required. This information provides decisionmakers with the inputs necessary for determining the applicability of each option in the NY/NJ Harbor. Using specific criteria allows project sponsors to identify the most viable alternatives. This chapter presents the in-depth research and analysis on the feasibility of beneficially using dredged bedrock for environmental and engineering projects. Employing the methods presented in Appendices B and C, each use is examined for its applicability to the NY/NJ region via a detailed screening level analysis that includes discussion of beneficial use overview, implementation logistics, constraints to implementation, potential habitat types for option, and additional information regarding the issues and research currently being explored.

The following beneficial use alternatives are covered in this chapter:

a. Artificial reefs.

b. Oyster, lobster, and inshore reefs.

c. Nearshore wave-attenuation devices.

d. Groin, jetty, and revetment construction.

e. Reduction of loss for salt marsh, mud flat, and shallow habitats.

f. Commercial sale of dredged material.

\section{Artificial Reefs (Recreational Fishing and Diving)}

\section{Detailed beneficial use description}

Artificial reef structures have historically been employed to enhance fishing activities. Currently, most coastal states and some U.S. territories, including Puerto Rico and the Pacific Islands, have artificial reef programs. Potential uses for artificial reefs include recreational fishing enhancement, habitat enhancement and creation, sport diver enhancement and access, designed surfing breaks, commercial fishing enhancement, marine reserves, and mitigation (National Marine Fisheries Service (NMFS) 2001). 
Results from a workshop held to elicit stakeholders' recommendations are presented in this chapter grouped by topic area.

December 19, 2001, Workshop Report on Artificial Reefs: Artificial reefs are a major component of the current plan for dredged bedrock use. A significant amount of rock is being used for artificial reef construction in northern New Jersey and western New York annually. However, as volumes in the respective reefs reach capacity, two issues need to be addressed. First, capacities must be determined for each reef within the state program. Second, the continued cost of transporting bedrock material to these sites must be analyzed. In addition, there are concerns based on the recreational focus of the program, regarding the general public's benefit derived from using bedrock in artificial reefs. NMFS has suggested that limiting consumptive fishing on USACE-developed reefs by designating them special fishery management areas will increase the overall habitat gain of the project.

Development of reefs beyond that of those currently used by the USACE includes 11 possible reefs in New York and 14 in New Jersey. In addition, reef coordinators are currently considering the development of a new reef 31 nautical miles offshore between New York and New Jersey. All of these reefs are able to accept varying amounts of material. However, there appears to be a lack of information regarding biological use and diversity for current species. To begin filling those data gaps, NMFS is designing a joint project with the USACE to measure habitat composition and dynamics. These studies will contribute to the success of future reefs both within and outside of the harbor.
The phases involved in developing an artificial reef include planning, design, construction, and management. One or more objectives should be clearly defined for artificial reef structures or programs such as providing recreational fishing opportunities or creating structures for sport divers. Socioeconomic, environmental, biological, and regulatory factors should be considered in determining objectives. In determining potential reef locations, the geological, hydrographic, and biological characteristics of the site should be examined. Reef design criteria should include practicality, effectiveness in achieving reef objective, reef configuration, reef profile, interstitial space, total surface area, and openness of reef materials (NMFS 2001). Typically, materials used to construct artificial reefs include secondary use and natural materials (e.g., construction debris, quarry or dredged rock, vessels) and manufactured reef structures (e.g., reef balls). The function, compatibility, stability, and durability of potential artificial reef materials should be considered. Effective artificial reef management requires an appropriate monitoring program that will provide the information necessary to ensure permit and regulatory compliance and assess performance, engineering, biological, fisheries, and socioeconomic aspects of the project. Negligence in these reef development phases may result in conflicts among user groups at the site,

the potential to overharvest targeted species, or damage to natural habitats (NMFS 2001).

Artificial reefs are currently located at 11 permitted sites in New York, and at 14 permitted sites in New Jersey (Figure 2). Providing increased recreational fishing opportunities is the objective of the NY Artificial Reef Plan, which also states that the state should be solely responsible for planning, siting, and building artificial reefs, and should be the sole recipient of any permits granted for artificial reefs (NYSDEC 1993). The objectives of the NJ Reef Program are "to construct hard-substrate "reef" habitat in the ocean for certain species of fish and shellfish, new fishing grounds for anglers and underwater structures for scuba 


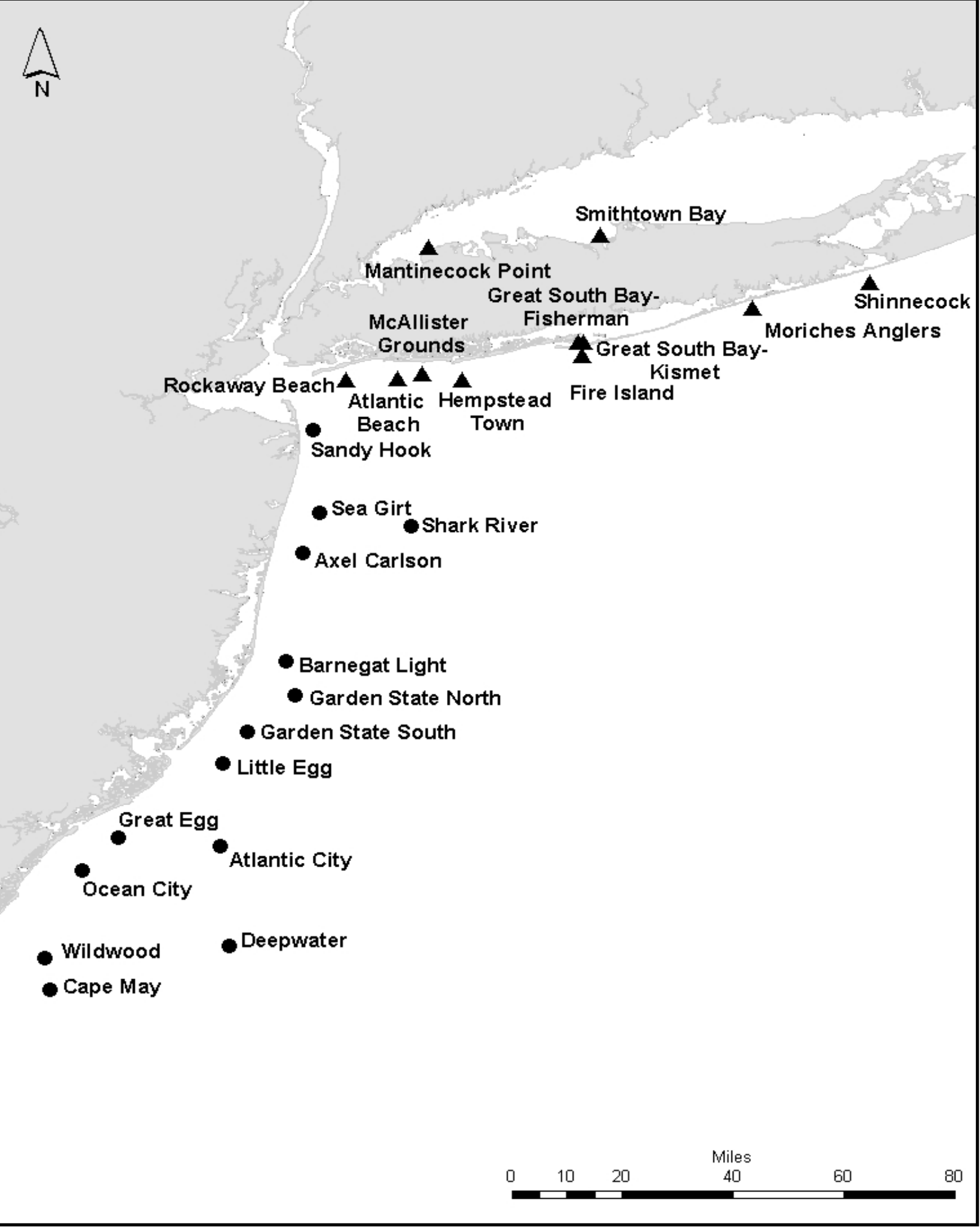

Figure 2. Permitted artificial reef sites in New York and New Jersey (New York State Department of Environmental Conservation (NYSDEC) 1993; New Jersey Department of Environmental Protection (NJDEP) 2001b) 
divers" (NJDEP 2001b). Any individual or organization can apply for a permit to construct an artificial reef in New Jersey; however, to date, only the state holds artificial reef permits (USACE 1999a).

Artificial reefs in New York and New Jersey have been constructed using a variety of material, including construction debris, dredged rock, vessels, manufactured reef structures, tires, and auto, train, and tank bodies. Such material is frequently offered to the reef programs, and the program coordinators evaluate the durability, stability, environmental safety, transportability, size, and composition of the material. ${ }^{1}$ Private individuals and organizations may donate material to artificial reef programs, and the reef program may support some of the costs involved with transporting the material to the reef site. Federal, state, and local governmental organizations may also donate materials to the artificial reef programs; the donating agency may be asked to share the cost of material transportation. For rock material, larger pieces are preferred; the material cannot contain more than 10 percent fines; and chip rock is not accepted. Typically, once a reef is created, its location is mapped and the water depth is determined. Side-scan sonar surveys are occasionally conducted to determine the profile of the structure. Comparing side-scan sonar images of the same structure over time can provide information about stability.

\section{Implementation logistics}

Each state's artificial reef program coordinates what materials are suitable for reef habitat establishment. Generally, when designing reef locations, coordinators prefer material of larger size spaced evenly about the seabed. However, in the past the reef programs have accepted a wide variety of material sizes and volumes. The program coordinator makes the final determination of a site's capability. A variety of design options for artificial reef structures are available. Reef configuration, reef profile, interstitial space, total surface area, and openness are all elements that should be considered. Site characteristics such as bottom composition and water depth also influence the design of the reef structure. The seafloor offshore of New York and New Jersey primarily consists of sandy planes, which are able to support the weight of reef structures.

The placement of the rock material is most simply achieved using a splitbottom barge, a process known as bottom dumping. Using any size of rock material will allow a reef structure to achieve relief, with flexible options for reef configuration and profile. The mounds of rock material achieved by bottom dumping could be conical mounds, or elongated ridges of material. The natural angle of side slope of dumped granular material should be about 33 deg. With a free fall of the material of a hundred feet, the actual side slopes will likely produce a slope approaching $20 \mathrm{deg}$. The number of barge loads dropped on a site, the

\footnotetext{
1 Personal communication, S. Heins, 2002, Coordinator, New York Artificial Reef Program, Bureau of Marine Resources, New York State Department of Environmental Conservation, communication with Amanda Bourque, http://www.dec.state.ny.us/website/dfwmr/marine/reefs00.html.

Personal communication, B. Figley, 2002, Fisheries Biologist, New Jersey’s Reef Program, Division of Fish and Wildlife, New Jersey Department of Environmental Protection, communication with Amanda Bourque, http://www.state.nj.us/dep/fgw/artreef.htm.
} 
precise location of the drops, the size of the material, and the depth of the water may influence the configuration and profile of the structure. Larger pieces of rock, however, will allow for increased interstitial space, total surface area, and openness, while maintaining options for configuration and profile. Igneous rock, such as that currently being generated in the NY/NJ Harbor, is preferred to sedimentary material for artificial reef creation because of the size, stability, and durability.

The goal of reef managers in New Jersey is to build expansive reefs in deep water, which propagates recreational opportunities. To optimize the habitat, the artificial reef programs build reefs based on specific criteria as follows: reef mounds are built 30 to $60 \mathrm{ft}$ high in a simple triangular prism shape with bases 170 to $330 \mathrm{ft}$ wide; the cross-sectional area of this reef is approximately 5,000 to $10,000 \mathrm{sq} \mathrm{ft}$; a diverse mix of rock sizes is dumped with interior voids expected to be approaching 25 percent. Off Long Island, the state of New York seeks to build reefs of smaller size, in shallower water. For a target footprint of 50 by $200 \mathrm{ft}$, a release of a full barge at $3,000 \mathrm{cu}$ yd will produce a triangular prismatic mound section with a height of about $16 \mathrm{ft}$, with a side slope of $32 \mathrm{deg}$. Since this structure would be at the limit of natural repose, a flatter slope of about $20 \mathrm{deg}$ is likely to develop, resulting in a larger footprint. Most likely, for the specified footprint, the required release volume would be 1,500 cu yd or one-half of a full barge load. In each case, the mounds must be in depths such that their crests have at least $30 \mathrm{ft}$ of water over them. With $30 \mathrm{ft}$ of navigable water, they provide adequate under keel clearance for recreational watercraft and smaller commercial vessels.

Artificial reef establishment is supported with material from multiple sources including private individuals and organizations. The artificial reef program may support some of the transportation costs to move the material to the location. Federal, state, and local governmental organizations may also donate materials to the artificial reef programs. In this case the participating agency may be asked to share the cost of moving the material to the site. In order to distribute the benefits and responsibilities associated with the construction of new reefs using dredged bedrock from specific projects, the reef programs in New York and New Jersey prefer to share the materials equally (S. Heins, NYSDEC, pers. comm.; B. Figley, NJDEP, pers. comm.). Due to the increased costs associated with transport of rock over longer distances, disposal efforts are likely to remain concentrated at the sites closest to dredging activities.

\section{Habitats and locations for projects}

The seafloor offshore of New York and New Jersey primarily consists of sandy planes, with occasional rock outcroppings. The vertical relief provided by an artificial reef structure can add to the complexity of an existing habitat, and may provide shelter, forage, nursery, migration, and/or spawning habitat for a variety of organisms, including fish and shellfish.

Fisheries management councils of the New England and Mid-Atlantic states (NEFMC and MAFMC, respectively) manage coastal and marine species occurring in the water of New York and New Jersey. They are required by the 
Magnuson-Stevens Fishery Conservation and Management Act (Sustainable Fisheries Act of 1996) to describe and identify essential fish habitat (EFH) in their respective regions. Congress defines EFH as "those waters and substrate necessary to fish for spawning, breeding, feeding or growth to maturity" (NMFS 2002). The species and life history stages for which EFH has been designated in the vicinity of the existing artificial reef sites in New York and New Jersey are summarized in Appendices E and F.

Understanding the habitat requirements of species potentially impacted by artificial reef creation will help to determine what environmental benefits can be derived in a specific area. Examining the habitat characteristics developed by the regional fishery management council enables the identification of relative species and their life history stages associated with reef structures (Northeast Fisheries Science Center (NEFSC) 2002). A recurring point of discussion among scientists and managers is the effect of artificial reefs on fisheries production. Natural populations may be reduced due to overfishing or other environmental effects, and recruits can be limited by forage and habitat availability. An artificial reef may concentrate remaining individuals, rendering them susceptible to fishing pressure. If habitat is limiting production, artificial reefs will promote production of new biomass by increasing the growth and survival of juveniles. Bohnsack (1989) reports that species most likely to benefit from artificial reefs are those with demersal, philopatric, territorial, and reef-obligate life histories. Those species in New York and New Jersey waters that may benefit from artificial reef habitat are presented in Table 3.

\section{Table 3 \\ Species Likely to Benefit from Artificial Reefs in New York and New Jersey ${ }^{1}$}

\begin{tabular}{|l|l|}
\hline \hline $\begin{array}{l}\text { New York and New Jersey EFH } \\
\text { Species with Rock or Reef Habitat } \\
\text { Preferences (NEFSC 2002) }\end{array}$ & $\begin{array}{l}\text { New York and New Jersey Species with Demersal, } \\
\text { Philopatric, Territorial, and Reef-Obligate Life } \\
\text { Histories (Bohnsack 1989; USACE 1999a) }\end{array}$ \\
\hline \hline American lobster (Homerus americanus) & American lobster (Homerus americanus) \\
Atlantic cod (Gadus morhua) & Atlantic cod (Gadus morhua) \\
Black sea bass (Centropristus striata) & Black sea bass (Centropristus striata) \\
Blue mussel (Mytilus edulis) & Blue mussel (Mytilus edulis) \\
Bluefish (Pomatomus saltatrix) & Cunner (Tautogolabrus adspersus) \\
Cunner (Tautogolabrus adspersus) & Rock crab (Cancer irroratus) \\
Gray triggerfish (Balistes carolinensus) & Tautog (Tautoga onitis) \\
Ocean pout (Macrozoarces americanus) & \\
Red hake (Urophycis chuss) & \\
Rock crab (Cancer irroratus) & \\
Scup (Stenotomus chrysops) & \\
Striped bass (Morone saxatilis) & \\
Summer flounder (Paralicthys dentatus) & \\
Tautog (Tautoga onitis) & \\
\hline \hline & As determined from EFH habitat descriptions and other life history characteristics. \\
\hline
\end{tabular}

Reef sites (Figure 2) are managed by the NY Artificial Reef Program (NYSDEC, Bureau of Marine Resources), and NJ Reef Program (NJDEP, Division of Fish and Wildlife). Existing reef sites in New York and New Jersey cumulatively cover approximately 2,500 and 21,000 acres, respectively. Esti- 
mated capacities of New York offshore reefs, totaling approximately 4.2 million cu yd are presented in Table 4. New Jersey reef sites are typically larger than New York reef sites (Table 4); capacities for New Jersey reefs have not been calculated, but are presumed to far exceed that required for current dredging project (B. Figley, NJDEP, pers. comm.).

Transportation costs may be a limiting factor for disposal sites distant from the origin of dredging, as they will raise the cost of the project per cubic yard. Currently, dredged rock is being deposited into the Sandy Hook, Shark River, and Atlantic Beach reef sites, which are the sites closest to the dredging activities. Approximately 25 percent of the Sandy Hook reef site is occupied with dredged rock structures and is considered overbuilt; disposal efforts in New Jersey waters are now primarily focused on the Shark River site (B. Figley, NJDEP, pers. comm.).

The New Jersey reef program envisions the construction of approximately three dozen high-relief structures, ranging from 30 to $60 \mathrm{ft}$ in height at the Shark River site, where water depths average $125 \mathrm{ft}$ (B. Figley, NJDEP, pers. comm.). New York preferences are for multiple smaller reefs constructed in a grid formation at multiple reef sites, with each reef structure containing approximately 3,000 to $9,000 \mathrm{cu}$ yd of material, occupying a footprint 50 by $200 \mathrm{ft}$ (S. Heins, NYSDEC, pers. comm.).

The New York artificial reef program has identified two potential sites where new reefs could be located. These sites (characterized in Table 5) were chosen primarily for their bottom stability, ambient biological productivity, and potential capacity (S. Heins, NYSDEC, pers. comm.). The proposed New York reef site has an estimated capacity of 3.6 million cubic yards and is closer to dredging operations than is the proposed deepwater site. Permits would be required to construct artificial reefs at both sites. Due to New Jersey's reef sites' large capability for material, New Jersey officials do not intend to develop any new artificial reef sites (B. Figley, NJDEP, pers. comm.).

\section{Oyster, Lobster, and Inshore Reefs}

\section{Oyster reefs}

Detailed beneficial use description. The American oyster, Crassostrea virginica, occurs in estuaries along the east coast of the United States, including the NY/NJ Harbor estuary. Oysters serve an important ecological function, improving water quality by filtering algae and sediments from coastal waters. In addition, oyster beds form reefs over time that provide habitat for a variety of fish and invertebrates. Oysters historically were the base of a significant commercial fishery in the NY/NJ Harbor. However, due to overfishing, disease effects, and 
Table 4

Characteristics of Artificial Reef Sites in New York and New Jersey

\begin{tabular}{|c|c|c|c|c|c|c|c|}
\hline Existing Reef Site & State & Location & \begin{tabular}{|l|} 
Distance from \\
Verrazano \\
Narrows, nm \\
\end{tabular} & $\begin{array}{l}\text { Area } \\
\text { acres }\end{array}$ & $\begin{array}{l}\text { Capacity }{ }^{1} \\
\text { cu yd }\end{array}$ & $\begin{array}{l}\text { Depth } \\
\mathrm{ft}\end{array}$ & Existing Material \\
\hline Rockaway Reef & NY & $\begin{array}{l}1.6 \mathrm{~nm} \text { south of } \\
\text { Rockaway Beach }\end{array}$ & 12 & 413 & At capacity & $32-40$ & $\begin{array}{l}\text { 3-tire units, steel buoys, rock, } \\
\text { construction rubble }\end{array}$ \\
\hline Atlantic Beach Reef & $\mathrm{NY}$ & $\begin{array}{l}3.0 \mathrm{~nm} \text { south of } \\
\text { Atlantic Beach }\end{array}$ & 19 & 413 & 240,000 & $55-64$ & $\begin{array}{l}\text { 3-tire units, vehicle bodies, } \\
\text { truck bodies, barges, vessels, } \\
\text { crane and boom, tanks, rock, } \\
\text { construction rubble }\end{array}$ \\
\hline $\begin{array}{l}\text { Fishing } \\
\text { Line/McAllister } \\
\text { Grounds Reef }\end{array}$ & NY & $\begin{array}{l}2.8 \mathrm{~nm} \text { south of Long } \\
\text { Beach }\end{array}$ & 22 & 115 & 63,000 & $50-53$ & $\begin{array}{l}\text { Construction rubble, steel } \\
\text { barges, vessels }\end{array}$ \\
\hline $\begin{array}{l}\text { Hempstead Town } \\
\text { Reef }\end{array}$ & NY & $\begin{array}{l}3.3 \mathrm{~nm} \text { south of Jones } \\
\text { Beach State Park }\end{array}$ & 27 & 744 & $1,656,000$ & $50-72$ & $\begin{array}{l}\text { Vessels, drydock, tanks, } \\
\text { barges, construction rubble }\end{array}$ \\
\hline Fire Island Reef & NY & $\begin{array}{l}2.0 \mathrm{~nm} \text { south of the } \\
\text { Fire Island lighthouse }\end{array}$ & 43 & 744 & $2,160,000$ & $62-73$ & $\begin{array}{l}\text { Tires, barges, vessels, } \\
\text { drydocks, tanks, coal ash } \\
\text { blocks, rock, concrete } \\
\text { cesspool rings, construction } \\
\text { debris }\end{array}$ \\
\hline Moriches Reef & NY & \begin{tabular}{|l|}
$2.4 \mathrm{~nm}$ SSW of \\
Moriches Inlet
\end{tabular} & 65 & 14 & 10,000 & $70-75$ & $\begin{array}{l}\text { Steel barges, vessels, tanks, } \\
\text { tires, dredge, concrete pipes } \\
\end{array}$ \\
\hline Shinnecock Reef & NY & $\begin{array}{l}2.0 \mathrm{~nm} \text { south of } \\
\text { Shinnecock Inlet }\end{array}$ & 79 & 35 & 50,000 & $79-84$ & $\begin{array}{l}\text { 3-tire units, barges, drydock, } \\
\text { vessels, steel and concrete } \\
\text { tower, tanks, construction } \\
\text { rubble }\end{array}$ \\
\hline \begin{tabular}{|l|} 
Great South Bay - \\
Kismet Reef
\end{tabular} & NY & $\begin{array}{l}120 \text { yards north of } \\
\text { beach west of Kismet }\end{array}$ & 44 & 10 & * & $16-25$ & $\begin{array}{l}\text { 3-tire units, barges, cement } \\
\text { blocks, construction rubble }\end{array}$ \\
\hline $\begin{array}{l}\text { Great South Bay - } \\
\text { Fisherman/ } \\
\text { Yellowbar Reef }\end{array}$ & NY & $\begin{array}{l}900 \text { yards east of the } \\
\text { Robert Moses fixed } \\
\text { bridge }\end{array}$ & 43 & 7 & * & $25-40$ & $\begin{array}{l}\text { Concrete reef balls, vessels, } \\
\text { concrete pipes }\end{array}$ \\
\hline $\begin{array}{l}\text { Smithtown Bay } \\
\text { Artificial Reef }\end{array}$ & NY & $\begin{array}{l}1.6 \mathrm{~nm} \text { WNW of Stony } \\
\text { Brook Harbor entrance }\end{array}$ & 50 & 3 & * & $38-40$ & $\begin{array}{l}\text { Tires, barges, concrete-filled } \\
\text { steel cylinders }\end{array}$ \\
\hline $\begin{array}{l}\text { Matinecock Point } \\
\text { Reef }\end{array}$ & NY & $\begin{array}{l}0.5 \mathrm{~nm} \text { north of } \\
\text { Peacock Point }\end{array}$ & 27 & 41 & * & $30-40$ & Undeveloped/unknown \\
\hline Sandy Hook Reef & $\mathrm{NJ}$ & $1.4 \mathrm{~nm}$ offshore & 13 & 1,187 & At capacity & $40-60$ & $\begin{array}{l}\text { Vessels, rock, concrete } \\
\text { rubble, tanks }\end{array}$ \\
\hline Sea Girt Reef & $\mathrm{NJ}$ & $3.5 \mathrm{~nm}$ offshore & 25 & 1,102 & * & $60-75$ & $\begin{array}{l}\text { Vessels, concrete rubble, } \\
\text { tanks, railroad cars, steel } \\
\end{array}$ \\
\hline Shark River Reef & $\mathrm{NJ}$ & $14.8 \mathrm{~nm}$ offshore & 32 & 610 & * & $119-128$ & Vessels, tire units, concrete \\
\hline Axel Carlson Reef & $\mathrm{NJ}$ & $2.1 \mathrm{~nm}$ offshore & 30 & 3,390 & * & $66-80$ & Vessels, tire units, tanks \\
\hline $\begin{array}{l}\text { Barnegat Light } \\
\text { Reef }\end{array}$ & $\mathrm{NJ}$ & $3.0 \mathrm{~nm}$ offshore & 44 & 720 & * & $46-58$ & $\begin{array}{l}\text { Vessels, tire units, tanks, reef } \\
\text { balls, steel }\end{array}$ \\
\hline $\begin{array}{l}\text { Garden State North } \\
\text { Reef }\end{array}$ & $\mathrm{NJ}$ & $6.5 \mathrm{~nm}$ offshore & 51 & 932 & * & $66-83$ & \begin{tabular}{|l|} 
Vessels, tire units, concrete, \\
tanks, railroad cars, reef balls
\end{tabular} \\
\hline $\begin{array}{l}\text { Garden State South } \\
\text { Reef }\end{array}$ & NJ & $5.1 \mathrm{~nm}$ offshore & 56 & 509 & * & $57-63$ & Vessels, tire units, tanks \\
\hline \begin{tabular}{|l|} 
Little Egg Reef \\
\end{tabular} & $\mathrm{NJ}$ & $3.8 \mathrm{~nm}$ offshore & 60 & 1,271 & * & $48-60$ & $\begin{array}{l}\text { Vessels, tire units, concrete, } \\
\text { tanks }\end{array}$ \\
\hline Great Egg Reef & $\mathrm{NJ}$ & $7.0 \mathrm{~nm}$ offshore & 75 & 932 & * & $47-70$ & Tire units, tanks \\
\hline Atlantic City Reef & $\mathrm{NJ}$ & $8.5 \mathrm{~nm}$ offshore & 73 & 3,390 & * & $55-94$ & $\begin{array}{l}\text { Vessels, tire units, tanks, } \\
\text { cable }\end{array}$ \\
\hline Ocean City Reef & $\mathrm{NJ}$ & $4.5 \mathrm{~nm}$ offshore & 82 & 678 & * & $53-66$ & Vessels, tire units, steel, tanks \\
\hline Wildwood Reef & $\mathrm{NJ}$ & $4.5 \mathrm{~nm}$ offshore & 96 & 1,780 & * & $40-63$ & $\begin{array}{l}\text { Vessels, tire units, concrete, } \\
\text { tanks }\end{array}$ \\
\hline Cape May & $\mathrm{NJ}$ & $8.5 \mathrm{~nm}$ offshore & 99 & 3,814 & * & $50-73$ & $\begin{array}{l}\text { Vessels, tire units, concrete, } \\
\text { tanks }\end{array}$ \\
\hline Deepwater Reef & $\mathrm{NJ}$ & $23 \mathrm{~nm}$ offshore & 88 & 610 & * & $90-125$ & Tire units \\
\hline
\end{tabular}




\begin{tabular}{|c|c|c|c|c|c|c|}
\hline \multicolumn{7}{|c|}{$\begin{array}{l}\text { Table } 5 \\
\text { Characteristics of Proposed Artificial Reef Sites in New York }\end{array}$} \\
\hline \begin{tabular}{|l|} 
Potential \\
New Reef \\
Site \\
\end{tabular} & State & Location & \begin{tabular}{|l|l} 
Distance from \\
Varrazano Narrows \\
Bridge, $\mathrm{nm}$ \\
\end{tabular} & $\begin{array}{l}\text { Area } \\
\text { acres }\end{array}$ & $\begin{array}{l}\text { Capacity } \\
\text { cu yd }\end{array}$ & Depth, $\mathrm{ft}$ \\
\hline $\begin{array}{l}\text { New York } \\
\text { Reef }\end{array}$ & NY & SE of Cholera Bank & 36 & 849 & $3,600,000$ & $81-97$ \\
\hline Deepwater & NY & South of Shinnecock Bay & 88 & 849 & $1^{1}$ & $124-138$ \\
\hline
\end{tabular}

reductions in water quality, oyster abundance in this area has declined dramatically over the past century.

Artificial oyster reef programs have been implemented in several locations in an attempt to reverse the long-term decline in oyster populations and restore the ecological benefit they provide. Successful artificial oyster reefs, such as those in the Chesapeake Bay and coastal Virginia, are characterized by being sited in areas of historical oyster abundance; the presence of diseaseresistant oysters may also contribute to the success of these reefs (Virginia Department of Environmental Quality (VDEQ) 2002). The NY/NJ Baykeeper has constructed pilot oyster reefs in NY Harbor near the Statue of Liberty and in Keyport Harbor, Raritan Bay (NY/NJ Baykeeper 2002).

Oyster veliger larvae prefer to settle out of the water column onto oyster shell, or cultch (Turner et al. 1994). To enhance settlement, the majority of artificial oyster reefs are constructed primarily using a combination of commercial by-product or fossilized shell from oysters and other shellfish species. However, because the supply of oyster and other types of shell is limited, other materials suitable for the construction of oyster reefs, such as dredged material, are of interest. Citing the limited success of a project in

December 19, 2001, Workshop Report on Oyster Reefs: Historically, oysters were a significant part of the NY/NJ ecosystem and a major food source until the early 20th century. Due to increasing pollution and decreasing water quality, oyster reef abundance has progressively declined. Oyster reefs have been implemented locally by a joint effort of NMFS and the NY/NJ Baykeeper. Several groups, including the Chesapeake Bay Foundation, are studying oyster reef design, which will enhance the understanding of oyster populations in the New York metropolitan area. The most important factor in successfully constructing these reefs appears to be the material on which the oysters are placed. Greatest success has been observed when the oysters are placed on oyster shell as interstitial spaces provide the optimal environment for larvae survival. The difficulty that arises with this method is that a limited supply of oyster shell and high costs make this approach economically infeasible. Engineering alternatives may provide lower costs.

Although studies are limited, the use of dredged bedrock would require using cobble-sized rocks with small interstitial spaces so as to provide larvae protection from predation. Using smaller, softer rock to create a tabletop type structure as a base when covered with 6 in. of shell appears to be a potential option. Water depth for any such structure should be close to intertidal for proper water exchange, which opens the possibilities for a combined nearshore breakwater/oyster reef application. In order to determine how to best construct reefs, a thorough analysis of existing oyster habitat location and material preferences in the NY/NJ Harbor needs to be performed. (Note: Attractive nuisance issues with the creation of large communities of oyster reefs may need to be addressed due to "poaching" of oysters.) 
Slaughter Creek, Chesapeake Bay, that involved capping a mound of dredged material with cultch, the USACE (1999a) identified artificial oyster reefs as a potential beneficial use for dredged material.

Implementation logistics. Artificial oyster reefs require very specific environment conditions, being both close to shore and of a relatively low profile. Additionally, oysters have shown a high preference for oyster shell habitat for reproduction and home site location. Oyster shell, however, is in short supply and consequently has very high associated costs. A solution that has been suggested is to create oyster habitat by covering dredged bedrock material with a thin veneer of oyster shell. This approach would require significantly less oyster shell for creation. However, the creation of oyster reef habitat as a beneficial use would be expected to utilize relatively low volumes of dredged bedrock, thus requiring a more focused resource approach to initiate construction.

Several physical characteristics must be considered in designing and siting an oyster reef. The smallest rock material sizes would be most useful in creating the core of the reef. Efficient placement of the outer cultch layer requires that the rock core of the reef has minimal interstitial spaces into which cultch could be lost. This may be difficult, however, due to diabase material being produced fracturing into large pieces that limit the creation of smaller interstitial spaces. In the NY/NJ Harbor, sandstone and shale may be preferable because of their abilities to naturally break into very small fragments requiring minimal mechanical effort. Care must be taken when making decisions to use such material so that placement does not occur in any area exposed to wave action that could mobilize core material.

Seafloor sediment must also be able to support the weight of the reef structure. Shell is much less dense than rock, and sediments able to support historical oyster beds may not be able to support a rock reef. Prevailing underwater currents may also easily transport the shell material. Adequate water circulation around the reef structure is important to the health of oysters and other reef-associated organisms. Siting a reef in areas where currents are present is important; however, excessive agitation may be detrimental to the reef stability. Oyster beds typically occur in shallow waters, and the Baykeeper's Keyport Harbor reefs were constructed in waters ranging from 2 to $7.5 \mathrm{ft}$ in depth. ${ }^{1}$ Considering potential tidal excursions, the reef could experience waves of $5 \mathrm{ft}$ or more in a severe storm, as well as potential boat wake height of $2 \mathrm{ft}$ or more. If a candidate site is otherwise suitable, but exposure is a concern, then some consideration to using other dredged material to "create" an environment around the periphery of the oyster reef should be considered. Very complex three-dimensional reef geometries could be created to direct tidal circulation, trap wave action, and maximize surface area of the reef available for settlement and habitat (USACE 1999a).

Standard scow sizes will be difficult to use to implement oyster reef habitat construction due to navigational draft requirements for deep-draft barges. Even at high tide, bottom dropping of material will be virtually impossible to accomplish in a controlled manner. A more probable construction means is flat deck barges,

1 Personal communication, F. Steimle, 2002, J. J. Howard Sandy Hook Laboratory, National Marine Fisheries Service, communication with Amanda Bourque. 
which have significantly shallower drafts, where the material would be bulldozed or washed over the side of the barge in a controlled fashion for deployment.

Establishing oyster populations on artificial reefs requires natural recruitment from other oyster beds, seeding the reef with cultured oysters, or a combination of both. The Baykeeper has conducted small-scale studies of natural recruitment that have found oyster larvae in many areas of the estuary, including the Hudson River. ${ }^{1}$ However, given that existing oyster populations in the NY/NJ Harbor are depleted (USACE 1999a; Iocco et al. 2000), natural recruitment is not likely to be sufficient to establish populations. Mature broodstock oysters can be purchased from culturists or transplanted from other oyster beds and placed on the reef to enhance production.

Alternatively, larger numbers of immature oysters can be used to seed the reef; these oysters will enhance production upon reaching maturity. The Baykeeper conducts an oyster-gardening program in which volunteers grow seed oysters at private locations (NY/NJ Baykeeper 2002). The volunteers are provided with juvenile oysters approximately $5 \mathrm{~mm}$ in length, and return the oysters to Baykeeper after 9 months, when they have approximately tripled in size. The gardened oysters are then used by Baykeeper to seed the reef at Keyport Harbor, and for various oyster-related research projects (F. Steimle, NMFS, pers. comm.). This type of project is important in developing public stewardship and providing educational opportunities, in addition to supplying the Keyport Harbor reef with seed stock. Similar procedures could be considered as part of an oyster restoration effort utilizing dredged bedrock material.

Construction of the oyster reefs needs to occur in relatively sheltered waters where good tidal circulation and water exchange occur. Primary candidate sites for oyster reef establishment are relic oyster beds. These sites need to be evaluated to determine the cause of degradation. An additional use of dredged material may be to sculpt a new topography that reduces the wave action and channels the currents in such as way so as to establish a nurturing environment. The volume of material used in this mode would exceed the limited volume of material required to create a flat relief oyster mound.

The volume of dredged material that could be utilized in the construction of artificial oyster reef is limited by water depth and by available open water area that can be designated as an artificial oyster reef site. The USACE (1999a) estimated that approximately 5,000 to 7,000 cu yd of dredged sediment would be required to create a 1-acre reef with a vertical relief of $3 \mathrm{ft}$. As rock material may undergo less compaction than sediment, a slightly smaller volume of rock material may be required to create a 1 -acre reef.

Additional costs are associated with oyster reef construction. The cultch layer must be purchased and planted. The cost of the cultch itself will vary depending on its source. The Virginia Oyster Heritage Program estimated that 10,000 bushels of cultch were required per acre to create a 10-in.-deep, twodimensional shell layer (VDEQ 2002). Creating a cultch surface layer over a

\footnotetext{
1 Personal communication, M. Stringer, 2002, NY/NJ Baykeeper Oyster Reef Restoration
} Program, communication with Amanda Bourque, http://www.nynjbaykeeper.org/. 
three-dimensional rock core is not equivalent to spreading a cultch layer over a two-dimensional surface. However, given that a cultch layer thickness of less than $10 \mathrm{in.}$ may be adequate (USACE 1999a), this estimate is appropriate for a reduced amount of shell required by a thinner cultch layer, and a greater amount required to cover a three-dimensional structure. While the rock for the core may be dumped directly at the site, the cultch layer would require greater care in placement.

Habitats and locations for projects. Choosing a reef site near areas of historical oyster abundance may mitigate some of the physical issues previously discussed. It is important to understand the reasons for the population decline; if any of those factors are still present in the area, recovery may be impeded. Water quality is improving in many areas of the estuary, and given appropriate habitat and a recruitment source, reestablishing some oyster populations may be achievable. Given these considerations, the most promising area for oyster reef construction is likely to be in western Raritan Bay, where the most significant oyster beds were historically located (USACE 1999a). Small oyster populations were found in the Bowery and Flushing Bays (Iocco et al. 2000), though it is uncertain if these areas could sustain population recovery where remnants of those beds may still remain (see Figure 3) (USACE 1999a).

Many areas of the estuary are closed for shellfish harvesting due to public health hazards. There are concerns among some members of the regulatory community that establishing large-scale oyster reefs will encourage harvesting of the oysters for consumption, regardless of the risk, which would require increased monitoring and enforcement of the reef sites and the markets where these oysters might be sold. Visible signage marking a reef, siting the reef in the vicinity of regular existing marine enforcement activities, and providing public education about the risks associated with consuming shellfish from impaired waters may help reduce the potential "attractive nuisance" of artificial oyster reefs.

\section{Lobster reefs}

Detailed beneficial use description. The American lobster, Homarus americanus, occurs in lower estuarine, coastal, and marine waters along the northeastern United States and Canada. The life history of the lobster includes a pelagic larval phase. Settlement cues, including temperature, trigger the postlarval lobster to settle out of the water column. Lobsters are shelter-preferring organisms, seeking refuge in rocky interstitial spaces or creating burrows in the mud. Shelter is especially important to juvenile lobsters, which are highly susceptible to predation. Given the commercial significance of the lobster fishery and potential exploitation of lobster stocks, multiple projects have focused on enhancing lobster populations by providing habitat. The "attraction versus production" debate discussed previously in the artificial reef section is also applicable to artificial habitat created to benefit lobsters.

Lobsters are known to be attracted to artificial reef structures. Scarratt (1968, 1973) found similar lobster size distribution and greater lobster biomass on an artificial quarry rock reef in eastern Canada compared with adjacent natural areas. 


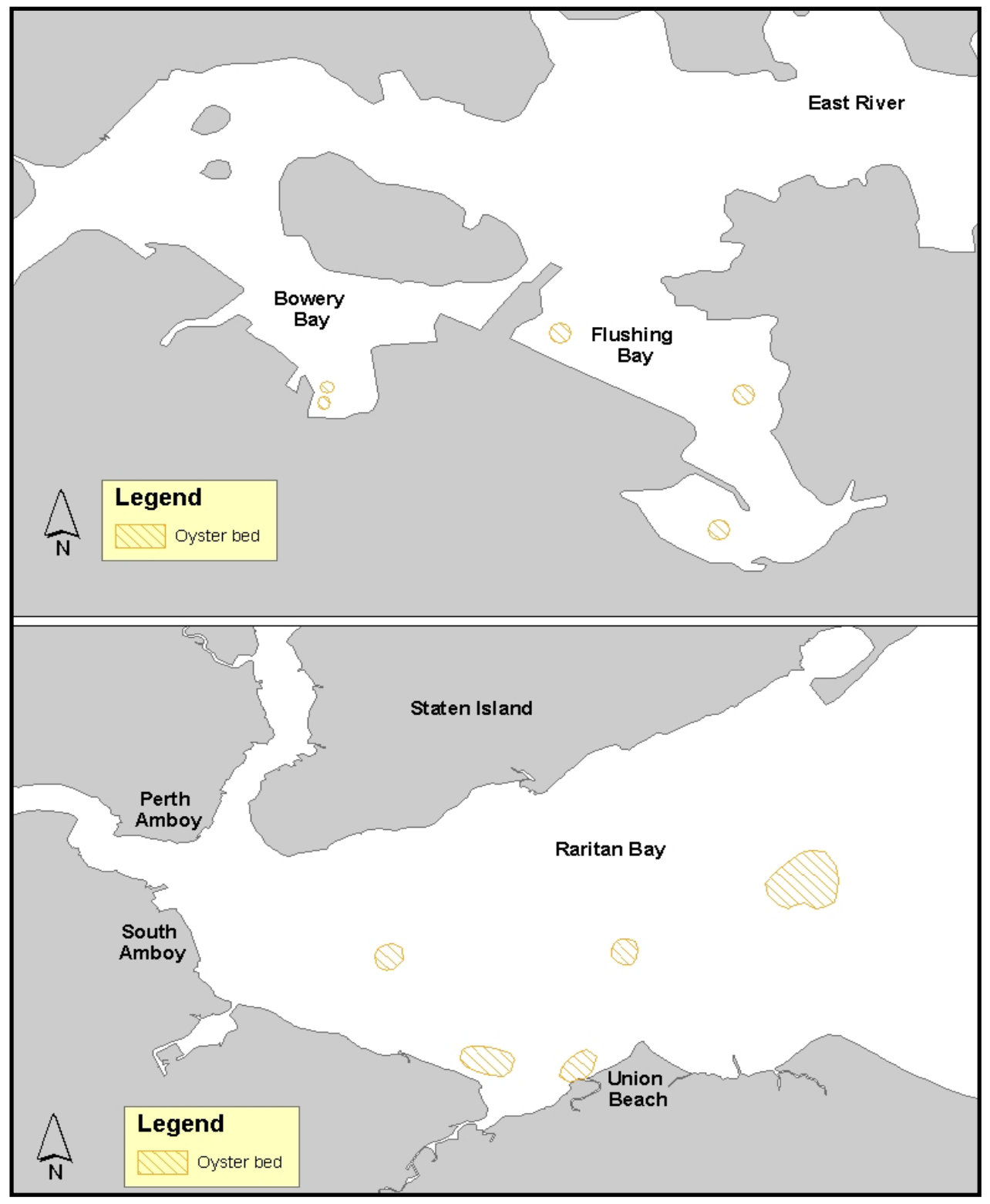

Figure 3. Location of existing artificial oyster reefs in the NY/NJ Harbor (NOAA 2002; USACE 1999a)

In a study involving shelters constructed from pumice stone in Rhode Island, Sheehy (1976) reported that more lobsters colonized shelters with three cavities than those with one cavity. Neither of these studies reported lobster recruitment at the artificial reef sites.

Evidence exists that lobster recruitment may occur on artificial reefs. At artificial reef sites in New Jersey, high densities (two to four lobsters per square foot) of juvenile lobsters (1 to 3 in. in length) have been observed (B. Figley, NJDEP, pers. comm.). The size of these juveniles and the distance of the reef site from other potential settlement areas may indicate that the juveniles settled at the site rather than walking in. Castro et al. (2001) describe artificial lobster reefs constructed on a featureless bottom in Dutch Harbor, Rhode Island, where lobsters 
both relocated and recruited to the reefs. The authors note that while increased production did occur at the reefs, conclusions cannot be drawn about the likelihood that those recruits would have successfully settled in other areas in the harbor, or the effect that recruitment at the reefs might have on the harbor population. Higher settlement was observed at the artificial reefs than at the natural rocky control site. The authors suggest that the reefs do not appear to have reached their carrying capacity because the uniformity of the cobble beds (and the associated interstitial spaces) provides greater protection from predation than the patchiness of shelter found at the natural rocky control site (Castro et al. 2001). The degree to which artificial lobster reefs may enhance lobster populations warrants further investigation. Increased production may be associated with larger projects, though whether or not production could be enhanced on a commercial scale is uncertain.

\section{December 19, 2001, Workshop Report on Lobster Reefs: Lobster reefs are another potential application for dredged bedrock. Lobsters, contrary to popular belief, are harvested from the NY Harbor with some regularity. In the region, an optimal material specification for the propagation of lobster reefs appears to be varying mixtures of cobblestone and clay. While lobsters in the New York metropolitan region may prefer habitat that is different from other lobster populations, it appears that cobble (for juveniles) and bedrock habitat can offer adequate protection. \\ Research is currently being conducted to determine the definitive habitat preferences in our ecosystem. Water depth may not be as significant a factor, because, historically, lobsters have been found in a variety of depths. To create an artificial reef for adult populations, water depth could be 30 to $80 \mathrm{ft}$ with a mixture of materials sizes including larger rocks 3 to $4 \mathrm{ft}$ in diameter. For juveniles, smaller rock at a shallower depth would be preferred.}

The lobster continues to thrive and is a large part of the commercial fishing industry in the region. Several studies have recently examined the home range requirements of lobsters in the NY/NJ Harbor, and their preferences are beginning to be understood. Adults and juveniles have been found to have different habitat requirements; adults generally prefer habitats of greater depths and the shelter of larger interstitial spaces. Juveniles are attracted to shallower, nearshore habitats, with relatively smaller interstitial spaces. This difference in habitat preference makes it difficult to construct a reef for the species without focusing on a single life stage.

Implementation logistics. A precedent for creation of artificial lobster reefs with bedrock material does not exist; however, the dredging and placement of bedrock has resulted in the indirect production of lobster habitat. This may constitute a beneficial use of rock material and understanding how rock material was managed in these cases can provide insight into how to create lobster habitat.

Lobster reefs can be separated into two different categories: juvenile and adults reefs. While the potential for creating reefs for both life stages does exist, it would need to factor in the preferences of both juvenile and adult lobsters. Adult lobsters prefer rock of relatively larger sizes, ranging from 3 to $4 \mathrm{ft}$ in diameter. This allows for more sizable interstitial spaces. Size estimates of an adult lobster reef could be similar to artificial fishing reefs that are $600 \mathrm{ft}$ apart and 200 by $50 \mathrm{yd}$ in size. For juveniles, rock size preferred is smaller, 1 to $2 \mathrm{ft}$ in diameter, creating more protection for larvae and young. Viable rock materials include most hard rock such as diabase and some mid to soft material. 
The volumes of material that could be used in the creation of a lobster reef will vary depending on the type of reef desired. A primary consideration for stable reef construction is that the sediment at the site be able to bear the weight of the structure. Several physical factors influence the recruitment of postlarval lobsters, and should be considered in designing an artificial reef intended to enhance lobster populations. Suitable habitat must be available to provide small shelters for juveniles. Reef-associated and reef-dependent fish species, such as black sea bass, tautog, and cunner, would also be expected to utilize habitat provided by an artificial lobster reef, and will prey on juvenile lobsters. Thus, the availability of small shelter spaces is essential. Cobbles have been successfully used to create artificial lobster reefs (Castro et al. 2001). Reefs at the Dutch Harbor site consisted of two abutting 10-m-square sections, containing cobbles ranging in size from 10 to $20 \mathrm{~cm}$, and from 20 to $40 \mathrm{~cm}$, respectively. The smaller size range provided habitat for juveniles; the larger size range accommodated juveniles as they mature, or larger individuals migrating in from other locations.

A reef will require an available larval supply for recruitment. Prior to settlement, postlarvae are concentrated in upper layers of the water column. Sea breezes are important in concentrating the postlarvae, which settle at higher densities where nursery habitats are oriented to receive prevailing wind. ${ }^{1}$ Orienting the artificial reef to receive prevailing winds may enhance settlement.

NMFS has identified two potential sites in the lower NY Harbor, between Hoffman and Swinburne Islands, and in northeastern Gravesend Bay, where artificial lobster reefs constructed from dredged rock material might enhance lobster productivity (Ludwig 2001). NMFS offers design guidance for potential reefs at these sites, based on the experimental Dutch Harbor reefs. Suggested rock size ranges are 3 to $20 \mathrm{~cm}$, and 20 to $40 \mathrm{~cm}$, to accommodate juvenile and larger sized lobsters. NMFS suggests that each reef consist of abutting sections of the two size classes. Placement could be achieved by emptying one full split-bottom barge load of each size class in adjacent locations, so the two mounds are abutting. Water depths at the two sites range from 17 to $30 \mathrm{ft}$, and NMFS suggests that a minimum relief of $50 \mathrm{~cm}$ is necessary to ensure that depositional processes will not bury the structures. The profile and capacity of each reef will also depend on volume of the barge.

Handling costs will be introduced if rock material must be presorted to obtain the size classes required by the project. However, if blasting and dredging technology can produce the appropriate sizes, sorting may not be necessary. The cost of transporting rock material will be relatively low for the two lower harbor sites, if the rock is transported directly from the dredging site. Transportation to any offshore locations will involve increased costs. The working water depths of the reef site allow for the use of bottom dump barge scows. The target size of the rock material is generally large enough to remain immobile even during severe storm activity. If necessary, these reefs can be capped with selectively larger sized material culled from the dredged rock since the volume requirement is small.

\footnotetext{
1 Personal communication, R. Steneck, 2002, Darling Marine Center, University of Maine,
} communication with Amanda Bourque. 
Habitats and locations for projects. Recruitment has been found to be highest in open coastal areas and is reduced in estuaries (Wahle 1993), implicating temperature, salinity, habitat availability, and predation. Two populations of lobsters are believed to occur in NY/NJ waters, an inshore population within the lower estuary, and an offshore population within the Hudson Canyon and offshore of Long Island. ${ }^{1}$ These two populations may provide a larval source for recruitment at artificial reefs in New York and New Jersey waters.

The NMFS proposed the two potential sites in lower NY Harbor for several reasons (Ludwig 2001). The sediments at these locations may be able to support the weight of rock reef structures. Lobsters presently occur, and were historically abundant along the lower Staten Island shoreline, suggesting that food and shelter requirements are present. Inshore rocky habitats in Gravesend Bay may be attractive habitat for lobster, and creating artificial lobster reefs in Gravesend Bay may replicate this habitat. NMFS plankton surveys in the NY/NJ Harbor have found relatively high numbers of lobster larvae in the area, indicating the potential availability of a recruitment source (M. Ludwig, NMFS, pers. comm.).

The NY Artificial Reef Program and NJ's Reef Program recognize that lobsters are targeted by commercial fishermen and sport divers (B. Figley, NJDEP, pers. comm.; S. Heins, NYSDEC, pers. comm.). Creating artificial lobster reefs at existing offshore reef sites in New York and New Jersey (see Figure 4) would likely enhance the opportunities for these user groups to catch and/or view lobsters. Constructing both estuarine and offshore lobster reefs might also afford the opportunity to compare the artificial habitat usage of inshore and offshore populations.

\section{Estuarine reefs}

Detailed beneficial use description. In the NY/NJ Harbor, shellfish beds historically occupied much of the estuary floor. Shellfish were important in maintaining water quality, and beds provided habitat for numerous fish and invertebrate species at different life history stages. Shellfish are filter feeders that improve water quality by filtration. Overfishing and degraded water qualities have removed shellfish beds from most areas in the estuary. Artificial rock reefs constructed within the estuary may contribute to restoring the habitat function historically provided by shellfish beds. Artificial reefs constructed specifically to benefit oysters and lobsters in estuaries are discussed in separate sections of this report.

Implementation logistics. Interstitial space, total surface area, and openness are characteristics that should be maximized. Multiple three-dimensional structures at a site will maximize surface areas and might alter local water circulation patterns, possibly enhancing local water quality. The USACE (1999a) calculated that the construction of a 1-acre estuarine reef with $3 \mathrm{ft}$ of relief would require approximately 5,000 cu yd of bedrock. Using rock of varying sizes will create a

\footnotetext{
1 Personal communication, M. Ludwig, 2002, Milford Laboratory, National Marine Fisheries Service, communication with Amanda Bourque.
} 


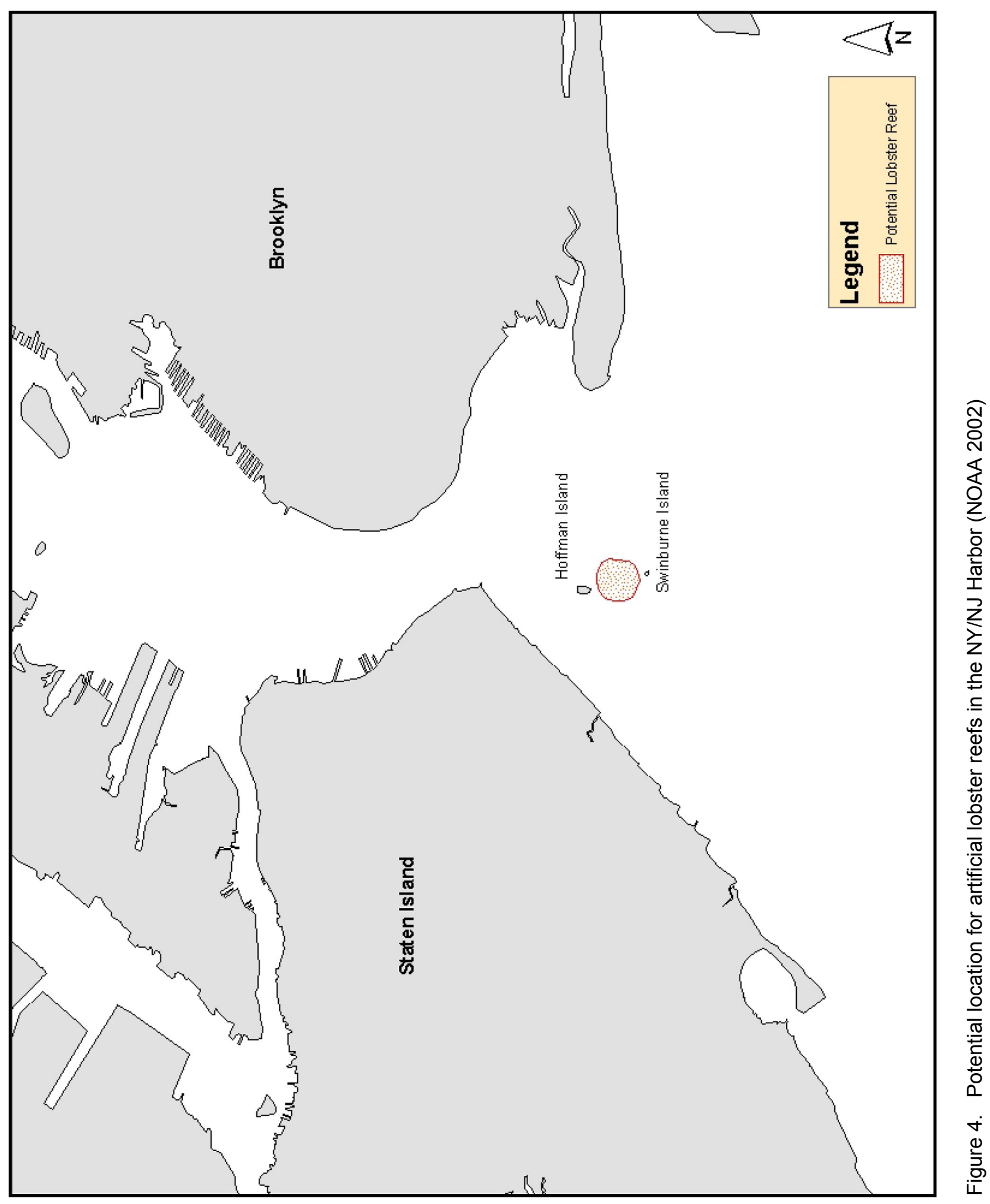


variety of interstitial spaces, including smaller spaces to provide habitat for juvenile fish found in estuarine nursery habitats. Shallow water depths within the estuary will influence reef design at each site. Maintaining navigational safety in the vicinity of artificial reefs within the estuary may be achieved by marking those reefs with limited clearance. Following the same principles as discussed for nearshore wave-attenuating devices (to follow), these structures can be made stable under various exposure levels. Designed and located, a system of estuarine reefs could perform a dual purpose of shoreline protection and habitat. In semiprotected waters of estuaries, it is generally not necessary to totally eliminate wave turbulence, or limit it, which is a natural behavior trait of a submerged reef. Construction of these reefs could not be accomplished using split-hull barge dumping methods, and more likely would involve offloading of rock from shallow draft barges or construction from land though the use of temporary causeways.

Habitats and locations for projects. Silty sediments that may not support the weight of a reef structure characterize many areas of the NY/NJ Harbor. Those areas with sandy bottoms and existing shellfish beds nearby may be areas in which an estuarine reef could replicate and extend the habitat provided by the shellfish beds. A review of benthic habitat maps for the upper (Iocco et al. 2000) and lower (NOAA 2002) bays of the estuary yielded several potential areas for siting estuarine rock reefs (Figure 5). A large portion of the Lower Bay and a smaller portion of eastern Raritan Bay are characterized by productive sands, including clam and mussel populations. The area of the Lower Bay to the east of Anchorage Channel is also sandy with clams and mussel beds, but is near two sand borrow areas and may be disturbed in the future. A few sandy patches are located in the North Reach of Newark Bay to the east of the shipping channel. Iocco et al. (2000) found no shellfish in Newark Bay, but refer to previous studies that report high abundance of clams. The shallow depths of Newark Bay might require any reefs built there to be scaled down in height. In Upper Bay, patches of shell bed and sandy sediments are located to the west of Anchorage Channel and near the mouth of KVK. Three potential sandy areas are located in Jamaica Bay. The northern and eastern areas are in close proximity to shipping channels, and thus the central area, which may be the largest of the three, is likely to be the most promising. A small oyster bed was found in the northwestern corner of Flushing Bay and is discussed earlier in this report as a potential site for oyster reef restoration. Bowery Bay is characterized by silty sediments. Further investigation of sediment types within the estuary may yield additional potential locations for estuarine reefs.

The USACE (1998) identified data gaps for several biological groupings in many areas of the estuary. Many of the studies describing the fish, ichthyoplankton, macroinvertibrates, shellfish, meiofauna, zooplankton, and phytoplankton of the estuary were conducted during the 1980s; recent data are minimal. Detailed information about these biological groupings should be collected as part of the site-selection process for any oyster, lobster, and estuarine reef. These data will be important in choosing sites that will best achieve the objective of the reef while minimizing impacts to existing resources in the area, such as by covering existing shellfish beds or by disrupting seasonal fish migrations. 


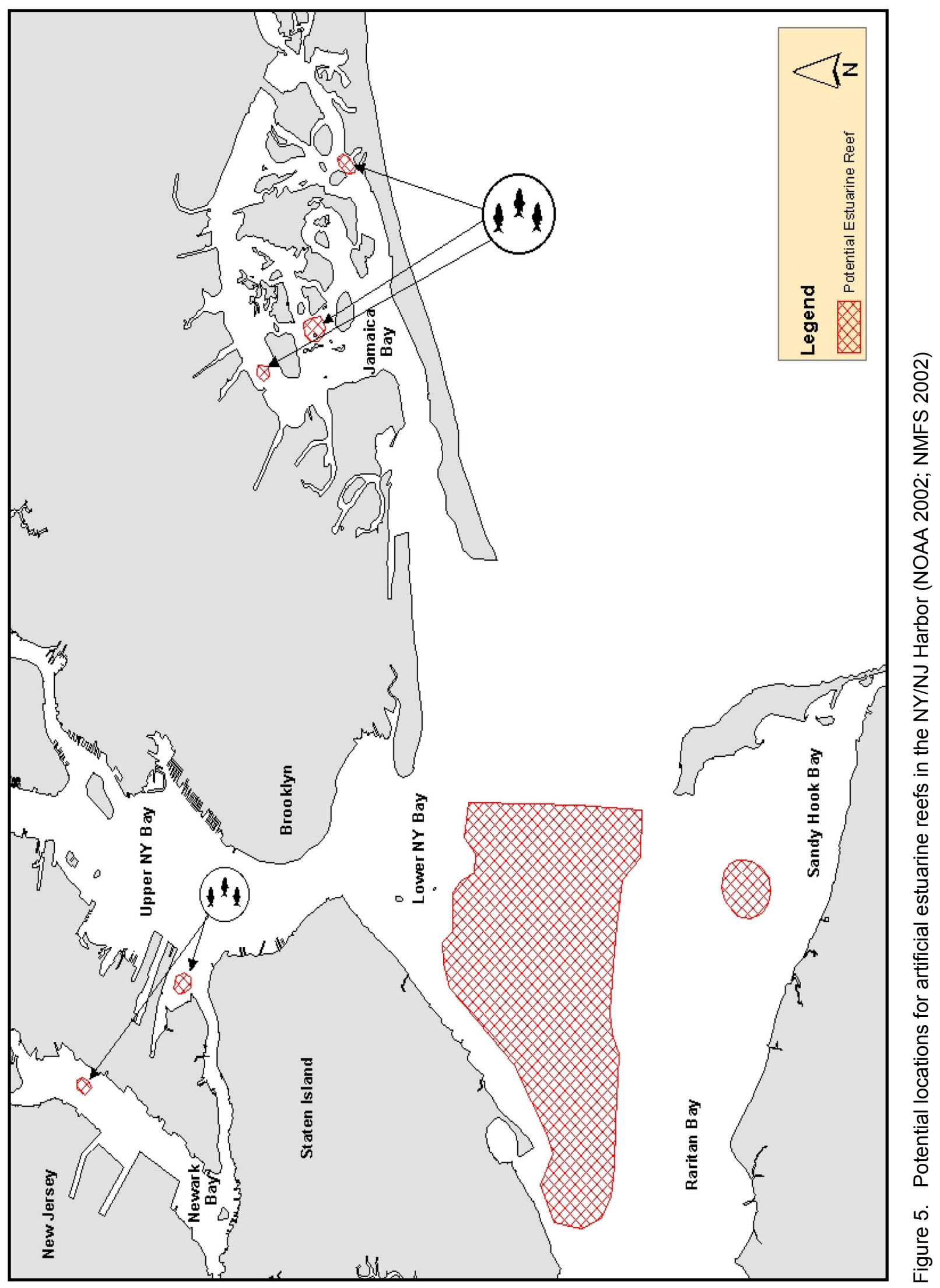


New research on habitat restoration may have relevance and be applicable to beneficial use projects in the estuary. For example, a project in the Chesapeake Bay is experimenting with alternative materials and stock enhancement by constructing reefs of limestone rock upon which oyster spat have previously been settled. This idea could be applied to the oyster reefs discussed in this report (Mike Stringer, NY/NJ Baykeeper, pers. comm.). Larvae could potentially be settled on oyster shells prior to placement of the shells over the rock core of the reef.

\section{Nearshore Wave-Attenuation Devices}

\section{Detailed beneficial use description}

Nearshore wave-attenuation devices can protect coastal habitats subject to frequent wave action by using principles employed by breakwaters and groins. An example of habitats that could be protected by these structures includes salt marsh, wetland, and other estuarine systems that experience loss of habitat. The loss of habitat can be caused by several types of forces such as natural waves, boat wakes, and slope failure in dredged channels. The structures would be constructed within 5 to $15 \mathrm{yd}$ of the shoreline and would serve two functions. The first function that the nearshore wave-attenuation device would address is that of wave action. Each structure would significantly cut down the amount of wave energy that reaches the shore. Secondly, the structure would function as a mechanism for trapping sand and silt material behind the device to build up and create increased marsh habitat.

December 19, 2001, Workshop Report on Nearshore Wave-Attenuation Devices: This concept may be very pertinent to protecting and reducing the loss of salt marsh, mud flat, and shallow water habitats prevalent in our region. In this scenario, bedrock material would be placed parallel to the shore to provide a buffer between the structure and the shoreline. Implementing this option would both protect the shoreline and allow for the accretion of material between the structure and the shore. However, it is important that the nearshore topography be evaluated as to limit the degradation of preexisting slope imbalances. Rock type and size are critical to the success of this structure. Potential sites where this may be utilized include Jamaica Bay, KVK, AK, Port Monmouth, and Raritan and Sandy Hook Bays.
Nearshore wave-attenuating devices can be used to limit the wave energy reaching a shoreline. Each system is tuned to establish a certain amount of wave attenuation with an associated shoreline response. These structural systems are frequently installed in water depths commonly ranging from 6 to $20 \mathrm{ft}$ and need to function and survive in a wave height environment that may equal the depth of water. The primary function of such systems is to reduce beach erosion, though the systems might provide secondary functions ranging from public access structures to marine habitat.

Sea level rise is also a concern of coastal engineers. One strategy for protecting vulnerable coastal areas is to armor them. Edgerton (1991) states "planners will have to choose among three basic options: (1) stabilizing the shoreline by erecting walls (hard stabilization); (2) raising the land and nourishing the beach with added sand (soft stabilization) or (3) allowing the shoreline to 
retreat and adapting to it." This illustrates the alternatives-based decisionmaking that may need to be addressed for coastal solutions.

Nearshore wave attenuators are most often shore parallel breakwaters or breakwater segments, but may also be configured as " $T$ " formations connecting with shore to form beach pockets and artificial headlands. Variations on the submerged breakwater concept including arrangements to join systems together can work to achieve optimal shore protection. Breakwater systems may require material that is larger and more durable, depending on the intensity of wave action in the desired area of development. Historically, breakwaters have been used in areas of higher wave action. For the different types of breakwaters, there is the potential for different uses of the material. Breakwaters typically have an inner "core" of smaller material that functions to block the transmission of wave action, surrounded by larger "armor" stone for the exterior, which holds the core from eroding away. Submerged breakwaters function somewhat uniquely in only reducing the largest of waves, allowing the less energetic waves to reach the shore. This allows some degree of natural shoreline process to occur, while protecting from the worst storms. Submerged breakwaters offer many benefits in terms of aesthetics, but also can be a navigation risk.

The bedrock type preferable for this type of structure would be medium to large size material, though there is opportunity to also use smaller material as fill for the structural core. Highly abrasive, fracture- and weather-resistant material is needed for construction to endure the ravages of a harsh environment. Generally, only diabase material being dredged from the AK and KVK channels possesses suitable performance properties, although if any of the sandstone has metamorphosed into quartzite, it too could be used.

The feasibility of using bedrock for construction of wave-attenuation systems in the New York area is ultimately determined by the accessibility of the site. Dredged rock offers the advantage of already being on a barge, but the disadvantage of being an unsorted, uncontrolled mass. The dredged rock on a barge also offers the advantage of being unhampered by road access required for landbased construction, but may be limited by water depths and exposure to weatherrelated hazards. The exception to this scenario would be when split hopper dredges could be positioned over the location of breakwater development, allowing for rock placement to create the core of a breakwater, or, in some instances, complete, submerged breakwaters.

Cost benefit would have to be determined and demonstrated on a site-specific basis to justify this application. The material would still need to be sorted or capped with larger rock to prevent shoreward migration, adding additional costs. With breakwaters located very near shore, the material would have to be either placed on a shallower draft barge or transferred to land-based tools for development. Material may need to be sorted to create the proper engineering characteristics. Further, if the design of the attenuating device relies on the use of the unsorted rock mix directly, the cost of this different design section must be compared to a conventional design to address the total cost of the opportunity, not just the differential costs of hauling and handling. 
The rock volumes this beneficial use would require depend heavily on the extent to which the wave-attenuating device extends. Assuming a structure $20 \mathrm{ft}$ high, crest width equaling $20 \mathrm{ft}$, and $2 \mathrm{H}: 1 \mathrm{~V}$ side slopes, with 25-percent voids, an estimate of required volume is $30 \mathrm{cu}$ yd per foot of structure. Depending on the length of coverage required for the shoreline, the total required volume might range from 10,000 to $100,000 \mathrm{cu}$ yd. Material size needed for the construction of higher impact sections of the structure are generally larger than material that will be produced by the current dredging and blasting of the KVK and AK. Therefore, material from this dredging project will most likely be used for core stone in any structures that are constructed from this project.

\section{Implementation logistics}

There are two approaches to creating a stable rock mass able to resist the erosive forces of waves. A rubble mound can be constructed as a series of lifts or layers, with each layer characterized by increasing sized material, each being progressively more resistant to wave attack. The mound can also be formed from an amorphous mass of rock, or zones of rock of more widely variable piece size, and generally allowed to conform to the wave environment. The former is called layered, or conventional, design while the latter is referred to as berm design.

Layered (conventional) design. The Hudson Equation for layered rock stability determination can be reverse analyzed to determine what size rock will be stable for what wave environment. For a cubic-shaped rock (USACE 2002):

$$
L^{3}=\left(H^{3}\right) / K_{D}\left(S_{r}-1\right)^{3} \cot \theta
$$

where

$$
\begin{aligned}
L^{3} & =\text { wave length cubed } \\
H^{3} & =\text { design wave height cubed } \\
K_{D} & =\text { stability coefficient } \\
S_{r} & =\text { specific weight of armor unit relative to water }
\end{aligned}
$$

Assuming $S_{r}$ is 2.62 in seawater, $K_{D}=4$, and a typical constructed slope angled $2 \mathrm{H}: 1 \mathrm{~V}$, then $L \cong H / 3$. For a spherical shape, $L \cong 0.4 H$, and for a prismatic shape $3 L \times L \times L, L \cong H / 5$, and $3 L \cong 0.6 H$. More generally, Ahrens (1988) gives stability of rock as a function of the ratio of both wave height and wave length. That relationship can be written in terms of rock size as:

$$
N_{s}=\left(H_{m 0}^{2} L_{p}\right)^{1 / 3} /\left[d_{50}\left(\rho_{r} / \rho_{w}-1\right)\right]<7 \text { (for cuboids) }
$$

where

$$
\begin{aligned}
N_{s} & =\text { stability number } \\
H_{m 0} & =\text { wave length of zeroth moment }
\end{aligned}
$$


$L_{p}=$ wave length calculated from period of peak energy density

$d_{50}=$ diameter of rock at $50^{\text {th }}$ percentile of stone size gradation

$\rho_{r}=$ unit density of rock

$\rho_{w}=$ unit density of water

Using the same rock parameters, and assuming a local wave steepness $(H / L)$ of $1: 25$, then $d_{50}$ is approximately $0.2 H_{m 0}$. From the range of values in these simplified calculations, it appears that the blasted rocks will generally be stable in waves which do not exceed roughly a third to 40 percent of their characteristic dimension, e.g., a rock of 1-ft characteristic dimension placed in a layered construction would be suitable for a wave environment up to $3 \mathrm{ft}$ in height.

Berm design. As previously computed, and as given by the Construction Industry Research and Information Association (CIRIA) (1991), the typical range for stable layered breakwaters is for $H / \Delta D$ to be in the range of 1 to 4 (when $\Delta$ is the relative mass density of the stone in water $\left(\rho_{r} / \rho_{w}-1\right)$ ). Berms will be stable for $H / \Delta D$ in the range of 3 to 6 , which allows for the use of somewhat smaller armor rock, or 50- to 100-percent larger waves, but at the expense of requiring a greater volume of material. Broadly, all shoreline structures follow this same trend as illustrated in Figure 6.

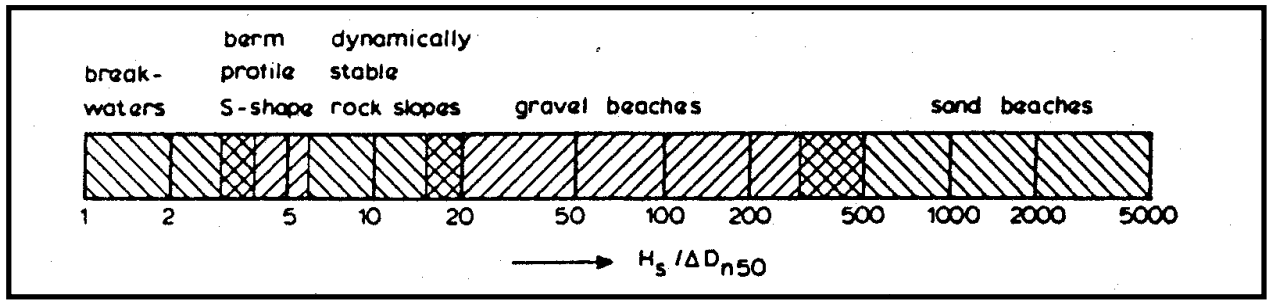

Figure 6. Type of structure as a function of $H_{s} / \Delta D_{n 50}$ (where $D_{n 50}=$ normal diameter of $50^{\text {th }}$ percentile rock on stone size gradation curve ) (van de Meer and Pilarczyk 1987)

Using the previous stability discussions and observations of produced rock size, emergent breakwater structures or offshore berms could be constructed using the largest material culled from the production, for significant wave sizes on the order of $12 \mathrm{ft}$ if constructed as a layered design, or perhaps as large as $20 \mathrm{ft}$ if constructed in a berm design.

Submerged structures are also an option as they are more stable in the large waves and also aesthetically preferable since they are largely invisible. However, they can only attenuate a percentage of the wave energy, dependent on the depth of submergence, anywhere from 20 to 50 percent (CIRIA 1991). This may be acceptable since smaller rock is being produced more abundantly and could be used to build underwater reefs, provided the wave environment ultimately reaching the shoreline is reduced to a tolerable level. They may be constructed similarly to a conventional armored breakwater, or as a mound. An estimate of the stability of rock mound at the initiation of damage, placed in a submerged condition, can be shown to be given by: 


$$
h / D=(2.4) \exp \left(-0.14 N_{s}\right)
$$

where

$$
\begin{aligned}
& h=\text { height of the mound } \\
& D=\text { water depth (CIRIA 1991) }
\end{aligned}
$$

Ahrens (1988) found that, practically, a submerged mound stabilized to a height equal to approximately 70 percent of the water depth of the design event. Figures 7 and 8 summarize the various styles of deformable and nondeformable rubble breakwater structures.

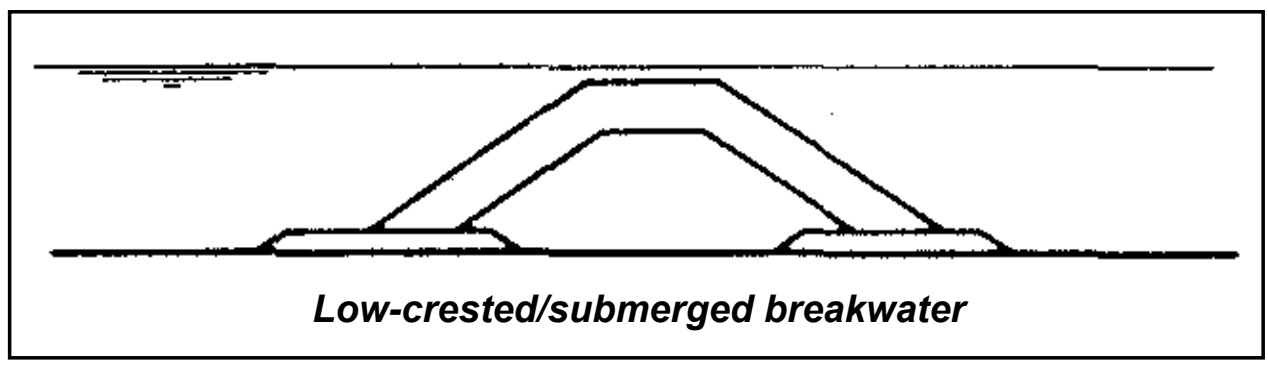

Figure 7. Nondeformable rubble structures (CIRIA 1991)
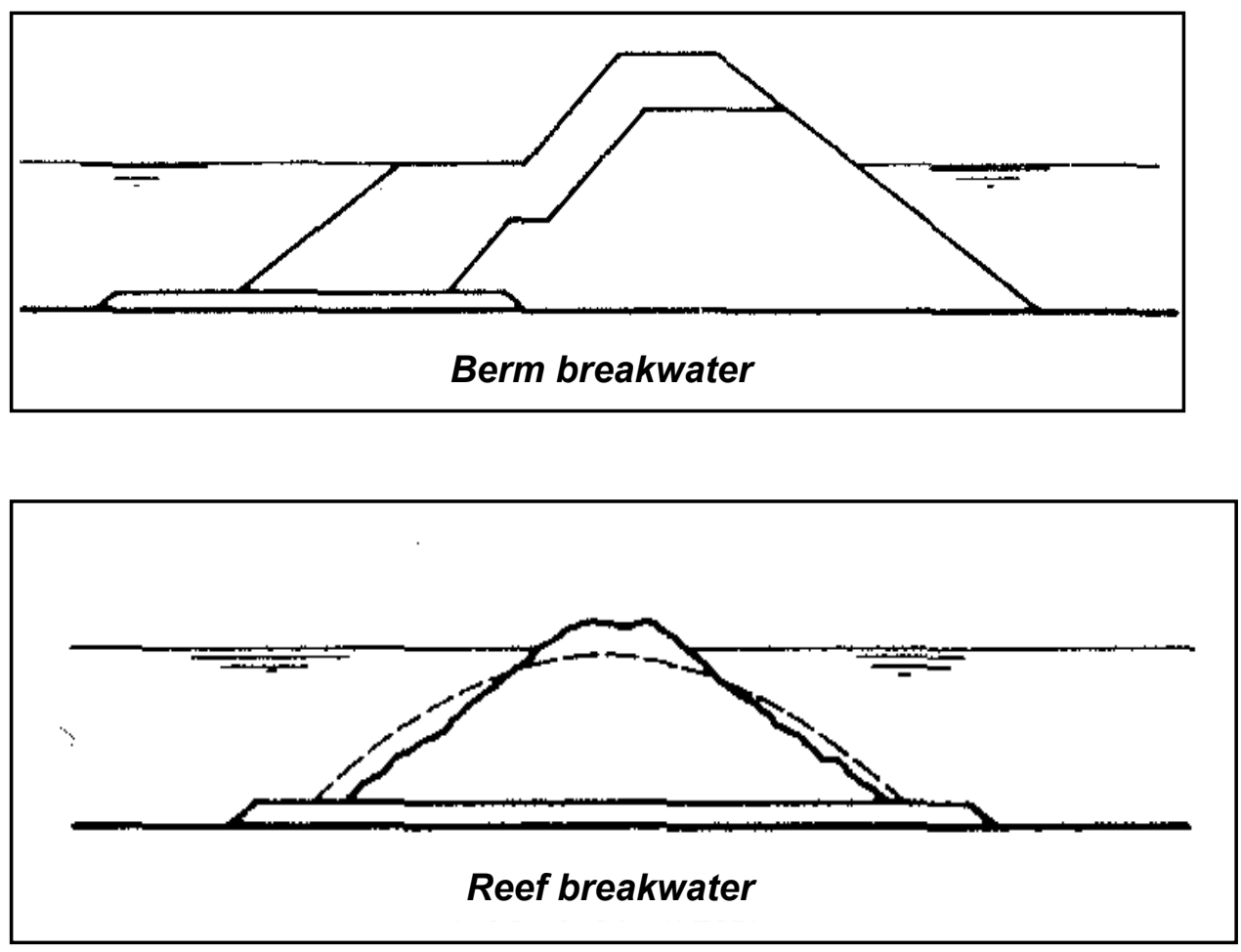

Figure 8. Deformable rubble structures (CIRIA 1991) 
The required size of a breakwater to achieve the desired wave attenuation can generally be determined from the wave transmission curve shown in Figure 9 and is primarily a function of the structure crest height. In actual design practice, this height requirement is a function of the specific structure geometry and composition. For example, berm breakwaters are not necessarily as tall as conventional breakwaters, but are much wider. Composite slopes, or other geometric features built into the breakwater face, can also affect the overtopping amount. Porosity of the structure will also affect its transmission. However, for the purposes of rough estimation or structure requirements, Figure 9 is a reasonable indicator.

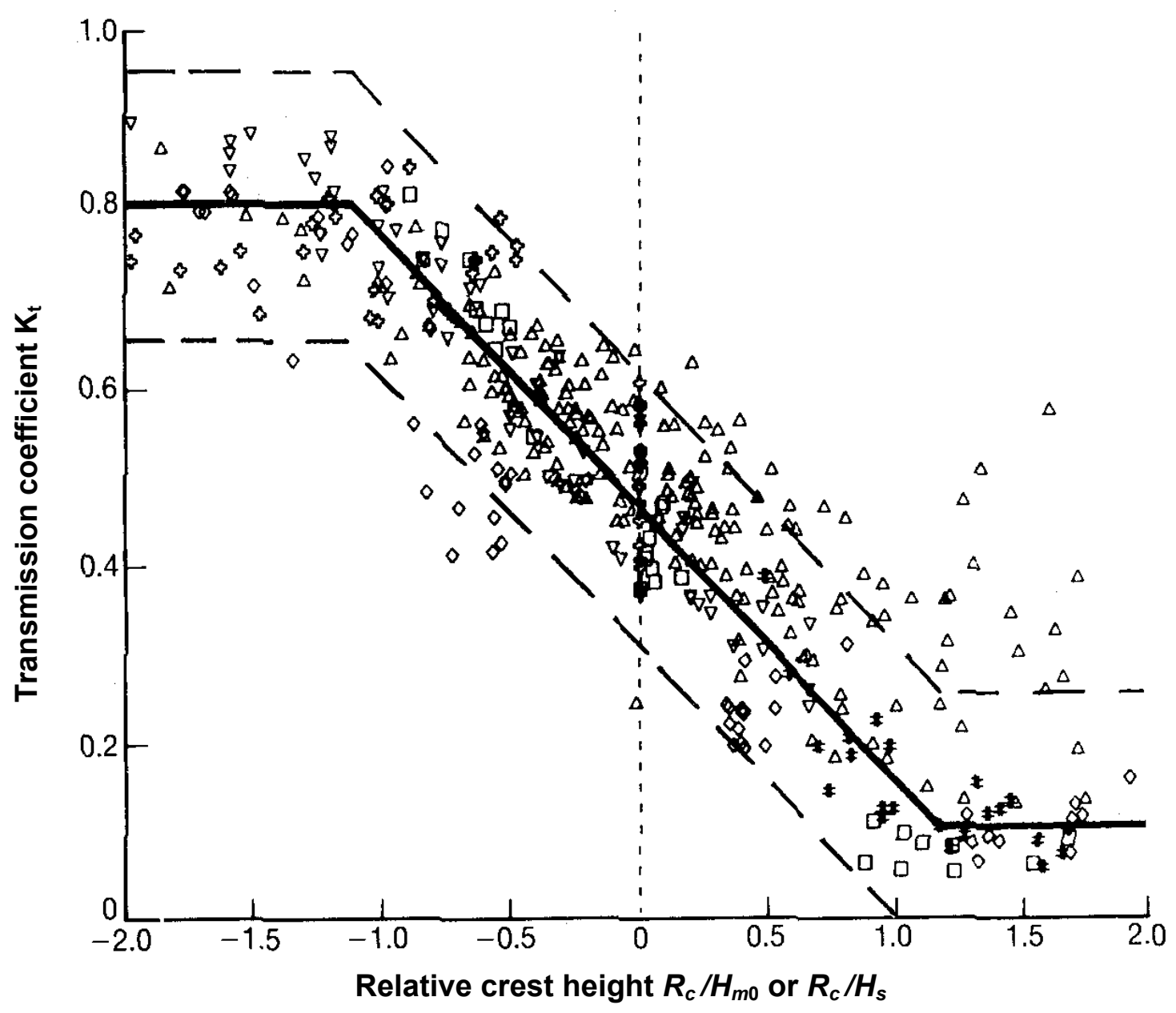

Figure 9. Wave transmission over low-crested structures (where $R_{c}=$ rest elevation above still water level or above substrate; $H_{s}=$ significant wave height) (CIRIA 1991)

While there is no specific threshold for wave height that induces erosion, it can be estimated that incipient erosion of sandy material occurs when waves reach approximately $0.7 \mathrm{ft}$ in height ( $T=3 \mathrm{sec}$, where $T$ is the wave period of monochromatic wave), and coarse-grained or consolidated material when wave height reaches $2.4 \mathrm{ft}$ (USACE 1996). Picking a nominal desired transmitted wave height for erosion control to be $1 \mathrm{ft}$, then an allowable transmission coefficient for a structure in semiprotected waters $(H<4 \mathrm{ft}$, where $H$ is the wave height of 
monochromatic wave) would be 25 percent, and on totally exposed shorelines $(H>10 \mathrm{ft})$ would be less than 10 percent. The figure then indicates that the height of structures in the semiprotected sites will be approximately 75 percent of the wave height, or $3 \mathrm{ft}$, while in exposed locations the required structure height will be at least $15 \mathrm{ft}$. The benefits of submerged structures can be assessed similarly. However, as mentioned earlier, their attenuating capacity ranges from 20 to 50 percent; therefore, depending on the situation, they may be applicable as stand alone, or may need to be used in combination with other protective means.

Minimum material sizes. The bedrock type that is preferable for submerged attenuation devices would be medium to medium-large size material. Due to the shallow positioning of this device, larger rock material could become a hazard to the navigational and recreational users. The structure may be stabilized with pilings constructed of wood/composite material to prevent the migration of the smaller material from its intended location or placement. This would require further engineering and modeling to study the impacts of variations on the design of the structures with respect to longshore transport. The volumes this beneficial use would require depend heavily on the extent to which the wave-attenuating device extends. Initial estimations would require about 3,000 to 5,000 $\mathrm{cu}$ yd to begin a project. Larger systems could approach $10,000 \mathrm{cu}$ yd.

\section{Habitats and locations for projects}

Five shoreline areas have been previously identified as being possible candidates for wave-attenuating structures: AK, Port Monmouth, Spring Lake, Monmouth Beach, and Raritan and Sandy Hook Bays. Selected sites are characterized in Table 6 or shown in Figure 10. They range in size, accessibility, and exposure.

\begin{tabular}{|c|c|c|c|c|}
\hline \multicolumn{5}{|c|}{$\begin{array}{l}\text { Table } 6 \\
\text { Site Characterizations }\end{array}$} \\
\hline Location & Project Size & Site Exposure & Protection Method & Material Suitability \\
\hline $\begin{array}{l}\text { Monmouth Beach, } \\
\text { NJ }\end{array}$ & $2000 \mathrm{ft}$ & High & Submerged breakwater & Berm or core material \\
\hline Spring Lake, NJ & $2000 \mathrm{ft}$ & High & Breakwater/groin & Berm or core material \\
\hline Port Monmouth, NJ & 2 miles & Moderate & Detached breakwater & Full structure \\
\hline Raritan Bay, NJ & 2 miles & Moderate & Detached breakwater & Full structure \\
\hline
\end{tabular}

Wave-attenuating systems are being considered for various locations around the shores of Sandy Hook and Raritan Bays. The primary locations for erosion control structures are the Union Beach, Keyport, and Highlands areas. The Union Beach protection scheme, already developed, calls for a fairly robust structure, requiring armor stone weighing several tons. Highland and Keyport are somewhat more protected, allowing for the potential use of material sized less than a ton. Given the present size of produced material from the dredging operation, the Union Beach project could generally only utilize product for underlayer and bedding material. Approximately 25,000 cu yd of durable material is required. 


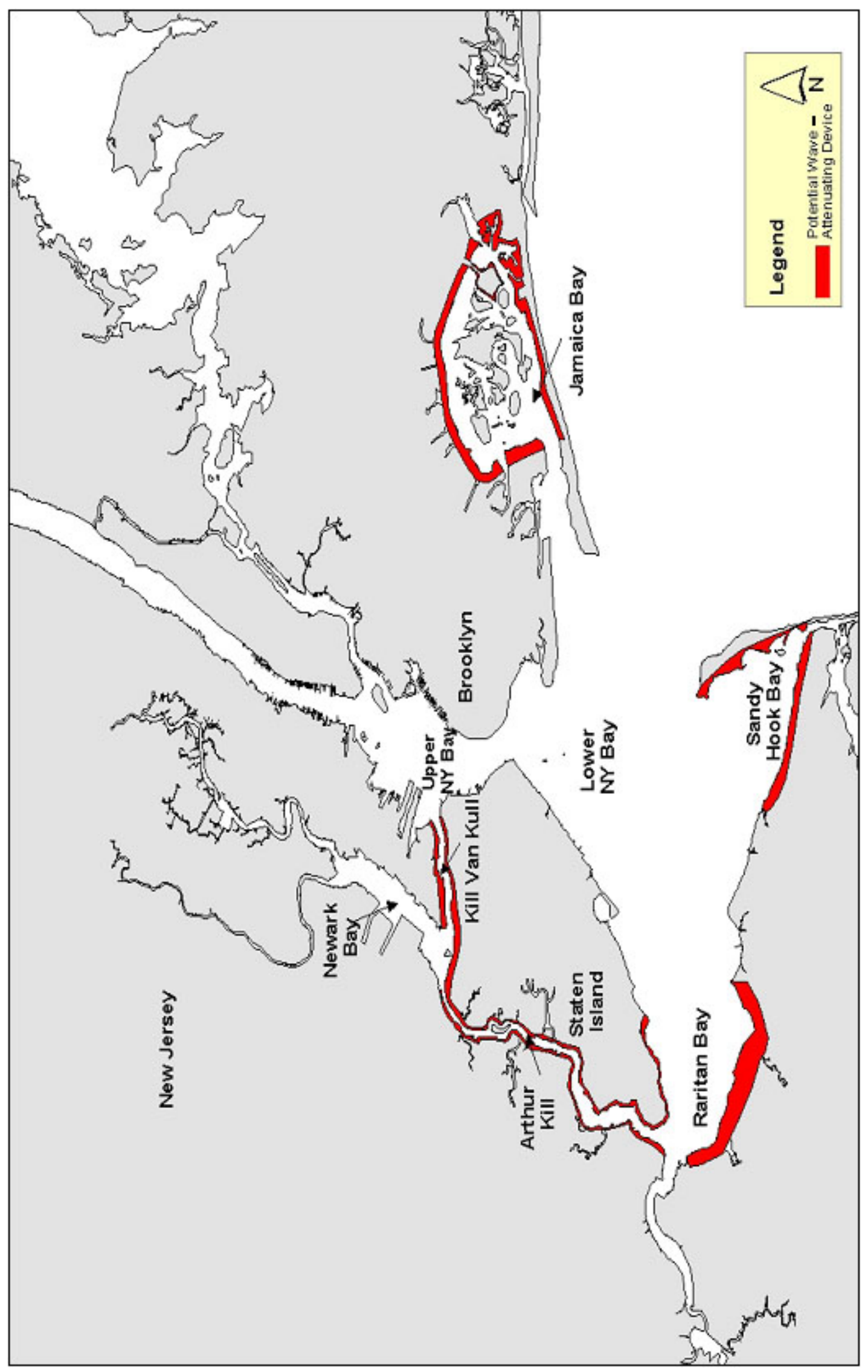

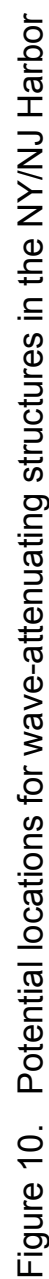


At the other location, which is yet to be final designed, it may be possible to utilize the full production of a dredge blast, either in layered construction or as a graded stone mass. Highlands will consume 53,000 cu yd of material sized up to $200-\mathrm{lb}$ rock. Keyport may be similar in size requirements but presumably about half the volume of Highlands.

\section{Groin, Jetty, and Revetment Construction}

\section{Groins and jetties}

Detailed beneficial use description. The development of groins and jetties with dredged material presents a viable option for utilizing bedrock beneficially. Groins are structures often composed of armor rock material of high durability that, when set perpendicular to the shoreline, are designed to trap littorally transported sediment. Jetties are also constructed of material of high durability set perpendicular to the shore; however, they typically extend outward beyond the littoral zone and are intended for the protection of inlets, harbors, and other marine waterways from sediment transport.

\begin{abstract}
December 19, 2001, Workshop Report on Shoreline Protection Structures: Shoreline protection structures, including groins, jetties, revetments, and seawalls, among others, provide USACE with the opportunity to protect valuable shoreline with physical structures that utilize the durable bedrock material being generated by this project. Important factors in determining use viability will include material hardness and durability, site-specific sediment transport dynamics, and potential for protecting land-based structures. In addition, the impact that each shoreline stabilization project may have on existing biological habitat should be evaluated. Sites where this may be applicable in the NY/NJ Harbor include the building of revetments in Bayonne and protection of Metropolitan Transportation Authority coastal infrastructure.
\end{abstract}

Implementation logistics. The volume of material required for the construction of a rock groin or jetty can range from 2,000 to 50,000 cu yd. Smaller materials are placed within a "core" and are confined with more durable larger rock on the outside, which acts as the "armor." Occasionally, groins are constructed using wire or mesh bags, referred to as gabions, to aggregate smaller material together into a larger structure. These variations have application in riverine and freshwater environments, but have shown limited success in saltwater environments. Blasted material may also be used in a systems approach to erosion protection. Large stone sizes culled from the blast mixture can be used to construct impervious groin and channel jetty structures. When constructed as rubble structures, both jetties and groins will typically be assembled with an impervious core, a sub armor layer, and an outer armor layer.

A hypothetical groin of dimensions $20 \mathrm{ft}$ high (toe to crest), crest width of $10 \mathrm{ft}$ with side slopes at $1.5 \mathrm{H}: 1 \mathrm{~V}$, and $200 \mathrm{ft}$ in length occupies a gross volume of approximately $6,000 \mathrm{cu}$ yd, and a net stone volume of $4,444 \mathrm{cu}$ yd assuming 25-percent voids. A typical barge of $200 \mathrm{ft}$ length, $40 \mathrm{ft}$ beam, and draft of $6 \mathrm{ft}$ would carry approximately $1,100 \mathrm{cu}$ yd of stone, so that construction of the groin would require approximately four barge loads of material if built using conventional design sections. However, to use the blasted rock from the harbor will 
require segregating the material into size categories, which adds handling costs to the product.

To avoid the cost of segregating the rock by size, using only the formula-sized pieces, a graded stone mass groin could be considered. Typically, graded mass sections require on the order of 50 percent more material than a layered design, so assume $6,500 \mathrm{cu}$ yd, or six barges of material per groin. Graded mass groins would generally be less permeable to sand infiltration than traditional design, so less leakage of the sand through the groin would occur. Side slopes of the graded mass groin would be expected to be flatter than the layered design; however, the visible, abovewater portion of the groin would be expected to be approximately the same size as for the layered design.

Depending on the specifics of the rock size distribution, the groin head might be expected to behave dynamically and move/deform in various wave conditions. If this is unacceptable, additional large armoring placed at the roundhead of the groin could be used to fix it in place. The trunk would likely be stable, especially if used in conjunction with a regularly maintained beach fill. Old groins can be rehabilitated by burying them inside a new graded stone groin section; however, the volume requirement is reduced, probably by at least 50 percent.

The logistics of graded mass rock for groin use would require adequate engineering and planning. If barges cannot approach the shore to bottom dump, then double handling of material might be required to empty the barges. It might be possible to dump in the surf zone at high tide, and then use land-based construction equipment to relocate the material on the back beach during low tide. Long-term storage of the material on the beach would likely be a public and aesthetic issue. Research work of the North Central Division of the USACE suggests that a coarse stone veneer placed on the beach would be the most effective stabilizing agent (Johnson 1987).

The rock might also be left in the surf zone to form artificial headlands and produce tombolos in lieu of a new groin, or as an alternate to reinforcing the existing groin. The material could also be placed as a submerged sill to hold back an artificially elevated beach, similar to the beaches that line the Chicago, IL, waterfront. The stability of the sill is defined similar to the stability of the submerged reef. The perched beach can also be filled with the smaller sized blast material creating a cobble beach more typical of a New England shoreline. Though less friendly to recreational users, the cobble beach provides positive shoreline protection and an alternative nearshore habitat environment. Stability of the cobble beach is similar to stability of the cobble blanket considered for a marsh edge.

Habitats and locations for project. Revetments groins and jetties are being considered for several locations along the Atlantic Ocean coast in New Jersey, such as Monmouth Beach and Spring Lake, and along both shores of Raritan Bay at Staten Island and Port Monmouth. The ocean front locations are primarily existing groin fields requiring modification for better sand retention and/or bypassing, while the Raritan Bay sites include shoreline enhancement. 
The Monmouth Lake location is a local "hot spot" of accelerated shoreline retreat. The remedial scheme originally called for a $100-\mathrm{ft}$ extension to groin number 44. However, completion of the beach nourishment in this area has mitigated the erosion problem, and no structural remedy is required. Spring Lake, about 5 miles south of Deal, NJ, has a similar erosional hot spot of approximately $2,000 \mathrm{ft}$ in length with an additional 3,000 ft of less critical erosion. The proposed scheme is to develop a series of detached breakwaters and/or tee-head groins and spurs between groins number 140 and 141. Because of the exposure, the required stone size will be larger than the material being produced from the bedrock blasting. The required volumes of the structures are also small with the remedial works only measuring a few hundred feet in total length. Given the stone size and the limited volume required, this location may require further processing and planning to achieve a desired result.

Within the Raritan Bay area, two other sites are located, Port Monmouth and a reach of the south shore of Staten Island. Port Monmouth requires the construction of terminal groins to limit sediment migration. Water depth and wave exposure call for cap stones in the 4- to 6-cu-yd range. The groins are yet to be designed. Material from the bedrock dredging could be used for sublayer and bedding/core material, but the size of the outer armor is incompatible with bedrock blast production.

Along the north shore, between Ft. Wadsworth and Oakwood Beach on Staten Island, a buried revetment, inside a dune, is planned. The revetment will require $2 \mathrm{cu}$ yd of armor stone in a layered design, which is larger than the current bedrock blast production capability. However, the size of the armor stone being called for is only marginally greater than what would be required for full potential use of the entire blast production, if the revetment were to be redesigned as a graded stone revetment. The present layered design calls for the use of $70,000 \mathrm{cu}$ yd of stone, half of which would be underlayer material that could presently utilize the smaller fractions of dredging. A redesigned revetment using a graded stone design to utilize the entire blast production might require $100,000 \mathrm{cu} y d$, and because it will be a buried revetment, would be a good candidate for this application.

\section{Revetments and seawalls}

Detailed beneficial use description. Revetments and seawalls are coastal protection devices that defend the shoreline from wave impact. Seawalls are generally mass structures usually shaped from sheetpile or concrete to protect the shoreline by deflecting wave energy. Revetments, on the other hand, are armored slopes intended to both absorb and resist the act of waves. They are built as a mound of rock of progressively varying size and dimension, placed against another surface to be protected.

Implementation logistics. Larger "armor" stone defines the bedrock that is most often used for both seawalls and revetments. However, rock of smaller size may be used in revetments for areas of less intense wave action. For revetments and seawalls, smaller material may be used as core stone to create a base for the placement of armor stone. As with the wave-attenuating systems, a revetment can 
be constructed in a conventional layered form for minimum volume use, or may be built in a graded stone matrix that occupies a larger volume but may be able to utilize somewhat smaller sized material.

Bedrock dredged by the USACE has been used to armor many coastal regions in the United States over the years. However, none of these projects have fallen under the beneficial use regulation. Best estimates would put average volume use between 2,000 and 5,000 cu yd per device. Totals could be much higher if a larger system were to be put in place. Available dredged rock could be employed in construction of shoreline stabilization activities in one of three ways: by using the material in its mixed size form in dumped construction, using the material in an unsorted form as a core material inside of an engineered structure, or sorting the material by size and selectively using the material as both core filer and as surface armor in traditional layered designs.

The use of the rock matrix in a "free dumped" construction mode is applicable when considering it in a dynamically stable rock slope $N_{s}=6$ to 20 , where $N_{s}$ is the stability number $N_{s}=H_{s} /\left[\left(d_{50}\right)\left(w_{r} / w_{w}-1\right)\right]$, where $w_{r}$ is the weight of rock and $w_{w}$ is the weight of water. For the larger values of $N_{s}(>14)$, the material behavior is more like a gravel beach (Ahrens and Heimbaugh 1989). Assuming a $d_{50}$ of $0.5 \mathrm{ft}$ and a weight of rock of $168 \mathrm{lb} / \mathrm{cu} \mathrm{ft}$ placed in salt water, the range of storm wave height applicability is 5 to $15 \mathrm{ft}$. The volume of material required to maintain protection $\left(A^{*}\right)$ is given by

$$
A^{*}=\frac{A^{\prime}}{H_{m 0} L_{0}}
$$

where

$$
\begin{aligned}
& A^{\prime}=\text { cross-sectional area above some designated water level } \\
& L_{0}=\text { deepwater wave length }
\end{aligned}
$$

From the Pearson Moskowitz spectrum, it can be shown that $L_{0} \cong 30 H_{m 0}$ (Sorensen 1978). Therefore, to resist the higher wave height scenarios, the volume required for stability is 90 times the volume needed for the lower wave height. In addition, the higher wave height likely is associated with a greater surge level, so that the reference waterline is higher. This would further increase the relative volume required.

The functional objective of a revetment is to provide protection to the shoreline with as small a footprint as possible. To resist the erosion, $A^{*}$ must be $>0.1$ (Ahrens and Heimbaugh 1989). Therefore, for a 5-ft wave, the required cross section must be $75 \mathrm{sq} \mathrm{ft} / \mathrm{ft}$ of shoreline. Assuming a dumped triangular wedge of material with a face sloped $2 \mathrm{H}: 1 \mathrm{~V}$, this represents a structure roughly $8.5 \mathrm{ft}$ high with a base of $17 \mathrm{ft}$. This is the largest practical footprint considered aesthetically acceptable. Therefore, the limit of applicability for use of the rock material taken directly from the blast is at locations that do not experience waves of $5 \mathrm{ft}$ in height. 
Rock taken from the blast could be used as fill volume for the core of coastal structures. A poorly sorted (wide gradation) mix is preferred with individual piece weights ranging from $W / 200$ to $W / 6000$ where $W$ is the weight of the required outer armor stone (USACE 1984). The finer gradation is preferred to minimize wave transmission through the structure; however, if construction is anticipated in an area frequented by moderate to severe wave conditions, a gradation with mean weights five to ten times larger is allowable to make the core more erosion resistant during construction (CIRIA 1991). Assuming a $d_{50}=0.5 \mathrm{ft}$ $\left(W_{50}=12 \mathrm{lb}\right)$ (USACE 2002), then the available material would be suitable for use in combination with primary armor applications up to 24 tons $\left(4000 * W_{50}\right)$. This is the practical upper bound for any quarried armor rock. Therefore, the dredged rock material is suitable as core material, which represents approximately 50 percent of the cost of the entire structure (CIRIA 1991).

Produced rock can also be processed by segregating the large material from the smaller material. Typically, the threshold of zero damage on a conventional revetment occurs when the wave is approximately two and a half times the stone dimension (Ward and Ahrens 1992). From the analysis presented in other sections, the typical large piece size is in the range of 4 to $5 \mathrm{ft}$, with applicability in wave heights up to 10 to $12 \mathrm{ft}$.

Habitats and locations for projects. Revetments and seawalls may have significant potential for beneficial use in the NY/NJ Harbor and surrounding waterways. There is interest from local government to obtain and use some of the dredged material for the purpose of rehabilitating revetments. The Town of Hempstead, a township in Nassau County, Long Island, is interested in obtaining 4,000 to $8,000 \mathrm{cu}$ yd of material to enhance a revetment in Point Lookout, a community on the easternmost end of Long Beach Island (Figure 11). With this and other beneficial use cases for revetments and seawalls there are economic and logistical factors to implementation. For these uses, the Town of Hempstead, which is seeking medium to larger sized material with significant durability and quality, has ample storage facilities to hold the material until its use is required. Currently, the town is purchasing material from Haverstraw, NY, and transporting it with their own trucks at a total cost of $\$ 10 / \mathrm{cu} \mathrm{yd}^{1}{ }^{1}$ The town is able to keep cost relatively low since the town owns the transportation vehicles.

However, there are constraints associated with using dredged bedrock in this region. The first major hurdle is how to transport the material to the location where it will be transferred to the town for storage. The barges that are currently in use with the KVK and AK projects are split-hull, deep-draft barges that cannot enter the shallow channels of Jones Inlet and Reynolds channel. As a result, the contractor would have to employ lesser draft barges, possibly not filled to capacity, to transport material to its destination. Also, the material may need to be sorted to the specification required. In this case, the material would be sorted either before or after storage. In both cases, the cost would rise significantly.

\footnotetext{
1 Personal communication, R. Masters, 2002, Town of Hempstead, Department of Conservation
} and Waterways, communication with Joel Banslaben. 


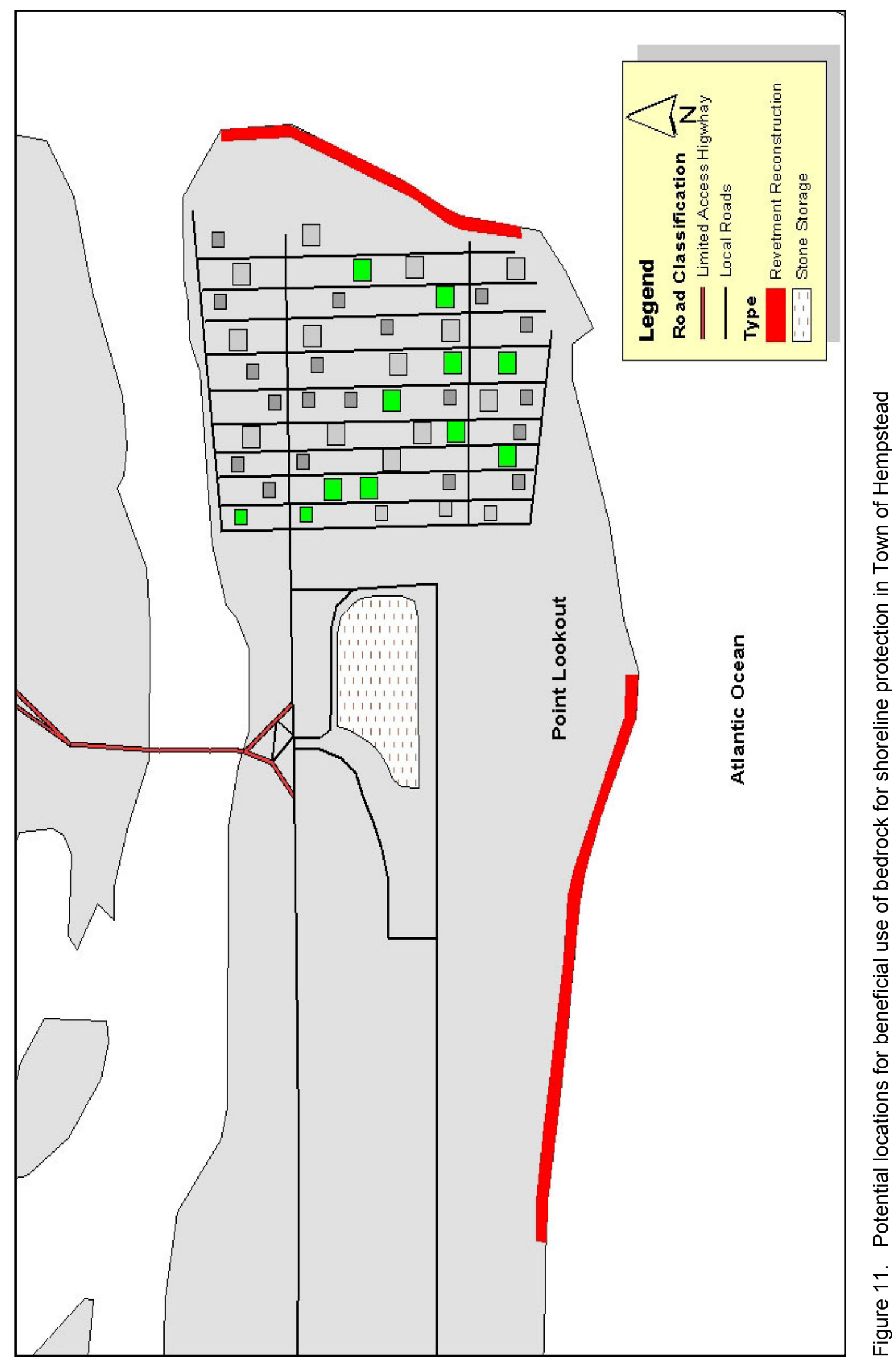


The cost of moving dredged rock from its current location to the offloading facilities, where the material can be transferred to land-based transportation and sorting facilities, will be significantly higher than dumping offshore. However, if the material can be used in its unsorted mode, or if limited sorting can be performed onsite, then some of this cost could be mitigated. The primary cost concern is the logistics of transport and offloading material at the project site, but water-based construction operation might further reduce that differential in cost. Logistically, the equipment used to move the material may need to be different if the depths of the channels used for moving material are of less depth than that used by split-hull barges. This may involve changing to a barge of less draft and tugboats of different capabilities. These equipment changes will be a factor in the increased costs of offloading the material and the human resources associated with the rehandling of the material. However, theses costs may be mitigated by the cost-sharing agencies that will no longer need to purchase and transport rock from inland quarries. Physically, the size of material needed for construction of seawalls and revetments is generally larger than material that will be produced by the current dredging and blasting of the KVK and AK. The material from this dredging project will most likely be used for core stone in revetments. The use of gabions or other bags may allow the material to be assimilated into larger structures.

\section{December 19, 2001, Workshop Report on Breakwaters: Offshore breakwaters have been suggested as an alternative form of shore protection for exposed, open coast shores. Research has shown that in these wave environs, 10 percent of the wave action causes 90 percent of the damage to the shore and property. The concept focuses on impeding larger waves with structures that are placed several yards below mean low water as to optimize wave reduction without creating a hazard to recreational activities. Potential implementation of this type of structure could be in areas with larger wave periods, including Coney Island, Long Beach, Sandy Hook, Monmouth, and Staten Island.}

\section{Breakwaters}

Detailed beneficial use description.

Breakwaters are structures that assist in the "breaking" of wave energy as waves approach the shore. This category of structures includes several types of devices including breakwater systems attached to the shore in a " $\mathrm{T}$ " formation and headland, single, system, and variations on the submerged breakwater concept. The majority of breakwater systems need material that is larger and more durable than most other types of shoreline protection. This size of material required does, however, depend on the

intensity of wave action in the desired area of breakwater development. For the different types of breakwaters there is the potential for different uses of the material. For attached breakwaters placed close to shore, the material needed would most closely resemble that of groins; that is, they could have an inner "core" of smaller material surrounded by larger "armor" stone for the exterior. Submerged breakwaters work by reducing longer period waves before they reach the shoreline. Also, submerged breakwaters would require significant engineering design before implementation due to sediment transport issues that would arise from placement.

Implementation logistics. Volumes for the beneficial use of bedrock material as breakwaters may range from 2,000 to $10,000 \mathrm{cu}$ yd depending on the 
extent of the systems. As a general guideline, the more complex the system of breakwater that is desired, the greater the amount of material that will be utilized for development. For submerged breakwaters, each unit could range from 3,000 to $5000 \mathrm{cu}$ yd for more complex systems.

Implementing breakwaters with dredged bedrock would require overcoming similar constraints to other shoreline protection devices. Logistically, the transfer of material from contractor to implementing agency would need further examination to determine the capabilities and added increased costs of rehandling. Using different barges than those currently in use would increase total project costs. The exception to this scenario would be if split hopper dredges could be positioned over the location of breakwater development and the rock released into position for placement. The material might still need to be sorted or capped with larger rock to prevent shoreward migration, adding additional costs. With attached breakwaters, the material would have to be either placed on a shallower draft barge or transferred to land for rehandling. Material may need to be sorted to create the proper engineering characteristics with smaller and mid-sized dredged rock.

Economically, the rehandling of the material would increase costs, as the amount of human resources necessary for project implementation increases. Additionally, costs would be expected to rise with the inclusion of sorting facilities and processes to separate larger armor stone from relatively smaller core material. Cost analysis to determine the feasibility of beneficial use projects should examine the entire project costs and compare with the dredging and breakwater total costs. Other constraints to implementing breakwaters in the NY/NJ Harbor would be hazards that may be created by constructing submerged devices to include navigation issues and public recreation hazards.

\section{Reduction of Loss for Salt Marsh, Mud Flat, and Shallow Habitats}

\section{Sediment feeder material}

Detailed beneficial use description. Sediment feeder material projects require material of lower hardness and durability than material needed for breakwaters or jetties. This includes shale and sandstone material that will be dredged in the NY/NJ Harbor. Utilizing these materials could have a dual function. Initially, the material would be expected to stabilize the shoreline. Over time the material would become weathered and dissolve into smaller elements of rock, acting as sand replenishment for eroding coasts. This type of beneficial use could be accomplished in both open coasts and embayments; however, it does not fall under a traditional beach nourishment project.

Implementation logistics. Preferable material for this type of beneficial use would be shale and sandstone expected to be produced by the dredging of the KVK and AK. Shale and sandstone are likely candidates for sediment feeder projects when compared to diabase and serpentinite because they will break down more rapidly into material that would be compatible with beach sediment based 
on geological durability and hardness factors of the material. Planning and engineering of projects that use shale and sandstone as feeder material would depend on the size and wave environment of the area to be nourished. Functional uses could range from $2,000 \mathrm{cu}$ yd in smaller projects to $10,000 \mathrm{cu}$ yd or more of material in both open coast and wetland/salt marsh applications.

Some materials being dredged from the channels have the potential of serving as a surrogate source of beach renourishment material. Along less publicly utilized stretches of the shoreline, for example Montauk Point, sandstone could be placed on the shoreline in lieu of current sand material. The sandstone would erode via wave action, gradually releasing the sediment into the littoral system, and in the interim, serving as more selective armoring for erosional hot spots. The primary issue to be addressed is how sandstone material will weather in different wave environs. The durability and hardness of the sandstone to be dredged need to be assessed to ascertain the time periods in which material would be expected to break down into functional beach sediment. Shale is not considered a candidate for beach use since it decomposes into very fine grain material, which would be lost to the surf. Another issue to be addressed is whether the material placement would be compatible with already existing beach uses. The breakdown of the sandstone would be similar to the creation of cobble beaches previously cited. This may or may not be viewed as acceptable aesthetically or recreationally. Once areas that are potentially compatible are determined, then the demand for such a use could be examined.

Economically, the cost of implementing the dual approach of "hard" shoreline stabilization and nourishment may be initially high, simply due to the relatively new nature of implementing a project of this nature. One important consideration is that other sources for sediment to be replaced on the beach are becoming limited. This approach provides a surrogate sediment source and at least temporary erosion control. Logistically, the barges used for the delivery would have to be of shallower draft because the material cannot be pumped as readily as sand is, unless this use was implemented in an area where deep draft channels border the degraded shore such as the KVK and AK. Permits may need to be obtained from respective state agencies to alter/enhance the habitat.

The banks of many navigation channels erode due to shallow draft vessels, minor wind waves, and potential geotechnical instability due to weak composition of soils in marshes and mud flats. Nearshore armoring of the shoreline with small-scale systems, compatible and conforming with the existing habitat, provides an opportunity for the biologic system to recover and restore its natural resistance to erosion by augmenting its sediment-restraining ability by either reducing erosive force or reinforcing the anchoring strength of the marsh plant root system. The protective system would ideally be constructed on or near the shoreline and would serve two functions: first, each structure would significantly cut down the amount of waves that reach the impacted shoreline, and, second, the structure would trap sand and silt material behind the device to build up and create marsh habitat.

Two strategies could be applied, permanent or interim protection. For permanent "engineered" protection, resilient material such as diabase could be used. Serpentinite would not be a candidate because of the chance for abrasion 
and release of a precursor to a carcinogenic substance in the surf zone. The other approach is to leverage the use of more easily friable sandstone and shale as slow release agents of renourishing sediment. By placing such material on the shore, immediate relief from erosive wave action occurs, and as the armor breaks down, the sediment produced becomes incorporated with the marsh sediment.

Eroding sandstone should be a reasonable direct replacement for lost sandy marsh edges, while the shale might only be suitable for silty backwater wetland edges. While not being a permanent fix, its lifespan might be projected to be several years, and would also serve to expand the marsh area. The erosion protection evoked with this strategy would have a finite life, similar to beach nourishment, and would need to be considered accordingly.

\section{Habitat restoration, enhancement, and creation}

Detailed beneficial use description. Habitat restoration and enhancement describe the use of material to improve ecosystems that are degraded or altered from their original state. This use would allow for habitat to be improved, increased, and/or rehabilitated to the benefit of the ecosystem for a variety of habitats including salt marsh, wetland, and benthic systems. To determine where this type use is applicable, the historical use of the habitat must be assessed and then compared to other degraded ecosystems. Adaptive management techniques that focus on clear, technically sound objectives, and flexibility to evolve by "learning by doing" will produce the most appreciable results (USACE 1999a). This would involve examining current species use and determining whether replacing or creating new habitat could provide a net gain in habitat. Use of rock for environmental restoration is generally preferable in urban environments, such as ports, where the material can be used to protect existing habitat. ${ }^{1}$

The beneficial use of dredged bedrock in the NY/NJ Harbor for habitat restoration and creation is a method for improving the value of the ecosystem while simultaneously utilizing rock material. Restoration and creation of valuable salt marsh, mud flat, and shallow water habitats of the area can be achieved by following the designs set forth in several habitat creation projects nationwide. One such project in Bodkin Island, MD, uses dredged material for the creation of habitat, with the use of rock material for the protection of developed lands (Maynord et al. 1992). Another, in the Port of Oakland, plans to restore 180 acres of shallow water habitat by creating islands within an intertidal mudflat embayment. ${ }^{1}$

\footnotetext{
1 Personal communication, R. Thom, 2002, Pacific Northwest National Laboratory (PNNL), Sequim, Washington, communication with Joel Banslaben.
} 
Combining the use of dredged material with dredged bedrock material has the potential to enhance the environment significantly. In this scenario, rock material serves the dual purpose of containing sediment and protecting it from external wave action. Stone, preferably of the armor variety, can be placed around the material used for habitat enhancement to protect the marsh from waves and wind action until it reaches a functional equilibrium (Maynord et al. 1992). Stone should be transported in partially loaded barges under high-tide conditions to decrease risk of the barge running ashore.

Implementation logistics. Dredged bedrock can be used effectively for habitat restoration, enhancement, and creation. For wetland and salt marsh enhancement, a variety of material types are compatible with stabilization and habitat creation schemes. For benthic environments such as borrow pits, all types of material could be used to restore habitat value. Volumes will depend on the size of the restoration project.

The marshes along the AK have lost edges resulting from tugboat wake erosion, submerged cut slope failure, or a combination of both. Geotechnical analyses of the planned slope cuts conducted during the 1997 Limited Reevaluation Report (LRR) indicated that the composite static factor of safety against slope failure generally ranged from 1.9 to 4 or more. Safety factors of 1.3 to 1.5 are considered adequate for long-term stability; however, perturbations to the slope, such as significant wake activity, can lower that safety factor. Many of the failure slip circles computed occurred on the upper portions of the slope, where soils were significantly softer and more prone to collapse. Therefore, localized failures are possible even though the gross slope is considered stable.

Four options are available for the use of the rock to stabilize the marsh edge. In the first option, if the marsh edge is geotechnically competent, low, segmental mounds of rock may be placed along the eroding marsh edge to counter the effects of wakes. Based on a calculation of boat wake size reaching the marsh edge, the required median stone diameter is $1.33 \mathrm{ft}$, and the height of the mound needs to reach roughly $2 \mathrm{ft}$ above the high-tide limit to ensure a wave transmission coefficient of 0.25 or less (van de Meer 1990). The mounds should be made discontinuous to allow free drainage. The mound shapes may also be curvilinear to create tidal pool areas, which form wave traps to better mitigate highly oblique boat wave approaches. The stone size may also be selected to produce desirable mound interstices to promote intertidal habitat.

An alternative scenario (the second option) would be as follows. The marsh edge may be eroding due to wake action and slope instability. In this case, construction of the rock reefs will only add an overburden weight to the slope face and promote or accelerate the slope failure. The construction of a marsh edge reef would require that the weak soil material on the channel slope be excavated to more competent material, and a larger rock section be built back up to the required height. If competent material does not appear within several feet of the marsh surface, this option is not viable because of the extensive amount of earthwork required. 
If the slope is only marginally stable, a relatively thin veneer of rock might be placed on the beach face to halt erosion. Given the soil strengths reported in the LRR, a nominal thickness of only $0.5 \mathrm{ft}$ overburden weight can be tolerated without slope failure. Based on Hudson's Equation for armor stability in waves, and assuming a breaking (boat) wave of $0.6 \mathrm{ft}$, and a beach slope angle of $10 \mathrm{H}: 1 \mathrm{~V}$, the required mean armor weight is $15 \mathrm{lb}$, or roughly 0.5 -ft-diam rock (USACE 1984). However, a two-stone-diameter thickness is recommended, which causes the overburden weight to exceed a stable load. Also, to develop this size range from the blasted rock will require sorting of the material prior to placement. As the beachface steepens, the required weight of stone increases linearly with the ratio of the slope change (5H:1V and $30 \mathrm{lb}$ ), making the overburden layer thicker and heavier yet. The revetment also has little residual erosion capacity past failure of the armor.

The third option is to cover the foreshore area with smaller produced stone $\left(D_{50}=5 \mathrm{~cm}\right.$ in diameter). The resultant gravel "beach" would be dynamically stable, deforming and conforming to the boat wake energy at various water levels. The construction template (actual sectional shape) of the initial gravel blanket placement has been found to be unimportant as the waves will adjust the profile to an equilibrium shape (Pilarczyk and den Boer 1983); only the total volume of material placed appears to matter.

Approximately $21 \mathrm{cu} \mathrm{m} \mathrm{(7} \mathrm{cu} \mathrm{yd/ft)} \mathrm{of} \mathrm{coarse} \mathrm{material} \mathrm{per} \mathrm{meter} \mathrm{of} \mathrm{shoreline}$ may be required to ensure long-term protection of a sandy shoreline. Ward and Ahrens (1992) refined this number for various water depths defined at the toe of beach slope. They assumed a wave period of $10 \mathrm{sec}$, and $H_{m o}=0.6 D_{s}$, where $D_{s}$ is the water depth at breaking. It can be shown from their data that the required volume is $V=13.9 D_{s}{ }^{1.7}$ (cubic meters/meter), which generally brackets the rule of thumb value offered by Johnson for most practical nearshore water depth ranges. Assuming a deep-water boat wake of $0.6 \mathrm{~m}$ height breaking in $1 \mathrm{~m}$ of water, the required volume of coarse material would be $13.9 \mathrm{cu} \mathrm{m} / \mathrm{m}(5.5 \mathrm{cu} \mathrm{yd} / \mathrm{ft})$.

For waves less than $1 \mathrm{~m}$ in height, the Dutch standard construction practice is to place a blanket of coarse material approximately $2.5 \mathrm{~m}$ thick along the shoreline. With an initial placement thickness of $2.5 \mathrm{~m}$, the blanket would then be $5.6 \mathrm{~m}$ wide. This will be problematic for slope stability overburden weight; however, the dynamic beach profile can more easily accommodate slope failures yet still function to absorb wave energy. If the soil is found to be stable, or can be recut to a stable slope of nominally $4 \mathrm{H}: 1 \mathrm{~V}$, this would be an option for using a larger percentage of the produced product.

For inland dikes, the fourth option, if the marsh edge is geotechnically unstable and unable to support the added weight of a protective reef structure or gravel veneer or beach, it is still possible to construct the structure further landward, beyond the limit of slope instability as determined in the LRR. The portion of the marsh to the channel side of the reef becomes sacrificial and is lost to a combination of wave action and slope instability over time. However, everything landward of the dike is permanently stabilized and protected. 
Other areas of coastal wetlands and beaches suffering erosion might benefit, at least on a temporary basis, with the placement of sandstone and shale along the edge to act as a sacrificial source of feeder material to the shoreline. In areas where aesthetics and/or public access are not critical, the erodible material could be allowed to disintegrate under wave attack, providing new fill material to the beach or wetland. The "feed" process would likely be slower than pure beach nourishment, giving the mitigative effort a longer life, but at the expense of being less controlled or uniform. Eroding sandstone should be a reasonable direct replacement for lost beach sand, while the shale might only be suitable for less exposed wetland edges. The erosion protection evoked with this strategy would have a finite life, similar to beach nourishment, and would need to be considered accordingly.

Habitats and locations for projects. At AK, geotechnical analysis of the slope stability for the planned channel excavation suggests that the areas most susceptible to slope failure occur near sta $34+00$ and sta $155+00$. In these areas,

December 19, 2001, Workshop Report on Commercial Sale of Dredged Bedrock: The use of dredged material as a source of construction material is a concept that has proven successful in the United States. The use of dredged bedrock is a relatively new concept that will require establishing proper logistics to go forward. The major factors in determining viability and usefulness will include the geological specifications of the material, material volumes, sorting facilities available, processing facilities available, and market factors. Each of these, plus the timing of deliverable material, will determine the feasibility of this option. It appears aggregate companies can use diabase as it is the hardest of all bedrock materials to be excavated from the NY/NJ Harbor. Sandstone and shale may be more difficult to sell, as they are softer materials and of less commercial value.

A significant determination of this includes the manner in which material is blasted and dredged as this has an impact on the size of the material produced. Improvements in blasting methods are currently being explored. Dredged bedrock as construction material can be construed as a beneficial use because it indirectly reduces the amount of material that needs to be mined from upland quarries. In addition, it cuts down on the land-based transportation needed for movement of material, especially if the material can be used locally (e.g., World Trade Center rebuilding). accidental overcutting of the dredge slope may trigger collapse that could be further exacerbated by channel deepening. The upper slopes are also of marginal strength to support any erosion control system. This suggests the inland dike option as the most viable. The obvious implication is that some loss of the marsh fringe edge will continue until the slope becomes flatter, and thus more stable. In areas where the slope failure plane meets the slope rather than the crest, it may be possible to invoke the other solutions, though the soil strengths, in general, do not support added overburden weights representing more than $0.5 \mathrm{ft}$ of rock material.

\section{Commercial Sale of Dredged Material}

\section{Detailed beneficial use description}

The commercial sale of dredged bedrock presents the USACE with an opportunity to combine beneficial use projects with economic production cycles. Dredged material of varying geological composition has been used to create construction materials including concrete, asphalts, and others. This process would entail collecting dredged bedrock from the NY/NJ Harbor and taking it to processing 
and sorting facilities. Materials must be sorted by size and geological composition and then processed to form viable construction materials. These materials may be sold by aggregate companies on the open market for infrastructure projects such as road and building construction, slope and streambank stabilization, and, potentially, some architectural applications.

Using dredged bedrock for commercial aggregate in the NY/NJ region may, in fact, have benefits that extend well beyond that of the direct market value of the material. First, reduced transportation costs will result from material, which has traditionally been transported from upstate quarries, being produced locally. Reduced transportation will also translate into reduced air pollution from landbased transportation in the region. Secondly, using bedrock material from the NY/NJ Harbor for aggregate material could significantly reduce the impacts that the commercial market would have on upland quarries in the same time span (Collins et al. 1994).

\section{Implementation logistics}

The only bedrock types suitable for creating industrial applications are those that are characterized as highly durable. One of the major issues with the use of dredged bedrock for industrial sale is the cost associated with the processing and sorting to make the material a viable commercial good. The volumes that can be accepted are based on the processing and sorting capacities of any given site. Diabase is a viable commercial aggregate. Serpentinite can be used if shown not to be an airborne hazard. Shale and sandstone have no commercial value, although sandstone may be used in some architectural settings if the application is nonstructural. If the sandstone had metamorphosed to quartzite, it can then be used in structural applications.

There is some potential market for the raw product, sorted by size. For this, the cost of the sorted product must be leveraged against a haul cost from a distant upland quarry. More likely, the majority of the product will be crushed to produce construction aggregate. The only limitation is an added $\$ 1 /$ ton-second handling charge, which is imposed on the bedrock material in comparison to the quarry sourced material. In most instances, that charge can be offset by lower hauling costs to a local construction site.

Processing and storing. Based on plant processing requirements for recycling concrete, a typical aggregate production operation will require a land area of roughly 5 acres just to accommodate the equipment and materials sorting area. This will need to be in immediate proximity of a dock for receiving the dredged bedrock. Storage of the raw product requires additional room. A goodsized portable aggregate plant, which includes both primary and secondary crushing machines and conveyor systems, will typically produce between 150 and $200 \mathrm{cu} \mathrm{yd} / \mathrm{hr}$, the secondary crusher capacity being the limiting factor. A 40- by 200 - by 6 - $\mathrm{ft}$ draft barge will deliver approximately $1,500 \mathrm{cu}$ yd of material. Therefore, the crusher operation must run an average of $10 \mathrm{hr} /$ day to keep pace with the delivery of a single daily barge. The present dredge operation generates 15 barges per day. Therefore, multiple crushing operations will be required, or storage capacity at the processing facility will be needed. 
Rock can be offloaded from barges using a backhoe for a charge of approximately $\$ 1 /$ ton (Ingraham 2002) and moved to a stockpile with heavy trucks. For traction and dump considerations, the steepest average slope achievable for the storage pile is approximately $20 \mathrm{deg}$. Therefore, the maximum volume stored per acre is roughly 9,000 cu yd. One-acre of land can accommodate delivery from approximately six barges. Entire commercial sale costs and specifications are noted in Table 7. The raw value of armor size rock material at a quarry is about $\$ 8 /$ cu yd. If everything is equal, assuming the same blast mix at a quarry or at the dredge, and assuming at least one more double handling, then the cost of transport and building of these structures should approach $\$ 7 / \mathrm{cu}$ yd. Depending on the structure, the final placement costs can range from $\$ 2$ to $\$ 8 / \mathrm{cu}$ yd, not including associated upland elements required with the structure.

\begin{tabular}{|c|c|c|}
\hline \multicolumn{3}{|c|}{$\begin{array}{l}\text { Table } 7 \\
\text { Commercial Costs and Sale Specifications }\end{array}$} \\
\hline Product & Raw Cost ${ }^{1}$ & Sorted Cost $^{2}$ \\
\hline A stone & \$8/ton & \$20/ton \\
\hline B stone & & $\$ 15 /$ ton \\
\hline Quarry run & & $\$ 7 /$ ton \\
\hline Aggregate & & $\$ 7 /$ ton \\
\hline \multicolumn{3}{|c|}{ Handling } \\
\hline Quarrying cost (inclusive) & & $\$ 10-12 /$ ton $^{1}$ \\
\hline Loader move & $\$ 0.50 /$ ton $^{1}$ & \\
\hline Second handling (offload) & $\$ 1 /$ ton $^{1}$ & \\
\hline Sorting & $\$ 3.50 /$ ton $^{1}$ & \\
\hline Crushing $^{3}$ & $\$ 5.00 /$ ton $^{1}$ & \\
\hline \multicolumn{3}{|c|}{ Hauling } \\
\hline Truck (20-ton load) & $\$ 70 /$ hour $^{1}$ & Hourly rate (distance/speed) \\
\hline Barge & & \$7/ton \\
\hline Shoreline placement & $\$ 6-12 /$ ton $^{1}$ & \\
\hline \begin{tabular}{|ll} 
& C Ingraham/S.E.H. \\
2 & M Stavola/Traprock. \\
3 & Portable crusher capacit
\end{tabular} & 0 tons/hr. & \\
\hline
\end{tabular}




\section{References}

Ahrens, J. P. (1988). "Reef breakwater response to wave attack," Berm Breakwaters, American Society of Civil Engineers.

Ahrens, J., and Heimbaugh, M.S. (1989). "Dynamic stability of dumped riprap," Coastal Zone '89, American Society of Civil Engineers, New York, NY.

Battelle Memorial Institute. (2002). "Beneficial use of dredged bedrock in the New York/New Jersey Harbor," 2 maps, Stony Brook, NY.

Battelle Seattle Research Center, Battelle Ocean Sciences. (1996). "Identifying, planning, and financing beneficial use projects using dredged material: Beneficial use manual," Prepared for U.S. Environmental Protection Agency, Oceans and Coastal Protection Division, Washington, DC.

Bhowmik, N. G. (1975). "Boat-generated waves in lakes," Technical Note, Journal of the Hydraulics Division, American Society of Civil Engineers, 1465-1468.

Bhowmik, N. G., Demissie, M., and Guo, C. -Y. (1982). "Waves generated by river traffic and wind on the Illinois and Mississippi Rivers," Report UILIWRC-82-167, Illinois State Water Survey, Champaign, IL.

Bhowmik, N. G., Soong, T. W., Reichelt, W. F., and Seddik, N. M. L. (1991). "Waves generated by recreational traffic on the Upper Mississippi River system," Research Report 117, Department of Energy and Natural Resources, Illinois State Water Survey, Champaign, IL.

Bohnsack, J. A. (1989). "Are high densities of fishes at artificial reefs the result of habitat limitation or behavioral preference?" Bulletin of Marine Science 44, 631-45.

Castro, K. M., Cobb, J. S., Wahle, R. A., and J. Catena. (2001). "Habitat addition and stock enhancement for American lobsters, Homarus americanus," Mar. Freshwater Res. 52, 1253-61.

Collins, K. J., Jensen, A. C., Lockwood, A. P. M., and Lockwood, S. J. (1994). "Coastal structures, waste materials, and fishery enhancement," Bulletin of Marine Science 55(2-3), 1240-1250. 
Construction Industry Research and Information Association. (1991). Manual on the use of rock in coastal and shoreline engineering, Balkema. Brookfield, VT.

Edgerton, L. T. (1991). The rising tide, global warming and world sea levels. Island Press, Washington, DC.

Figley, B., Preim, B., and Carlson, J. (2000). "A guide to fishing and diving New Jersey reefs," Division of Fish and Wildlife, New Jersey Department of Environmental Protection, Trenton, NJ.

Iocco, L. E., Wilber, P., Diaz, R. J., Clarke, D. G., and Will, R. J. (2000). "Benthic habitats of New York/New Jersey Harbor: 1995 survey of Jamaica, Upper, Newark, Bowery, and Flushing Bays," NOAA Coastal Services Center, Charleston, SC.

Johnson, C. N. (1987). "Rubble beaches versus rubble revetments," Coastal Sediments '87. American Society of Civil Engineers, New York, NY.

Ludwig, M. (2001). "Mitigation strategies that could be employed to lessen the immediate and long-term impacts of deepening the Port of New York and New Jersey," Milford Laboratory, National Marine Fisheries Service, Milford, CT.

Maynord, S. T., Landin, M. C., McCormick, J. W., Davis, J. E, Evans, R. A., and Hayes, D. F. (1992). "Design of habitat restoration using dredged material at Bodkin Island, Chesapeake Bay, Maryland," Technical Report WRP-RE3, U.S. Army Engineer Waterways Experiment Station, Vicksburg, MS..

National Marine Fisheries Service. (2001). "Draft national artificial reef plan revision," National Oceanographic and Atmospheric Administration, Gloucester, MN.

. (2002). "Guide to essential fish habitat designations in the northeastern United States," National Oceanographic and Atmospheric Administration, Gloucester, MN. http://www.nero.nmfs.gov/ro/doc/webintro.html.

National Oceanographic and Atmospheric Administration. (2002). "Lower Bay map atlas," Coastal Services Center, http://www.csc.noaa.gov/lcr/nyharbor/html/mapatlas/lbatlas.html.

NY/NJ Baykeeper. (2002). "New York - New Jersey Baykeeper," http://www.nynjbaykeeper.org/.

New Jersey Department of Environmental Protection. (1987). "Draft artificial reef management plan for New Jersey," Marine Fisheries Administration, Division of Fish, Game, and Wildlife, Trenton, NJ.

Republic, NJ. (2001a). "NJ reef news," Division of Fish and Wildlife, Port 
New Jersey Department of Environmental Protection. (2001b). "Survey of New Jersey's recreational wreck/artificial reef fisheries, 2000," Bureau of Marine Fisheries, Marine Fisheries Administration, Division of Fish and Wildlife, Trenton, NJ.

New York State Department of Environmental Conservation. (1993). "Final generic environmental impact statement and plan for the development of artificial reefs in New York's marine and coastal district," Division of Marine Affairs, Stony Brook, NY.

Northeast Fisheries Science Center. (2002). "Essential fish habitat source documents: Life history and habitat characteristics," National Marine Fisheries Service, National Oceanographic and Atmospheric Administration, Woods Hole, MA, http://www.nefsc.nmfs.gov/nefsc/habitat/efh/ - list.

PBS\&J. (2002). Engineering Analysis of Beneficial Use of Dredged Bedrock for "Beneficial use of dredged bedrock in the New York/New Jersey Harbor," performed by Jack Cox and Mark Perrillo, Chantilly, VA.

Permanent International Association of Navigation Congresses. (1987). "Guidelines for the design and construction of flexible revetments incorporating geotextiles for inland waterways," Working Group 4 of the Permanent Technical Committee, Brussels.

Pilarczyk, K. W., and den Boer, K. (1983). "Stability and profile development of coarse materials and their application in coastal engineering," Publication No. 293, Delft Hydraulics Laboratory, The Netherlands.

Scarratt, D. J. (1968). "An artificial reef for lobsters (Homarus americanus)," Journal of the Fisheries Research Board of Canada 25, 2683-90.

. (1973). "Lobster populations on a man-made rocky reef," International Council for the Exploration of the Sea, Shellfish and Benthos Committee C.M./K, Copenhagen, Denmark.

Sheehy, D. (1976). "Utilization of artificial shelters by the American lobster (Homarus americanus)," Journal of the Fisheries Research Board of Canada 33(7), 1615-22.

Sorensen, R. M. (1978). Basic coastal engineering. Wiley Interscience. . (1997). "Prediction of vessel-generated waves with reference to vessels common to the Upper Mississippi River System," ENV Report 4, U.S. Army Corps of Engineers, Rock Island, St. Louis, and St. Paul Districts.

Sorenson, R. M., and Weggel, J. R. (1984). "Development of ship wave design information." Proceedings of the $19^{\text {th }}$ Conference on Coastal Engineering. Houston, TX, 3-7 September 1984. Billy L. Edge, ed., American Society of Civil Engineers, New York, III, 3227-3243. 
Spanier, E. (1994). "What are the characteristics of a good artificial reef for lobsters?" Crustaceana 67, 173-86.

Turner, E. J., Zimmer-Faust, R. K., Palmer, M. A., Luckenback, M., and Pentcheff, N. D. (1994). "Settlement of oyster (Crassostrea virginica) larvae: Effects of water flow and a water-soluble clue," Limnology and Oceanography 39, 1579-93.

U.S. Army Corps of Engineers. (1984). Shore protection manual. $4^{\text {th }}$ ed., 2 vol., U.S. Army Engineer Waterways Experiment Station, U.S. Government Printing Office, Washington, DC.

. (1996). "Yonkers shoreline storm damage and erosion reduction reconnaissance study,” New York District, New York.

. (1997). "Final limited reevaluation report, Arthur Kill ChannelHowland Hook Marine Terminal," Technical Support Documents, New York District, New York.

. (1997). "Final limited reevaluation report, Kill Van Kull-Newark Bay Channels, Phase II Deepening Project," Technical Support Documents, New York District, New York.

(1998). "Existing biological data for the New York and New Jersey Harbor,” New York District, New York.

. (1999a). "Beneficial uses of dredged material for habitat creation, enhancement, and restoration in NY/NJ Harbor," New York District, New York.

. (1999b). "Draft dredged material management plan for the Port of New York and New Jersey, Implementation Report," New York District, New York.

. (2002). "Coastal engineering manual," Engineer Manual 1110-21100, Washington, DC (in 6 volumes), http://bigfoot.wes.army.mil/cem001.html

. (2002). "Estimates of current dredging schedules and volumes," New York District, New York.

U.S. Army Engineer Waterways Experiment Station. (1949). "Handbook for concrete and cement," Vicksburg, MS.

van der Meer, J. W. (1990). "Data on wave transmission due to overtopping," Report H 986, Delft Hydraulics, The Netherlands.

van der Meer, J. W., and Pilarczyk, K. W. (1987). "Dynamic stability of rock slopes and gravel beaches," Delft Hydraulics Communication No. 379, The Netherlands. 
Virginia Department of Environmental Quality. (2002). “The Virginia Oyster Heritage Program," Virginia Coastal Program, Richmond, VA http://www.deq.state.va.us/oysters.

Wahle, R. (1993). "Recruitment to American lobster populations along an estuarine gradient," Estuaries 16(4), 731-38.

Ward, D. L., and Ahrens, J. P. (1992). "Laboratory study of a dynamic revetment," Technical Report CERC-92-1, U.S. Army Engineer Waterways Experiment Station, Vicksburg, MS. 


\section{Appendix A Geological Specifications}

\section{Introduction}

Dredged bedrock material may potentially be used in numerous beneficial use alternatives in the NY/NJ Harbor. The measure by which all options will initially be weighed is that of geological specifications. Bedrock types, volumes, and characteristics affect the implementable options available to both federal and nonfederal sponsors of beneficial use projects. The first step of an overview decisionmaking process must be based upon geological information. This information can allow decisionmakers to determine precisely the potential options available for going forward with different types of bedrock material.

Rock types can be divided into four major subcategories of dredged material in the NY/NJ Harbor. Each of these subcategories can be applied in beneficial use

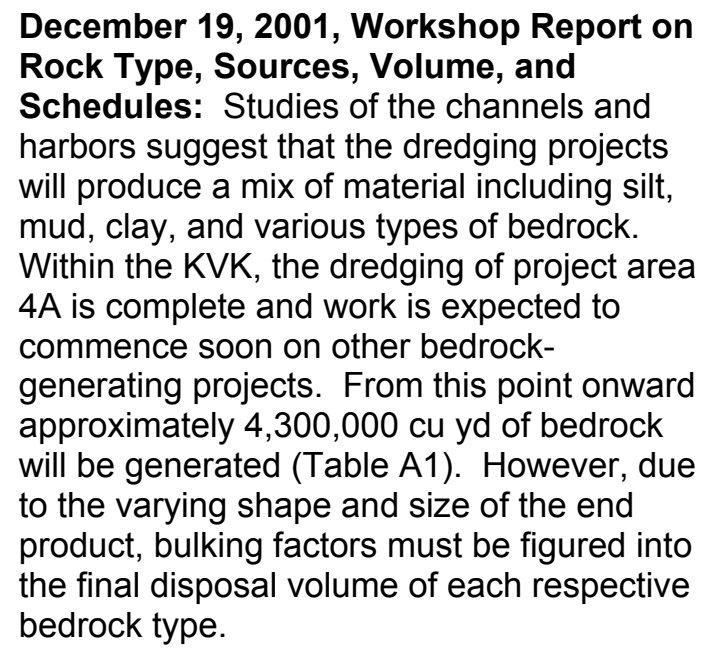
approximately $4,300,000 \mathrm{cu}$ yd of bedrock will be generated (Table A1). However, due to the varying shape and size of the end product, bulking factors must be figured into the final disposal volume of each respective bedrock type. options most suited to the identified type of material. For example, in the case of shale, most uses that protect the shoreline from high wave activity are discounted due to the inability of shale to withstand intense weathering action. As well, similar statements can be made of rock characteristics and volumes. Therefore, the geological characteristics of the dredged bedrock allow for options to be

\begin{tabular}{||l|l|l|l||}
\hline \multicolumn{4}{||l||}{$\begin{array}{l}\text { Table A1 } \\
\text { Bedrock Volumes and Bulking Factors for Projected Projects }\end{array}$} \\
\hline \hline Material Type & $\begin{array}{l}\text { Expected Volume } \\
\text { cu yd }\end{array}$ & Bulking Factor & $\begin{array}{l}\text { Total Placed Volume } \\
\text { cu yd }\end{array}$ \\
\hline \hline Diabase & $2,600,000$ & 2.0 & $5,200,000$ \\
\hline Shale & $2,500,000$ & 1.4 & $3,500,000$ \\
\hline Serpentinite & $1,400,000$ & 1.4 & $1,960,000$ \\
\hline Sandstone & $2,100,000$ & 1.8 & $3,780,000$ \\
\hline Total Bedrock Volume & $\mathbf{8 , 6 0 0 , 0 0 0}$ & & $\mathbf{1 4 , 4 4 0 , 0 0 0}$ \\
\hline \hline 1 & \multicolumn{3}{l||}{} \\
\hline
\end{tabular}




\section{December 19, 2001, Workshop Report on Geological Specifications: Two of the major fac-} tors in determining the suitability of bedrock material for beneficial use are geological composition and estimated volumes. The rock types in KVK and AK are classified as diabase, sandstone, serpentinite, and shale. Serpentinite may contain a precursor to asbestos and is not preferable for airborne use. Sandstone and shale are softer materials with potential use, depending on hardness and weathering capacity. Diabase is the most functional of the dredged materials for shoreline stabilization, being capable of maintaining structure when subjected to extreme natural forces. Geological characteristics that are important in determining the utility of bedrock in the marine environment include rock hardness, material density, temperature durability, and ability to withstand wave action.

Marine applications for the beneficial use of dredged bedrock material may include:

- Limited open coast use (berms/submerged breakwaters)

- Embayment (with rock sorting)

- Channel stabilization

- Marsh edge protection

There is the potential with softer sandstone for a combined use of shoreline stabilization and beach nourishment. In this scenario, the sandstone would temporarily act as a hardening structure, and then would undergo weathering under wave action, thus adding to beach material.

Several technical guidelines will assist in determining whether the bedrock material is suitable for beneficial use projects. Most importantly, the predominant average size of the bedrock material produced during the excavation will allow the USACE to determine the functionality of bedrock in different wave environments. The ratio of rock diameter to wave height can be used to calculate probable uses for the dredged bedrock in marine environments. If the average wave height is greater than 3.5 times that of the rock diameter, the rock is not viable for shoreline hardening structures. These numbers will determine if the material is viable for use in shore protection devices. rated on a scale based on preference for beneficial use. For each rock type then, rock characteristic and volumes will significantly assist or detract from the implementation of specific beneficial use options.

To assess the information regarding dredged bedrock material from the NY/NJ Harbor with respect to rock type, characteristics, and volumes, information can be obtained from different sources. The primary source of bedrock information is boring records developed by the USACE that reveal information at regular intervals of the types, breadth, and character of material that is expected to be dredged. These records are accessible through regional Corps districts' engineering and geological survey branches. In the case of the NY/NJ Harbor, the New York District of the USACE is in possession of annual studies that contain ample information regarding these characteristics.

Once the boring information has been assembled, the next step to understanding the geological specifications is a visual assessment of the material. This can be done by communicating with active contractors operating on the dredge area and inspecting material as it is transferred into the oceangoing barge. This can provide insight into the postblast and dredge characteristics of the material. In addition, chemical tests can be performed to better scope the durability and content of the material being dredged. Finally, volumes can be estimated using information on dredge schedules, areas, and depths to better estimate the specification of the rock. This information can then be used to determine the most applicable uses for the bedrock. 


\section{Identification of Rock Type, Sources, Volume, and Schedules}

Rock being excavated from the KVK channel falls into three classifications diabase and serpentinite (igneous), gneiss and schist (metamorphic), and shale and sandstone (sedimentary) as illustrated in Figure A1. The remaining material being excavated is silts and muds. Volumetrically, approximately 2.6 million cubic yards of diabase, 1.4 million cubic yards of serpentinite, 2.1 million cubic yards of sandstone, and 2.5 million cubic yards of shale are slated for removal. The metamorphic material occurs in incidental amounts. See Table A2.

\begin{tabular}{|c|c|c|c|c|}
\hline $\begin{array}{l}\text { Table A2 } \\
\text { Current Dr }\end{array}$ & dging Schedule & and Volume & JSACE 20 & \\
\hline Contract Area & Rock Volume, cu yd & Type & Bulk Factor & $\begin{array}{l}\text { Rock plus Bulk } \\
\text { cu yd }\end{array}$ \\
\hline & & Kill Van Kull 45’ & & \\
\hline $4 \mathrm{~B}$ & 201,722 & Diabase & 1.75 & 353,014 \\
\hline 5 & 766,593 & Diabase & 1.75 & $1,341,537$ \\
\hline 6 & 9,923 & Shale & 1.4 & 13,893 \\
\hline 7 & 7,796 & Shale & 1.4 & 10,915 \\
\hline 8 & 6,630 & Sandstone & 1.6 & 10,607 \\
\hline & & Harbor Study & & \\
\hline KVK A & 409,167 & Serpentinite & 1.4 & 572,834 \\
\hline KVK B & 409,167 & Serpentinite & 1.4 & 572,834 \\
\hline KVK C & 568,954 & Serpentinite & 1.4 & 796,536 \\
\hline KVK F & 471,395 & Diabase & 1.75 & 824,941 \\
\hline KVK G & 471,395 & Diabase & 1.75 & 824,941 \\
\hline KVK H & 477,724 & Diabase & 1.75 & 836,017 \\
\hline KVK I & 385,324 & Sandstone & 1.6 & 616,518 \\
\hline NB A & 738,151 & Sandstone & 1.6 & $1,181,042$ \\
\hline NB B & 193,265 & Sandstone & 1.6 & 309,224 \\
\hline NB C & 10,134 & Shale & 1.4 & 14,188 \\
\hline NB E & 72,064 & Shale & 1.4 & 100,890 \\
\hline NB F & 236,008 & Diabase & 1.75 & 413,014 \\
\hline AKA & 546,182 & Shale & 1.4 & 764,655 \\
\hline AK B & 546,182 & Shale & 1.4 & 764,655 \\
\hline$A K C$ & 649,381 & Shale & 1.4 & 909,133 \\
\hline$A K D$ & 649,381 & Shale & 1.4 & 909,133 \\
\hline AK E & 827,735 & Sandstone & 1.6 & $1,324,376$ \\
\hline \begin{tabular}{|l} 
Hard Rock \\
Blasted \\
\end{tabular} & $1.50-2.00$ & Diabase (1.75) & KVK CA 4,5,6 & and 8 \\
\hline $\begin{array}{l}\text { Medium Rock } \\
\text { Blasted }\end{array}$ & $1.40-1.80$ & Sandstone (1.60) & KVK CA5, AK & $61 \mathrm{~A}$ \\
\hline Soft Rock Blaste & $1.25-1.40$ & \begin{tabular}{|l} 
Serpentinite and \\
Shale(1.40)
\end{tabular} & KVK CA1, 2,7 & $8+\mathrm{AK} 2,3,4$ \\
\hline
\end{tabular}

Currently the rock is drilled and blasted for maximum efficiency in excavation, though some of the softer stones such as the shale can be broken or ripped mechanically. The excavation technique is clamshell and backhoe bucket. Estimates of rock size range from coarse gravels of typical inch dimension up to boulder size of 4 - to 5 - $\mathrm{ft}$ characteristic dimension. The majority of stone pieces fall in the size range of 1 to $3 \mathrm{ft}$, with at least 70 percent of all material (estimated visually) less than $1 \mathrm{ft}$ in dimension. For planning purposes, a $D_{50}$ equal to $0.5 \mathrm{ft}$ is assumed. Observationally, the igneous-based rocks taken from the harbor 
bottom appear to fracture into more cubical shapes while the sedimentary rocks appear to produce slabby shaped pieces.

Basic rock properties are summarized in Table A3. For rock intended to be used as erosion armor, higher tensile and shear strengths produce greater durability and resistance to weathering. Generally, igneous and metamorphic material serves well as armor stone, while sedimentary material does not. The exceptions to this are quartzite, a form of sandstone, and some formations of limestone, both sedimentary materials, which function well as armor material, and marine basalts (igneous), which perform very poorly due to rapid weathering. Of the material being removed from the harbor bottom, only the diabase is viable as candidate armor rock material. Use of the serpentinite as a parent material for asbestos should be avoided in any application that involves potential abrasion, especially if exposed to the air to avoid the possible release of the contaminant to the free environment. Table A4 indicates the relative suitability of various rock materials for use in marine structures applications, while Table A5 summarizes the additional requirements for materials to be used, unprocessed, as erosion-armoring material.

\begin{tabular}{|c|c|c|c|c|}
\hline \multicolumn{5}{|c|}{$\begin{array}{l}\text { Table A3 } \\
\text { Physical Characteristics of Rock Material (PBS\&J 2002) }\end{array}$} \\
\hline $\begin{array}{l}\text { Typical Rock } \\
\text { Type }\end{array}$ & $\begin{array}{l}\text { Compressive } \\
\text { Strength, MPa }\end{array}$ & $\begin{array}{l}\text { Tensile Strength } \\
\mathrm{MPa}\end{array}$ & $\begin{array}{l}\text { Shear Strength } \\
\mathrm{MPa}\end{array}$ & $\begin{array}{l}\text { Bulk Density } \\
\mathrm{mg} / \mathrm{m}^{3}\end{array}$ \\
\hline Granite & 100-250 & $7-25$ & $14-50$ & $2.6-2.9$ \\
\hline Diorite & $150-300$ & $15-30$ & $\mathrm{~N} / \mathrm{A}$ & $\mathrm{N} / \mathrm{A}$ \\
\hline Diabase & $100-350$ & $15-35$ & $25-60$ & $2.7-3.05$ \\
\hline Gabbro & $150-300$ & $15-30$ & $\mathrm{~N} / \mathrm{A}$ & $2.8-3.1$ \\
\hline Basalt & $100-300$ & $10-30$ & $20-60$ & $2.8-2.9$ \\
\hline Gneiss & $50-200$ & $5-20$ & $\mathrm{~N} / \mathrm{A}$ & $2.8-3.0$ \\
\hline Marble & $100-250$ & $7-20$ & $\mathrm{~N} / \mathrm{A}$ & $2.6-2.7$ \\
\hline Slate & $100-200$ & $7-20$ & $15-30$ & $2.6-2.7$ \\
\hline Quartzite & $150-300$ & $10-30$ & $20-60$ & $2.6-2.7$ \\
\hline Sandstone & $20-170$ & $4-25$ & $8-40$ & $2.0-2.6$ \\
\hline Shale & $5-100$ & $2-10$ & 3-30 & $2.0-2.4$ \\
\hline Limestone & $30-250$ & $5-25$ & $10-50$ & $2.2-2.6$ \\
\hline Dolomite & $30-250$ & $15-25$ & $\mathrm{~N} / \mathrm{A}$ & $2.5-2.6$ \\
\hline Steel & $900-1500$ & $\mathrm{~N} / \mathrm{A}$ & N/A & $\mathrm{N} / \mathrm{A}$ \\
\hline
\end{tabular}




\begin{tabular}{|c|c|c|c|c|}
\hline \multicolumn{5}{|c|}{$\begin{array}{l}\text { Table A4 } \\
\text { Evaluation of Rock Suitability: Generalized Evaluation of the Use } \\
\text { of Fresh Rock in Marine Structures (PBS\&J 2002) }\end{array}$} \\
\hline Rock Group & $\begin{array}{l}\text { Armorl } \\
\text { Facings } \\
\end{array}$ & $\begin{array}{l}\text { Underlayers/ } \\
\text { Filters } \\
\end{array}$ & $\begin{array}{l}\text { Corel } \\
\text { Fill } \\
\end{array}$ & Comments \\
\hline \multicolumn{5}{|c|}{$\begin{array}{c}\text { Igneous } \\
\end{array}$} \\
\hline 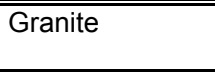 & $\overline{P \mathrm{PU}^{1}}$ & $\mathrm{PU}$ & $\overline{P U U}$ & $\begin{array}{l}\text { Good equant shapes; beware of } \\
\text { weathered rock }\end{array}$ \\
\hline Diorite & PU & PU & PU & $\begin{array}{l}\text { Good equant shapes; beware of } \\
\text { weathered rock }\end{array}$ \\
\hline Gabbro & PU & $\mathrm{PU}$ & $\mathrm{PU}$ & $\begin{array}{l}\text { Good equant shapes; beware of } \\
\text { weathered rock }\end{array}$ \\
\hline Fresh Rhyolite & & PU & PU & $\begin{array}{l}\text { Blocks typically angular, equant but } \\
\text { small }\end{array}$ \\
\hline Andesite & PU & PU & $\mathrm{PU}$ & $\begin{array}{l}\text { Block sizes sometimes small; beware } \\
\text { of weathered rock }\end{array}$ \\
\hline Basalt & PU & PU & PU & $\begin{array}{l}\text { Equant blocks sometimes small; } \\
\text { beware of weathered to vesicular }{ }^{2} \\
\text { rock }\end{array}$ \\
\hline Serpentine & PU & PU & $\mathrm{PU}$ & $\begin{array}{l}\text { Often the blocks are angular and } \\
\text { small }\end{array}$ \\
\hline \multicolumn{5}{|c|}{ Sedimentary } \\
\hline Pure Quartzite & $\overline{P U}$ & $\overline{P U}$ & 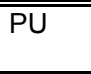 & $\begin{array}{l}\text { Sometimes poor tabular shapes. } \\
\text { Abrasion resistance sometimes poor }\end{array}$ \\
\hline Sandstone & PU & PU & PU & $\begin{array}{l}\text { Sometimes tabular and soft. } \\
\text { Abrasion resistance sometimes poor }\end{array}$ \\
\hline Siltstone & & & $\mathrm{PU}$ & Usually tabular and of small size \\
\hline Shale & & & $\mathrm{PU}$ & Small tabular fragments, soft ${ }^{3}$ \\
\hline Pure Limestone & PU & PU & PU & Sometimes tabular, sometimes soft ${ }^{3}$ \\
\hline Chalks & & & $\mathrm{PU}$ & Soft, easily eroded \\
\hline \multicolumn{5}{|c|}{ Metamorphic } \\
\hline Slate & & & $\begin{array}{l}\mathrm{PU} \\
\end{array}$ & $\begin{array}{l}\text { Tabular shape, hard, has been used } \\
\text { as armor }\end{array}$ \\
\hline Phyllite & & & $\mathrm{PU}$ & Elongate shapes, often soft \\
\hline Schist & $\mathrm{PU}$ & $\mathrm{PU}$ & $\mathrm{PU}$ & $\begin{array}{l}\text { Elongate and tabular shaped } \\
\text { common }\end{array}$ \\
\hline Gneiss & PU & PU & PU & $\begin{array}{l}\text { Good equant shapes, hard; beware of } \\
\text { weathered rock and micaceous } \\
\text { planes }\end{array}$ \\
\hline Marble & PU & PU & PU & Usually good equant shapes \\
\hline \multicolumn{5}{|c|}{$\begin{array}{ll} & \text { PU = Potentially of use. } \\
2 & \text { Of which pumice is an extreme example. } \\
3 & \text { When it is necessary to use these materials, consideration should be given to options using } \\
\text { geotextiles. }\end{array}$} \\
\hline
\end{tabular}




\begin{tabular}{|c|c|c|}
\hline \multicolumn{3}{|c|}{$\begin{array}{l}\text { Table A5 } \\
\text { Laboratory Tests and Specifications for Acceptable Armor } \\
\text { Product }^{1}\end{array}$} \\
\hline Test & Required Value & Test Method \\
\hline Specific gravity & $>2.65$ & ASTM C127 \\
\hline Water adsorption & $<1.0 \%$ & ASTM C127 \\
\hline Sodium sulfate soundness & $\begin{array}{l}<5 \% \text { loss } \\
\text { (after } 5 \text { cycles) }\end{array}$ & ASTM C88 \\
\hline Freeze thaw & $\begin{array}{l}<0.5 \% \text { loss } \\
\text { (after } 25 \text { cycles) }\end{array}$ & ASTM C666 \\
\hline $\begin{array}{l}\text { Expansive breakdown } \\
\text { (Ethylene glycol) }\end{array}$ & $\begin{array}{l}<5 \% \text { loss } \\
\text { (after } 15 \text { days) }\end{array}$ & CRD C148 ${ }^{2}$ \\
\hline Methylene blue adsorption & $<0.7 \%$ & -- \\
\hline $\begin{array}{l}\text { Unconfined compressive } \\
\text { strength }\end{array}$ & $>15,000 \mathrm{psi}$ & ASTM D2938 \\
\hline L.A. abrasion & $\begin{array}{l}<30 \% \text { loss } \\
\text { (after } 1,000 \mathrm{rev})\end{array}$ & ASTM C535 \\
\hline Block integrity drop test ${ }^{2}$ & $<5 \%$ & -- \\
\hline \multicolumn{3}{|c|}{$\begin{array}{l}\text { U.S. Army Engineer Waterways Experiment Station (1949). } \\
\text { Armor capstone material only. } \\
\text { Note: Typical armor specifications: } \\
\text { (1) The product will be dense, hard, sound, angular, close-grained durable rock, free from } \\
\text { overburden material that will not slake or deteriorate on exposure to the action of water or } \\
\text { atmosphere. } \\
\text { (2) Rock will be free of cracks, joints, faults, flaws, seams or mineral infillings, or other defects that } \\
\text { would tend to increase its deterioration from the weathering process or result in breakage during } \\
\text { normal handling, placing, or service. } \\
\text { (3) Products will be quarried during the period between March } 1 \text { and December } 1 \text {. Products will } \\
\text { be cured for a minimum of } 48 \mathrm{hr} \text { prior to classification and shipment. } \\
\text { (4) Products may be quarried between November } 1 \text { and April } 1 \text {, provided the products will be } \\
\text { cured for a minimum of } 168 \mathrm{hr} \text { after blasting during which time the average atmospheric } \\
\text { temperature does not drop below } 40{ }^{\circ} \mathrm{F} \text { prior to classification and shipment. The requirement may } \\
\text { be wavered for igneous and metamorphic rock, or other rock whose history shows conclusively } \\
\text { that the stone is durable irrespective of the time of year that it is quarried. } \\
\text { (5) Armor capstone products will be produced only from areas free of marine basalt flows, reefs, } \\
\text { shale, or chart. } \\
\text { (6) The material will be well graded and possess grading curves that do not exhibit abrupt } \\
\text { changes in slope denoting skip grading, scalping of certain sizes, or any other irregularities. } \\
\text { (7) The stone will be generally cubical or semirectangular in shape. The least dimension of any } \\
\text { piece of this stone will not be less than one-third of its greatest dimension. }\end{array}$} \\
\hline
\end{tabular}




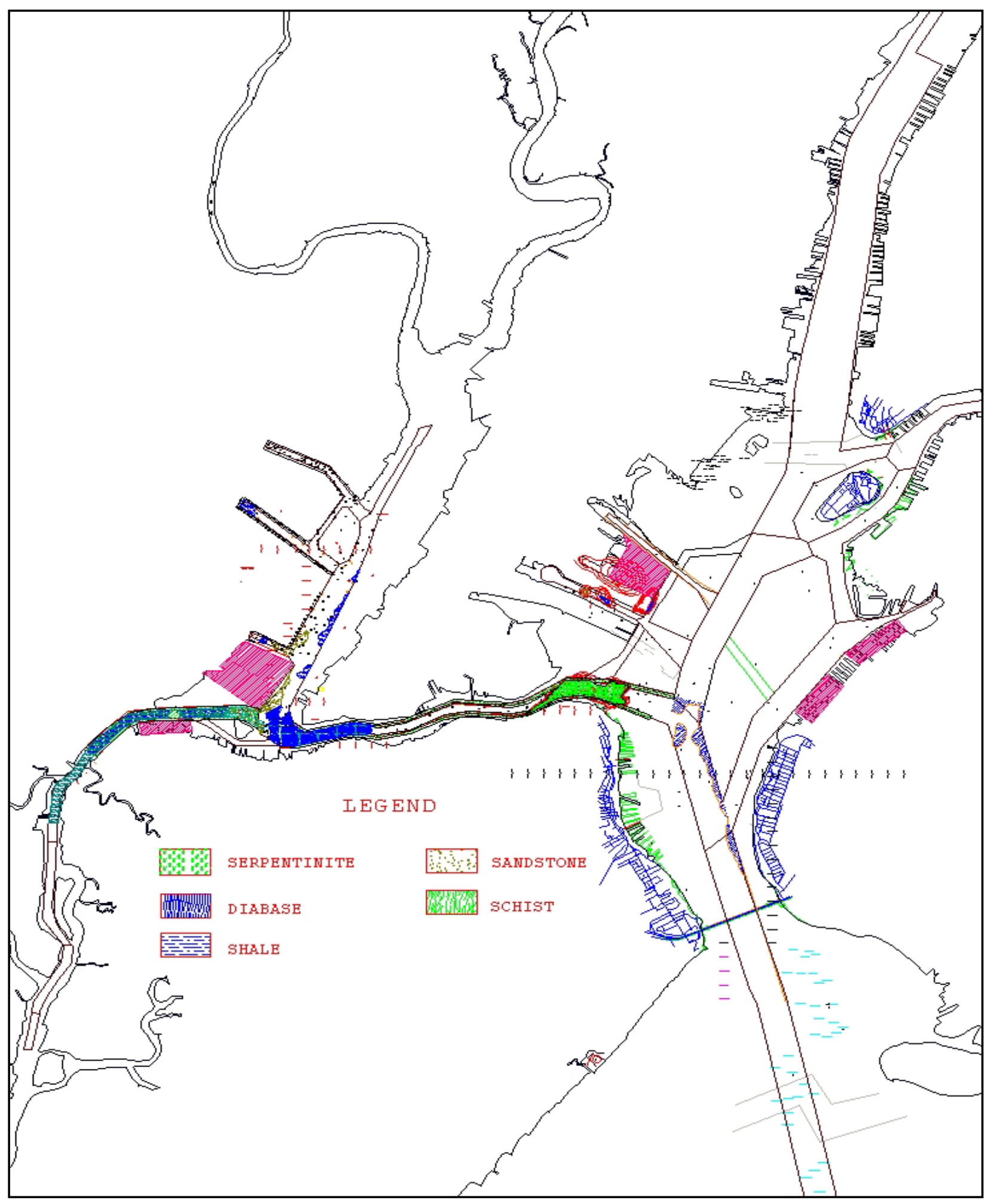

Figure A1. Map of geological dredge areas and types (USACE 2002) 


\section{Appendix B Overview of Beneficial Use of Dredged Bedrock: Issue Analysis}

\section{Introduction}

There are several issues to beneficially using dredged bedrock in the NY/NJ Harbor that may impact the overall benefit of the alternative. These issues include engineering, environmental, economic, institutional, and regulatory constraints. In this appendix the general implementation issues to the beneficial use of dredged bedrock will be examined. Recommendations have been generated to illustrate the manner to best integrate a beneficial use approach. The analysis of beneficial use options against major issues reveals some basic indications of potential success as indicated in Table B1. Artificial reefs have only minor limitations as the engineering of reefs is relatively simple, the economic costs are comparatively low, and currently institutional factors are minimal. Environmental constraints are moderate due to the lack of knowledge regarding concentration of fish populations and habitat dynamics. Other alternatives, such as sediment feeder material, could have significant limits due to engineering required to regulate the transport of material placed in the intertidal zone.

\section{Environmental Issues}

To use dredged bedrock in an environmentally beneficial manner, project improvements to habitat must outweigh the degradation or alteration to surrounding ecosystems. The environmental issues discussed below may limit the feasibility of several beneficial use alternatives as illustrated in Table B2. Mitigating with appropriate measures can provide an opportunity to increase benefit. 


\begin{tabular}{|c|c|c|c|c|c|}
\hline $\begin{array}{l}\text { Table B1 } \\
\text { Beneficia }\end{array}$ & se of $\mathrm{Dr}$ & ed Bedro & Issues & erview & \\
\hline & & & or Issue Gro & & \\
\hline $\begin{array}{l}\text { Beneficial } \\
\text { Use Option }\end{array}$ & Engineering & Environmental & Economic & $\begin{array}{l}\text { Institutional } \\
\text { (Federal/Non- } \\
\text { Federal) } \\
\end{array}$ & Regulatory \\
\hline $\begin{array}{l}\text { Artificial } \\
\text { reefs }\end{array}$ & N & PP & $\mathrm{N}$ & $\mathrm{N}$ & $P$ \\
\hline Oyster reefs & $\mathrm{N}$ & $\mathrm{N}$ & $P$ & $P$ & $P$ \\
\hline Lobster reefs & $\mathrm{N}$ & $\mathrm{N}$ & $\mathrm{P}$ & $\mathrm{P}$ & $\mathrm{N}$ \\
\hline Inshore reefs & $P$ & $\mathrm{~N}$ & $P$ & $C$ & $P$ \\
\hline $\begin{array}{l}\text { Sediment } \\
\text { feeder } \\
\text { material }\end{array}$ & C & $P$ & $P$ & $\mathrm{P}$ & $P$ \\
\hline $\begin{array}{l}\text { Groins \& } \\
\text { jetties }\end{array}$ & $P$ & $P$ & C & C & $P$ \\
\hline Revetments & $\mathrm{N}$ & $\mathrm{N}$ & $\mathrm{P}$ & $\mathrm{P}$ & $\mathrm{N}$ \\
\hline Seawalls & $P$ & $P$ & $P$ & $C$ & $P$ \\
\hline Breakwaters & $\mathrm{P}$ & $\mathrm{P}$ & $\mathrm{N}$ & $C$ & $\mathrm{P}$ \\
\hline $\begin{array}{l}\text { Wave- } \\
\text { attenuating } \\
\text { devices }\end{array}$ & C & $\mathrm{N}$ & $P$ & $P$ & $P$ \\
\hline $\begin{array}{l}\text { Aggregate } \\
\text { production }\end{array}$ & $P$ & $\mathrm{~N}$ & $\mathrm{~N}$ & C & $P$ \\
\hline $\begin{array}{l}\text { Notes: Benefi } \\
\text { presented cun } \\
\text { each issue ma } \\
\text { Chapter } 3 \text { and } \\
1 \mathrm{~N}=\text { No sign } \\
\text { Implementatio }\end{array}$ & $\begin{array}{l}\text { lase issue an } \\
\text { latively in the } \\
\text { have on the in } \\
\text { ppendix C. } \\
\text { icant implemen } \\
\text { constraints. }\end{array}$ & $\begin{array}{l}\text { yses are based or } \\
\text { ernatives section. } \\
\text { lementation of a } \\
\text { ation issues; } \mathrm{P}=\mathrm{P}\end{array}$ & $\begin{array}{l}\text { a detailed exa } \\
\text { These rating } \\
\text { ven project. } \\
\text { otential implen }\end{array}$ & $\begin{array}{l}\text { nation of the infor } \\
\text { relative indices } \\
\text { more information } \\
\text { tation issues; C }\end{array}$ & $\begin{array}{l}\text { mation } \\
\text { f the impacts } \\
\text { see }\end{array}$ \\
\hline
\end{tabular}

\begin{tabular}{|l|l|l|l|l||}
\hline \multicolumn{5}{||}{$\begin{array}{l}\text { Table B2 } \\
\text { Beneficial Use of Dredged Bedrock: Environmental Issues }\end{array}$} \\
\hline \hline \multirow{3}{*}{ Beneficial Use Option } & $\begin{array}{l}\text { Ecosystem } \\
\text { Impacts }\end{array}$ & $\begin{array}{l}\text { Reef } \\
\text { Capacity }\end{array}$ & $\begin{array}{l}\text { Navigational } \\
\text { Hazards }\end{array}$ & $\begin{array}{l}\text { Infrastructure } \\
\text { Hazards }\end{array}$ \\
\hline \hline Artificial reefs & $\mathrm{N}$ & $\mathrm{P}$ & $\mathrm{P}$ & $\mathrm{N}$ \\
\hline Oyster reefs & $\mathrm{N}$ & $\mathrm{N}$ & $\mathrm{C}$ & $\mathrm{P}$ \\
\hline Lobster reefs & $\mathrm{N}$ & $\mathrm{N}$ & $\mathrm{C}$ & $\mathrm{N}$ \\
\hline Inshore reefs & $\mathrm{N}$ & $\mathrm{N}$ & $\mathrm{C}$ & $\mathrm{P}$ \\
\hline Sediment feeder material & $\mathrm{P}$ & - & - & $\mathrm{C}$ \\
\hline Groins \& jetties & $\mathrm{P}$ & - & $\mathrm{C}$ & $\mathrm{P}$ \\
\hline Revetments & $\mathrm{P}$ & - & $\mathrm{N}$ & $\mathrm{P}$ \\
\hline Seawalls & $\mathrm{C}$ & - & $\mathrm{N}$ & $\mathrm{P}$ \\
\hline Breakwaters & $\mathrm{P}$ & - & $\mathrm{C}$ & $\mathrm{P}$ \\
\hline Wave-attenuating devices & $\mathrm{C}$ & - & $\mathrm{C}$ & $\mathrm{P}$ \\
\hline Aggregate production & $\mathrm{P}$ & - & $\mathrm{N}$ & $\mathrm{N}$ \\
\hline \hline $\begin{array}{l}\mathrm{N}=\text { No Significant implementation issues; P } \\
\text { Implementation constraints. }\end{array}$ & \multicolumn{4}{|l||}{ Potential implementation issues; C = } \\
\hline \hline
\end{tabular}

\section{Ecosystems impacts}

Impact assessment. Beneficial uses may involve the creation or restoration of habitat and shore stabilization. The impacts on species, especially if endangered, must be evaluated. Migratory species and juveniles may need to be 
examined to determine which life cycle will be affected. Specific species may be intentionally targeted due to recreational preference or commercial consideration. Evaluations may be necessary as to the overall impact on the ecosystem that the beneficial use may have.

Recommendation. Assess the existing biological resources of the environment. Existing resources should be compared vis-à-vis expected changes or enhancements in habitat/species use. Scientific confirmation that created habitat is of greater value is preferred. For endangered, juvenile, and migratory species, concrete evidence of species-habitat relationships will allow impact assessments.

\section{Artificial reef capacity}

Impact assessment. Currently, all materials produced by blasting and dredging projects are to be deposited at the artificial reef sites of New York and New Jersey. Many of the reefs closest to the Harbor are reaching capacity as viable fish habitat. Artificial reef coordinators are asking that material be taken to reefs further from the point of origin, thus increasing overall projects costs.

Recommendation. Depositing material at alternative artificial reef sites will solve this problem although it will increase overall travel distances and drive associated costs higher. To mitigate costs, the creation of nearby sites may be examined for benefits to recreational and other resources.

\section{Navigational hazards}

Impact assessment. In or near federally maintained shipping channels, the U.S. Coast Guard (USCG) prohibits placement of rock, and adequate separation away from the channels is required to avoid possible groundings of large commercial vessels. Outside the designated channels some placement of material poses a hazard to recreational boaters. Congregations of boats represent a hazard to large vessels sharing the channel.

Recommendation. Reef geometry, location, and depth need to be reviewed by the USCG to establish safe under keel clearance requirements, proper separation distances from navigation channels, and density of reef structure placements. The best method for mitigating navigation hazards is to provide the public with information describing the physical changes.

\section{Infrastructure hazards}

Impact assessment. Infrastructure hazards are similar to navigational hazards. In the case of devices constructed to reduce wave action and stabilize shoreline, material not properly assembled can become free and migrate due to waves and currents. This represents an aesthetics concern and a hazard for recreational uses. 
Recommendation. Implementing agencies may need to examine the methods by which devices are engineered. Properly securing smaller material to reduce migration into recreational areas and informing the public of significant changes in high-use areas will reduce potential hazards.

\section{Economic Issues}

Economic issues may need to be addressed in order to determine the overall feasibility of the projects. The economics of the blasting and dredging of the bedrock offer several opportunities to leverage the material for other uses without a cost penalty; however, costs are expected to increase as mitigation measures become more elaborate. Included here is a brief discussion of the economic logistics facing beneficial use projects. See Table B3 for a summary.

One of the most significant factors for decisionmakers is that of incremental cost differentials. Relative to the lowest cost option, environmental benefit may need to be weighed against project costs to determine the effective value of the use. This report does not examine the definitions of value relative to incremental costs. Specific uses can be evaluated on a case-by-case manner to ensure that the values prescribed for comparison are accurate.

Beneficial use projects transport bedrock at a variable cost dependent on haul distance. Cost benefits for beneficial use material versus quarry rock are based on the different haul costs and additional sorting fees. Transportation cost becomes almost a fixed price regardless of haul distance. Tow vessels and scows are leased on a 24-hr day; therefore, the efficiency of their use is irrelevant. For example, the projected excavation time for KVK Phase 2, Contract 2, Area A, is 1 month and 25 days, while the haul time is only 17 days to Sea Girt Reef due to downtime while vessels are being loaded. Unless haul time exceeds excavation time, there is no financial impact to the project. In shoreline projects built with upland quarry material, project economics can be demonstrated as follows:

\begin{tabular}{|l|l|l||}
\hline \multirow{3}{*}{ Material } & Armor & $\$ 30 / \mathrm{cu}$ yd (sorted) \\
\cline { 2 - 3 } & Underlayer & $\$ 25 / \mathrm{cu}$ yd (sorted) \\
\cline { 2 - 3 } & Bedding & $\$ 12 / \mathrm{cu}$ yd \\
\hline Haul & Truck or barge & $\$ 20 / \mathrm{cu}$ yd \\
\hline \multirow{2}{*}{ Placement } & Armor & $\$ 30 / \mathrm{cu}$ yd \\
\cline { 2 - 3 } & Underlayer & $\$ 20 / \mathrm{cu}$ yd \\
\hline Typical project cost in place & $\$ 65-80 /$ ton \\
\hline \hline
\end{tabular}

For projects that use dredged bedrock, costs of materials need to match quarry costs. If a suitable location for offloading material at the project site can be identified, the following costs would apply:

\begin{tabular}{||l|l||}
\hline Unload barge at dockside & $\$ 5 / \mathrm{cu}$ yd \\
\hline Sort material at dockside & $\$ 10 / \mathrm{cu}$ yd \\
\hline Load trucks and local haul & $\$ 8-9 / \mathrm{cu}$ yd \\
\hline $\begin{array}{l}\text { Typical cost for dockside barge } \\
\text { operation }\end{array}$ & $\$ 22-23 / \mathrm{cu}$ yd \\
\hline \hline
\end{tabular}




\begin{tabular}{|c|c|c|c|c|}
\hline \multicolumn{5}{|c|}{$\begin{array}{l}\text { Table B3 } \\
\text { Beneficial Use of Dredged Bedrock: Economic Issues }\end{array}$} \\
\hline \multirow[b]{2}{*}{$\begin{array}{l}\text { Beneficial Use } \\
\text { Option }\end{array}$} & \multicolumn{4}{|c|}{ Economic Issue $^{1}$} \\
\hline & $\begin{array}{l}\text { Financing } \\
\text { Increased } \\
\text { Costs }\end{array}$ & $\begin{array}{l}\text { Market Prices } \\
\text { of Material }\end{array}$ & $\begin{array}{l}\text { Increased } \\
\text { Operating } \\
\text { Costs }\end{array}$ & $\begin{array}{l}\text { Timing Issues } \\
\text { \& Associated } \\
\text { Costs }\end{array}$ \\
\hline Artificial reefs & $\mathrm{N}$ & $\mathrm{P}$ & $\mathrm{N}$ & $\mathrm{N}$ \\
\hline Oyster reefs & $\mathrm{P}$ & $\mathrm{C}$ & $\mathrm{P}$ & $\mathrm{P}$ \\
\hline Lobster reefs & $\mathrm{P}$ & $\mathrm{P}$ & $\mathrm{P}$ & $\mathrm{N}$ \\
\hline Inshore reefs & $\mathrm{P}$ & $\mathrm{P}$ & $\mathrm{C}$ & $\mathrm{P}$ \\
\hline $\begin{array}{l}\text { Sediment feeder } \\
\text { material }\end{array}$ & $\mathrm{P}$ & C & $\mathrm{P}$ & $\mathrm{P}$ \\
\hline Groins \& jetties & $\mathrm{N}$ & $\mathrm{P}$ & $\mathrm{C}$ & $\mathrm{P}$ \\
\hline Revetments & $\mathrm{N}$ & $\mathrm{P}$ & $\mathrm{P}$ & $\mathrm{P}$ \\
\hline Seawalls & $\mathrm{P}$ & $P$ & $\mathrm{C}$ & $\mathrm{P}$ \\
\hline Breakwaters & $\mathrm{P}$ & $\mathrm{P}$ & $\mathrm{P}$ & $\mathrm{P}$ \\
\hline $\begin{array}{l}\text { Wave-attenuating } \\
\text { devices }\end{array}$ & $\mathrm{P}$ & $\mathrm{P}$ & $\mathrm{P}$ & $\mathrm{P}$ \\
\hline Aggregate production & $\mathrm{N}$ & $\mathrm{C}$ & $\mathrm{N}$ & $\mathrm{P}$ \\
\hline
\end{tabular}

Placement cost for the material at the project site remains the same while the quarry delivery cost is roughly 85 to 90 percent bedrock. Benefits are thus from the actual value of the material received. The material being produced is categorized as underlayer material with a value of $\$ 45 / \mathrm{cu}$ yd. This suggests a potential positive benefit of $\$ 22 / \mathrm{cu}$ yd. This benefit would diminish if land is needed for storage and the material requires sorting. Some economics might be affected if selected sized bedrock is required, adversely affecting the unit cost of the material.

\section{Financing increased project costs}

Impact assessment. The major costs incurred with the beneficial use of dredged bedrock are due to increased time necessary to engineer uses and rehandled material. For example, current artificial reef practices are dependent on dredging methods used by the contractor to produce a least cost transport. Additional requirements imposed on improving the output of dredged rock for beneficial use may have significant costs associated with the change in methods. This requires additional project funding.

Recommendation. To overcome costs associated with changes in the production, transport, or placement, it is recommended that implementing agencies create pilot projects to ascertain the costs of beneficial use. Once costs are determined, processes can be shifted to a larger scale. Second, resource managers may prefer to adjust the timing of dredging activities to coincide with beneficial use needs. This would minimize increased storage and hauling costs of the project. 


\section{Market prices of industrial material}

Impact assessment. Aggregate markets are set at a rate that reflects the supply and demand of the materials in the market. Adding material locally impacts the market adversely by creating a large supply, consequently resulting in increased competition and lower market value. This impacts aggregate interests in the Northeast, and potentially the construction industry in general. A determination of the amount of material being excavated and the total amount of aggregate used in New York/New Jersey will allow for an assessment of shortterm market fluctuations.

Recommendation. Beneficial use projects can store material and cycle it into the supply market at regular intervals over a longer time period. This method would prevent flooding the market with aggregate, allowing the price to remain stable, benefiting long-term economic interests.

\section{Increased operating costs}

Impact assessment. One of the mandates of the Water Resources Development Act (WRDA) is that nonfederal sponsors pay the costs of maintaining beneficial use projects. Additional costs, if significant, will deter prospective sponsors from engaging in such activities. These costs can extend for the life of the project, adding uncertainty to the potential cost-sharing entity.

Recommendation. Increased costs associated with maintenance can be overcome with proper engineering of the structure. Investing in the planning process will reduce uncertainty involved with the long-term costs. Nonfederal sponsors will more likely engage in beneficial use projects.

\section{Timing issues and associated costs}

Impact assessment. If dredging schedules are not compatible with the rate of beneficial use of the material, costs would be expected to rise significantly due to increased waiting times experienced by dredgers and barge operators. This will drive up costs in contractor estimates.

Recommendation. Use of storage facilities to make material available at the rate desired by beneficial use projects allows dredging operators to schedule material loading and reduce waiting periods. This option may increase costs involved with double handling among the initial barge, storage facility, and implementation device. An alternative would use a barge operated by the nonfederal sponsor as a storage and transportation vehicle, enabling a more efficient dredging schedule.

\section{Regulatory Issues}

Regulatory issues are those resulting from conflicts with policies that directly or indirectly govern the environment of the NY/NJ Harbor. Originating from 
governing bodies at the federal, state, county, and local levels, regulations have the potential to significantly impact the implementation of beneficial use projects. Four significant regulations may affect project implementation as shown in Table B4. WRDA governs the beneficial use of all dredged material in the United States. The Endangered Species Act (ESA) and the Marine Protection, Research \& Sanctuaries Act (MPRSA) protect specific habitats and species from significant biological degradation. The Artificial Reef Plans of the states of New York and New Jersey impact uses that involve the creation of submerged habitat. There are also other regulations that affect beneficial use projects, including the London Dumping Convention, National Environmental Policy Act, Coastal Zone Management Act, and Rivers and Harbors Act 1899, that are not discussed in detail here.

\begin{tabular}{|c|c|c|c|c|c|}
\hline \multicolumn{6}{|c|}{$\begin{array}{l}\text { Table B4 } \\
\text { Beneficial Use of Dredged Bedrock: Regulatory Issues }\end{array}$} \\
\hline \multirow[b]{2}{*}{ Beneficial Use Option } & \multicolumn{5}{|c|}{ Regulatory Issue $^{1}$} \\
\hline & WRDA & ESA & $\mathrm{CWA}^{2}$ & MPRSA & $\begin{array}{l}\text { State } \\
\text { Artificial } \\
\text { Reef } \\
\text { Plans } \\
\end{array}$ \\
\hline Artificial reefs & $\mathrm{N}$ & $\mathrm{N}$ & P & $\mathrm{P}$ & $\mathrm{N}$ \\
\hline Oyster reefs & $P$ & $\mathrm{P}$ & $\mathrm{P}$ & $\mathrm{P}$ & $P$ \\
\hline Lobster reefs & $\mathrm{P}$ & $\mathrm{P}$ & $\mathrm{P}$ & $\mathrm{P}$ & $\mathrm{P}$ \\
\hline Inshore reefs & $\mathrm{C}$ & $\mathrm{P}$ & $\mathrm{C}$ & $\mathrm{P}$ & $\mathrm{N}$ \\
\hline Sediment feeder material & $\mathrm{P}$ & $\mathrm{C}$ & $\mathrm{C}$ & $\mathrm{P}$ & - \\
\hline Groins \& jetties & $\mathrm{C}$ & $\mathrm{P}$ & $\mathrm{C}$ & $\mathrm{P}$ & - \\
\hline Revetments & $\mathrm{C}$ & $\mathrm{P}$ & $P$ & $\mathrm{P}$ & - \\
\hline Seawalls & $\mathrm{C}$ & $\mathrm{P}$ & $\mathrm{P}$ & $\mathrm{P}$ & - \\
\hline Breakwaters & $\mathrm{C}$ & $\mathrm{C}$ & $\mathrm{C}$ & $\mathrm{P}$ & - \\
\hline Wave-attenuating devices & $\mathrm{P}$ & $\mathrm{P}$ & $\mathrm{C}$ & $\mathrm{P}$ & - \\
\hline Aggregate production & $\mathrm{P}$ & $\mathrm{N}$ & $\mathrm{N}$ & $\mathrm{N}$ & - \\
\hline
\end{tabular}

\section{Water Resources Development Act}

Impact assessment. The WRDA addresses the beneficial uses of all dredged material with respect to environmental impacts and cost-sharing procedures. In the NY/NJ Harbor, the most significant portions of the regulation are Sections 204 (1992) and 207 (1996). WRDA Section 204 authorizes the beneficial use of material for the protection, restoration, and creation of aquatic and ecologically related habitat, including wetlands, in connection with existing federal dredging projects for the improvement of the quality of the environment in the public interest. Section 207 (1996) authorizes the cost sharing of beneficial use projects with nonfederal agencies to reduce overall project cost to the government. What constitutes the improvement of existing habitat for the public may be construed several ways. Beneficial use projects also must engage a nonfederal sponsor in an agreement where the nonfederal implementing agency shares 25 percent of the total costs. 
Recommendation. Modeling impacts on the ecosystem and comparing with existing habitat can determine whether the costs will outweigh the benefits. Historical habitat records may be useful in validating habitat changes/improvements. Limitations produced by WRDA Section 207 (1996) on nonfederal sponsors will involve the lessening of burden by providing financial, planning, and maintenance support. This provides incentives for engaging in beneficial use projects.

\section{Endangered Species Act}

Impact assessment. ESA's mandate is to "provide a means whereby the ecosystems upon which endangered species and threatened species depend may be conserved." Impacts on beneficial use projects extend to projects that alter habitat directly used by endangered or threatened species. Habitat creation, or restoration, and shoreline stabilization projects may impact these species and thus must be reviewed.

Recommendation. All potential beneficial use projects must evaluate species that use habitat that is affected by alterations to the environment. If endangered or threatened species exist, then measures need to be taken to avoid impacts on species or habitat, and proper permits are acquired.

\section{Clean Water Act}

Impact assessment. CWA Section 404 (1972) requires permits for the placement of dredged material into the waters of the United States. This includes a provision in subsection (f) for the nonprohibited discharge "for the purpose of maintenance... of currently serviceable structures such as dikes, dams, levees, groins, riprap, breakwaters, causeways, and bridge abut or approaches, and transportation structures." All permits to allow discharge of dredged material will be reviewed for environmental consideration.

Recommendation. With any use where dredged material is "discharged" into the environment, the proper permits must be applied for from the Secretary of the Army, acting through the Chief of Engineers. After public hearing and examination, a permit for the beneficial use project may be issued.

\section{Marine Protection, Research, and Sanctuaries Act}

Impact assessment. Section 103 of MPRSA (1972) also requires permits for the placement of dredged material. Permits will be approved if deemed that "transportation of dredged material... will not unreasonably degrade or endanger human health, welfare, or amenities, or the marine environment, ecological systems, or economic potentialities." The Secretary of the Army issues permits upon public review and comment.

Recommendation. To overcome any constraints that exist, it is recommended that the proper permits be applied for with the Secretary of the Army. 
Upon review by both the public and the Secretary, the permits should be approved and the beneficial use implemented.

\section{New York and New Jersey State Artificial Reef Plans}

Impact assessment. The National Artificial Reef Plan focuses on the use of material to create and enhance fish habitat for the purpose of increased recreational fishing and diving. Recently, state reef coordinators have shown interest in the impact that reefs are having on the biological community. New York and New Jersey's Artificial Reef Plans focus on the planning and guidance of reef design, with increasing emphasis on the benefits to fishery resources.

Recommendation. The majority of the beneficial use projects of the NY/NJ Harbor concerning dredged material have been found to be in compliance with the Artificial Reef Plans of each respective state. Issues of habitat value may arise as the reefs closest to the NY Bight become saturated with material. Artificial reef coordinators may prefer that material be spread further down the coasts to more barren reef locations to improve habitat quality.

\section{Federal and Nonfederal Sponsor Institutional Issues}

Institutional issues are defined as those limitations to the implementation of beneficially using dredged bedrock that involve governmental organizations, environmental agencies, nonprofit groups, private companies, and the general public (Table B5). The major groups that factor in any beneficial use analysis include: Port Authority of New York/New Jersey (PANYNJ), USACE, U.S. Environmental Protection Agency, U.S. Fish and Wildlife Service, NMFS, NYSDEC, NJDEP, NYCDEP, NY/NJ Pilots Association, Natural Resources Defense Council, Coalition for the Bight, NY/NJ Clean Ocean and Shore Trust, NY/NJ Baykeeper, private aggregate companies, and the general public.

\section{Intraorganizational and interorganizational conflict}

Impact assessment. Within an organization, conflict may ensue from differing mandates of current projects, especially those relating to habitat creation and restoration, where existing projects may preclude the implementation of the use. Beneficial use projects may be impeded by conflicts with exterior organizations when missions, guidelines, and current projects have conflicts in interest.

Recommendation. Conflicts within an agency may be resolved through extensive conversations between the key players in their respective projects. This will give resource and project managers the opportunity to understand the ongoing projects and then propose resolutions. Being aware of infrastructure and ecosystem projects in the region is a proactive step to avoiding this conflict. 


\begin{tabular}{|c|c|c|c|c|}
\hline \multicolumn{5}{|c|}{$\begin{array}{l}\text { Table B5 } \\
\text { Federal and Nonfederal Institutional Beneficial Use Bedrock } \\
\text { Issues }\end{array}$} \\
\hline \multirow[b]{2}{*}{ Beneficial Use Option } & \multicolumn{4}{|c|}{$\begin{array}{ll}\text { Institutional Issue }^{1} \\
\end{array}$} \\
\hline & $\begin{array}{l}\text { Intra- } \\
\text { organizational }\end{array}$ & $\begin{array}{l}\text { Inter- } \\
\text { organizational }\end{array}$ & $\begin{array}{l}\text { Institutional } \\
\text { Project } \\
\text { Responsibility }\end{array}$ & $\begin{array}{l}\text { Public } \\
\text { Preferences }\end{array}$ \\
\hline Artificial reefs & N & P & P & ( N \\
\hline Oyster reefs & $\mathrm{N}$ & $P$ & $\mathrm{C}$ & $\mathrm{N}$ \\
\hline Lobster reefs & $\mathrm{N}$ & $P$ & $\mathrm{C}$ & $\mathrm{N}$ \\
\hline Inshore reefs & $P$ & $P$ & $P$ & $P$ \\
\hline $\begin{array}{l}\text { Sediment feeder } \\
\text { material }\end{array}$ & $P$ & C & $P$ & C \\
\hline Groins \& jetties & $P$ & $\mathrm{C}$ & $\mathrm{P}$ & $\mathrm{C}$ \\
\hline Revetments & $\mathrm{N}$ & $P$ & $P$ & $\mathrm{~N}$ \\
\hline Seawalls & $\mathrm{P}$ & $\mathrm{C}$ & $\mathrm{P}$ & $\mathrm{C}$ \\
\hline Breakwaters & $\mathrm{P}$ & $\mathrm{P}$ & $\mathrm{P}$ & $\mathrm{C}$ \\
\hline $\begin{array}{l}\text { Wave-attenuating } \\
\text { devices }\end{array}$ & C & C & C & $\mathrm{P}$ \\
\hline Aggregate production & $\mathrm{N}$ & $\mathrm{C}$ & $\mathrm{P}$ & $\mathrm{N}$ \\
\hline
\end{tabular}

\section{Institutional project responsibility}

Impact assessment. WRDA includes a provision that allows for multiple agencies to share responsibility for the implementation. The USACE may need to coordinate the logistics of the operations, the financial funding of the projects, and the ownership/maintenance to ensure project completion.

Recommendation. Managing the shared responsibility of any given beneficial use project will involve extensive communication and planning by all agencies and organizations involved. Including proper personnel in the planning stages reduces the risk of increased project costs.

\section{Public preferences}

Impact assessment. Public opinion, often represented by nonprofit and civic organizations, will affect beneficial use projects and organizations. In the case of shore protection devices, the use of nonnative materials may cause community opposition and reduced public opinion of an agency. Public concern can highly constrain the opportunities driven by the engineering methods as in the case of changing blasting patterns to produce material better suited for beneficial use. Negative consequences to surrounding properties include cracked walls in homes, broken chimneys, and fractured water lines. Where the intended function is to stabilize the water edge from erosion, the aesthetics and utility of the site might be altered with the introduction of shore protection devices.

Recommendation. Include the community in the planning process. Providing local stakeholders ownership of the project's intended benefit and providing an avenue for input into the project may increase public acceptance of the project. In addition, the proper planning and communications processes should 
increase the public's perception of governmental organizations involved with the project. The ultimate opportunity to use the material for erosion protection in heavily populated areas may be determined by the public's interests.

\section{Engineering Issues}

Engineering issues affect the logistics of an operation, which consequently impact resource use, including human and machinery allocated for the project and project costs as illustrated in Table B6.

\begin{tabular}{|c|c|c|c|c|c|}
\hline \multicolumn{6}{|c|}{$\begin{array}{l}\text { Table B6 } \\
\text { Beneficial Use of Dredged Bedrock: Engineering Issues }\end{array}$} \\
\hline \multirow[b]{2}{*}{$\begin{array}{l}\text { Beneficial Use } \\
\text { Option }\end{array}$} & \multicolumn{5}{|c|}{$\begin{array}{ll}\text { Engineering Issue }^{1} \\
\end{array}$} \\
\hline & $\begin{array}{l}\text { Blasting \& } \\
\text { Dredging } \\
\text { Practices }\end{array}$ & $\begin{array}{l}\text { Processing } \\
\text { \& Sorting } \\
\text { Facilities }\end{array}$ & $\begin{array}{l}\text { Storage } \\
\text { Capacity }^{2}\end{array}$ & $\begin{array}{l}\text { Rehandling } \\
\text { Issues }\end{array}$ & $\begin{array}{l}\text { Material } \\
\text { Suitability }\end{array}$ \\
\hline Artificial reefs & $\mathrm{N}$ & $\overline{\mathrm{N}}$ & $\overline{\mathrm{N}}$ & $\overline{\mathrm{N}}$ & $\mathrm{N}$ \\
\hline Oyster reefs & $P$ & $P$ & $\mathrm{C}$ & C & $P$ \\
\hline Lobster reefs & $P$ & $\mathrm{P}$ & $\mathrm{C}$ & $\mathrm{C}$ & $\mathrm{N}$ \\
\hline Inshore reefs & $P$ & $\mathrm{P}$ & $\mathrm{P}$ & $\mathrm{C}$ & $\mathrm{P}$ \\
\hline $\begin{array}{l}\text { Sediment feeder } \\
\text { material }\end{array}$ & $P$ & $\mathrm{C}$ & $N$ & $P$ & $P$ \\
\hline Groins \& jetties & $\mathrm{C}$ & $\mathrm{P}$ & $P$ & $\mathrm{C}$ & C \\
\hline Revetments & $P$ & $P$ & $P$ & $P$ & $P$ \\
\hline Seawalls & $\mathrm{P}$ & $P$ & $P$ & $\mathrm{C}$ & $P$ \\
\hline Breakwaters & $\mathrm{P}$ & $\mathrm{P}$ & $P$ & $\mathrm{P}$ & $\mathrm{P}$ \\
\hline $\begin{array}{l}\text { Wave-attenuating } \\
\text { devices }\end{array}$ & $P$ & C & $P$ & c & $P$ \\
\hline $\begin{array}{l}\text { Aggregate } \\
\text { production }\end{array}$ & $P$ & $P$ & C & C & $\mathrm{N}$ \\
\hline
\end{tabular}

The beneficial use of dredged bedrock involves extensive coordination and planning with engineering organizations. Limiting the number of viable options to explore at that level will decrease costs involved with project implementation.

\section{Blasting/dredging practices}

Impact assessment. Currently, rock is blasted with high-impact explosives and then brought to the surface by means of clamshell dredgers. The material is then loaded onto barges for marine transport to artificial reefs. The issues of blasting and dredging bedrock include minimizing the explosion shock wave propagating into adjacent shoreline structures, minimizing calendar time involved in the blasting procedures, and producing fractured rock sizes that are easily excavated. Producing selectively sized materials can have negative impacts on production processes, affecting clamshell dredgers' ability to remove bedrock. Resulting smaller material may not be able to be used in projects that require a larger bedrock. 
Recommendation. Blasting rock with heavy explosives and dredging with clamshell buckets is a process tailored towards minimizing operating costs. A shift from the current production process may call for a shift in technologies. Different levels of explosives may create larger or smaller pieces of rock. Examining the excavation technique of rock produced in future phases might reveal that other dredging methods allow for a better production of usable material sizes and shapes. Another concern is the effects that changing the blasting methodologies would have on fish with air-filled swim bladders. Timing blasts properly to limit the impact on the aquatic wildlife may have the potential to offset this concern.

\section{Processing/Sorting/Storage Facilities}

Impact assessment. In the case of dredged bedrock, there are two components to any land-based processing facility. The first component would be the sorting of material for characteristics including rock size, geological specification, and material durability. The second component is the processing capability of the implementing beneficial use agency. Storage capacity of dredged bedrock is also an issue. The elevated real estate values in New York make it difficult to locate affordable facilities. The inability of beneficial use projects to store material limits the window of opportunity.

Recommendation. Purchase and operation of facilities for sorting, processing, and sorting bedrock by the USACE in the vicinity relatively near to dredged waterways will allow for more uses to become viable options. Presuming that a single ownership can be established, a properly positioned facility would allow for the transfer of material from contractors' barges directly to sorting machinery. An alternate approach would be the creation of a privatepublic partnership with local aggregate companies whereby a private company would receive, sort, and process material and keep the material for a nominal cost. The USACE could retain or transfer ownership rights of the material dependent on intended beneficial use or owner. Sorted materials could be processed further in order to create a usable end product. USACE could receive royalties from the sale of the material in some instances.

The majority of beneficial use projects take significantly longer to implement than dredging operations. Construction of storage facilities would allow for beneficial use projects to be implemented over a longer time period. As an example, typical aggregate operations will produce $1,800 \mathrm{cu}$ yd of material per day (12-hr operation) while the production rate of material coming from the channel dredging is approximately 4,000 cu yd per day (24-hr operation). Delivery rate is greater than capacity of the facility to process the material, and it will be necessary to have overflow capacity. Quarry operations require 5 acres of land for processing of material plus additional area for stockpiling rock. For cost efficiency, this will need to be located essentially at the source, having a dockside location so that the material can be moved straight from the barge to storage or processing piles. The costs of a typical rock-sorting operation should be roughly the same regardless of whether the process is performed at an upland quarry or performed dockside. The upland quarry ideally may be operated in a more controlled fashion to produce material of select sizes for a specific need and 
time while the current blasting produces a broader mixture of sizes requiring more tons of material to be sorted.

The haul cost of the dredged material is nearly a constant for haul distances up to 60 miles one way. The cost to offload the barge at a convenient dock location is $\$ 5 / \mathrm{cu}$ yd. Sorting into size classifications is $\$ 10 / \mathrm{cu}$ yd. Reloading trucks for a local haul is $\$ 3 / \mathrm{cu} y d$, and the local haul cost is $\$ 5$ to $\$ 6 / \mathrm{cu} y d$, for a total cost of $\$ 22$ to $\$ 23 / \mathrm{cu}$ yd. The typical delivered price, before placement, of a quarried material is $\$ 45$ to $\$ 50 / \mathrm{cu}$ yd. Therefore, there can be a potential of a $\$ 22$ to $\$ 27 / \mathrm{cu}$ yd benefit in the use of the dredged rock. Rock may have to be sorted and offloading facilities constructed, adding cost to the project.

\section{Rehandling Issues}

Impact assessment. Rehandling refers to the processes of moving dredged material from the primary barge to other barges or to land-based locations. Rehandling adds time, cost, and additional infrastructure and facility needs to the excavation process. Current dredging practices in the KVK and AK utilize splithull barges for the transportation and placement of rock directly at the artificial reefs of New York and New Jersey. The bottom of the barge hull opens and allows a free release of the contents. Barges are loaded in a deep channel and emptied in deep water, where the barge capacity and draft can be maximized, reducing the number of trips involved. From a cost function, the use of these barges reduces costs associated with the placement of material. These types of barges, however, make it very difficult to "rehandle" material for other uses. To attempt to use the material in almost any mode other than the free release of the material entails a second step of extracting the rock from a barge. Restricted water depths at many docksides might limit haul barge drafts, forcing the barges to be only partially loaded and thus increasing the number of required trips. Time periods required to move materials from active barges to upland facilities or locations are relatively long, increasing the length that the barge is in use and thereby increasing costs.

Recommendation. Engineering constraints to beneficial use may be reduced if dredging operators use barges with different layouts. Changing from a split-hull barge to one with a flatter surface will enable an easier transfer of material from barge to land. Another benefit this change may produce is the ability to use barges of lesser draft, allowing for transportation of material to shallower channels. The setup of efficient infrastructure for moving materials, such as belt conveyers, will result in an increase of the rate by which material may be moved. The incremental difference in haul cost to the offshore disposal sites versus a haul cost to a nearby dock must be compared to the additional cost of rehandling the material onto the dock, and the associated storage of the material. 


\section{Suitability of Material}

Impact assessment. Material suitability is the most integral factor to the successful use of dredged bedrock. Factors include rock shape and size, geological characteristics, material durability/hardness, and the degree of bedrock fracturing, among others. Rock shape and size are a major issue if material is not of a preferable size for beneficial use. Similarly, the geological type and characteristics of the material may cause the rock to become unusable in different beneficial use applications.

Recommendation. While the type and characteristic of the rock material cannot be altered, there are certain steps that can be taken to limit the extent to which resources are inefficiently utilized in the implementation of each beneficial use option. In the case of determining beneficial suitability, having geologists regularly examine the bedrock material being produced will ensure that the correct materials are being allocated for the proper uses. Accurate coring information will aid in the prediction of rock material characteristics, allowing for longterm beneficial use planning. The true suitability of material of a given size and type is also a matter of cost. Assuming an adequate supply of armor stone, most likely of smaller than ideal size, an alternate structural design can be formulated using the material, but with the consequence of requiring a greater volume of that material. See Appendix A for more information. 


\section{Appendix C Decisionmaking Tools and Framework Overview}

\section{Introduction}

Using decision models to analyze the viability of the beneficial use material will conserve planning resources of the federal and nonfederal implementing agencies. When evaluating options there are two currently accepted methods of analysis. The primary method is composed of the following criteria (Battelle 1996): human and ecological benefits, compatibility of estuary or watershed goals, availability of funding mechanisms, environmental impacts, legal authority, public acceptance, and risk and uncertainty of implementation. The alternative method uses the input of various stakeholders to achieve consensus on project goals and benefits. While this approach elicits a more responsive action, it will also require more time in the short term. Major components of this method are (Battelle 1996): involvement of multiple stakeholders, recommendations communicated via stakeholder representatives, organization of recommendations into functional groups, creation of focused beneficial use goals, and stakeholder review. For the beneficial use of dredged bedrock in the NY/NJ Harbor, a combination of the methods was applied. The results of the stakeholders proceedings can be found throughout this document in text boxes adjacent to each respective section.

Figures $\mathrm{C} 1-\mathrm{C} 12$ are designed to assist decisionmakers in determining which options are viable for the use of dredged bedrock and allow for a relatively basic assessment of existing material. For further details on each option, refer to the screening level analysis (Chapter 3). To effectively use the decisionmaking diagrams presented in this appendix, it is important that the user understand the definitions and context of the process. The following paragraphs outline how each flowchart assists in determining potential beneficial uses and also provides a hypothetical case study for reference.

Figure $\mathrm{C} 1$ describes the overall choices and decisions involved in determining applicable beneficial use options including the major issues to be addressed. Figure $\mathrm{C} 1$ also links to further decisionmaking tools for geological specifications and implementation issues, Figures $\mathrm{C} 2$ and $\mathrm{C} 7$, respectively. Figure $\mathrm{C} 2$ describes the geological issues to beneficial use implementation: 
material type, material size, rock characteristics, and volume. Guidelines for each class may be found in Figures C3-C6. These solutions address the alternatives available for beneficial use. The overview of beneficial use issues includes decisionmaking information regarding engineering, environmental, regulatory, institutional, and economic limitations, and can be found in Figures C8-C12, respectively.

\section{Example Case Study: Beneficial Use Decisionmaking}

Project Planner A is in the process of managing a dredging initiative in Deepwater Channel in a metropolitan city in the United States. She is informed that there will be bedrock material produced as part of the dredging process, and the material needs to be used in a beneficial manner if possible. Project Planner A uses this decisionmaking framework as follows. First, the potential dredged bedrock material is analyzed for geological specifications. Upon analysis, the majority of the material is found to be of these characteristics: bedrock material type, 95 percent shale; postblast dredge size, 0.34 to $3 \mathrm{ft}$ in diameter; material characteristics, fair durability; bedrock volumes, less than $25,000 \mathrm{cu}$ yd. Project Planner A then sets the above parameters on a grid against the beneficial use options available utilizing the information presented in Figures $\mathrm{C} 3-\mathrm{C} 6$ as follows.

\begin{tabular}{||l|l|l|l|l|l||}
\hline \multicolumn{6}{||}{ Grid of Potential Beneficial Options Available } \\
\hline \hline $\begin{array}{l}\text { Geological } \\
\text { Characteristic }\end{array}$ & $\begin{array}{l}\text { Material } \\
\text { Type: } \\
\text { Shale }\end{array}$ & $\begin{array}{l}\text { Material } \\
\text { Size: } \\
\text { Medium }\end{array}$ & $\begin{array}{l}\text { Material } \\
\text { Durability: } \\
\text { Fair }\end{array}$ & $\begin{array}{l}\text { Material } \\
\text { Volumes: } \\
\text { Minor }\end{array}$ & $\begin{array}{l}\text { Potential } \\
\text { Use? }\end{array}$ \\
\hline \hline Artificial reefs & + & + & + & + & $\checkmark$ \\
\hline Oyster reefs & + & + & & + & \\
\hline Lobster reefs & + & + & + & + & $\checkmark$ \\
\hline Inshore reefs & + & + & & + & \\
\hline Groins \& jetties & & + & + & & \\
\hline Revetments & + & + & + & + & $\checkmark$ \\
\hline Seawalls & & & & & \\
\hline Breakwaters & & & + & & $\checkmark$ \\
\hline $\begin{array}{l}\text { Wave-attenuating } \\
\text { devices }\end{array}$ & + & + & + & + & \\
\hline $\begin{array}{l}\text { Aggregate } \\
\text { production }\end{array}$ & & + & & + & \\
\hline $\begin{array}{l}\text { Sediment feeder } \\
\text { material }\end{array}$ & + & & + & + & \\
\hline
\end{tabular}

With shale material, being of medium postdredge size, fair durability, and in minor volumes, the most applicable uses would then be artificial reefs, lobster reefs, revetments, and wave-attenuating devices. Once the potential beneficial use options are established, Project Planner A goes forward with the issue analysis to implement the feasible alternatives. Using the information presented 
in Figures C8-C12, Project Planner A evaluates the limitations of the potential uses. In the case of lobster reefs, the issues would be as follows:

- Engineering: None

- Environmental: Navigational and infrastructure hazards

- Economic: None

- Regulatory: Artificial Reef Plans of New York and New Jersey

- Institutional: Project responsibility

Project Planner A addresses the costs to mitigate the environmental, regulatory, and institutional project limitations and weighs them against the potential benefit of the project. Deciding that the benefits are greater than the costs, including mitigated constraints, Project Planner A decides to proceed with the planning and design of a lobster reef. 


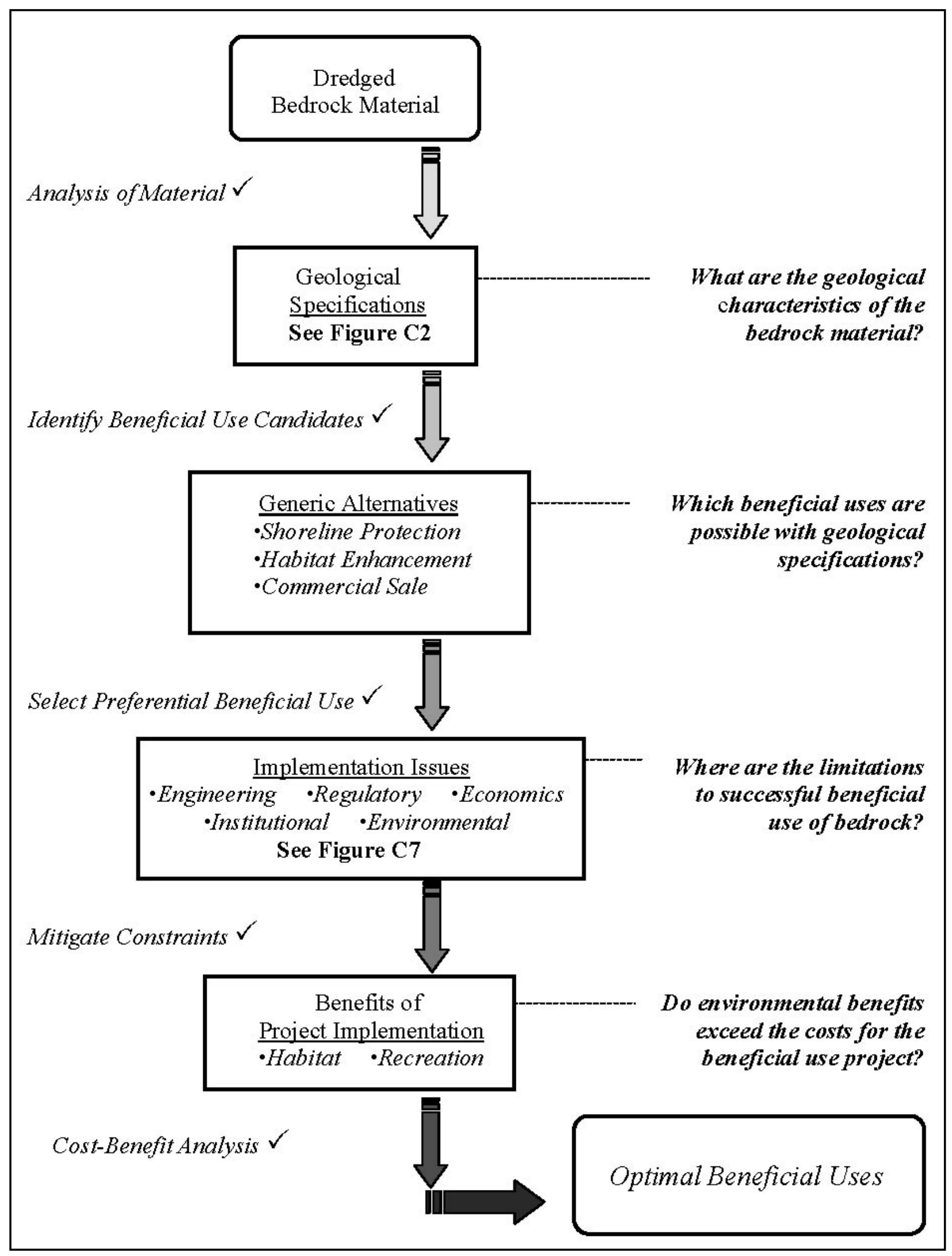

Figure C1. Beneficial use decisionmaking 


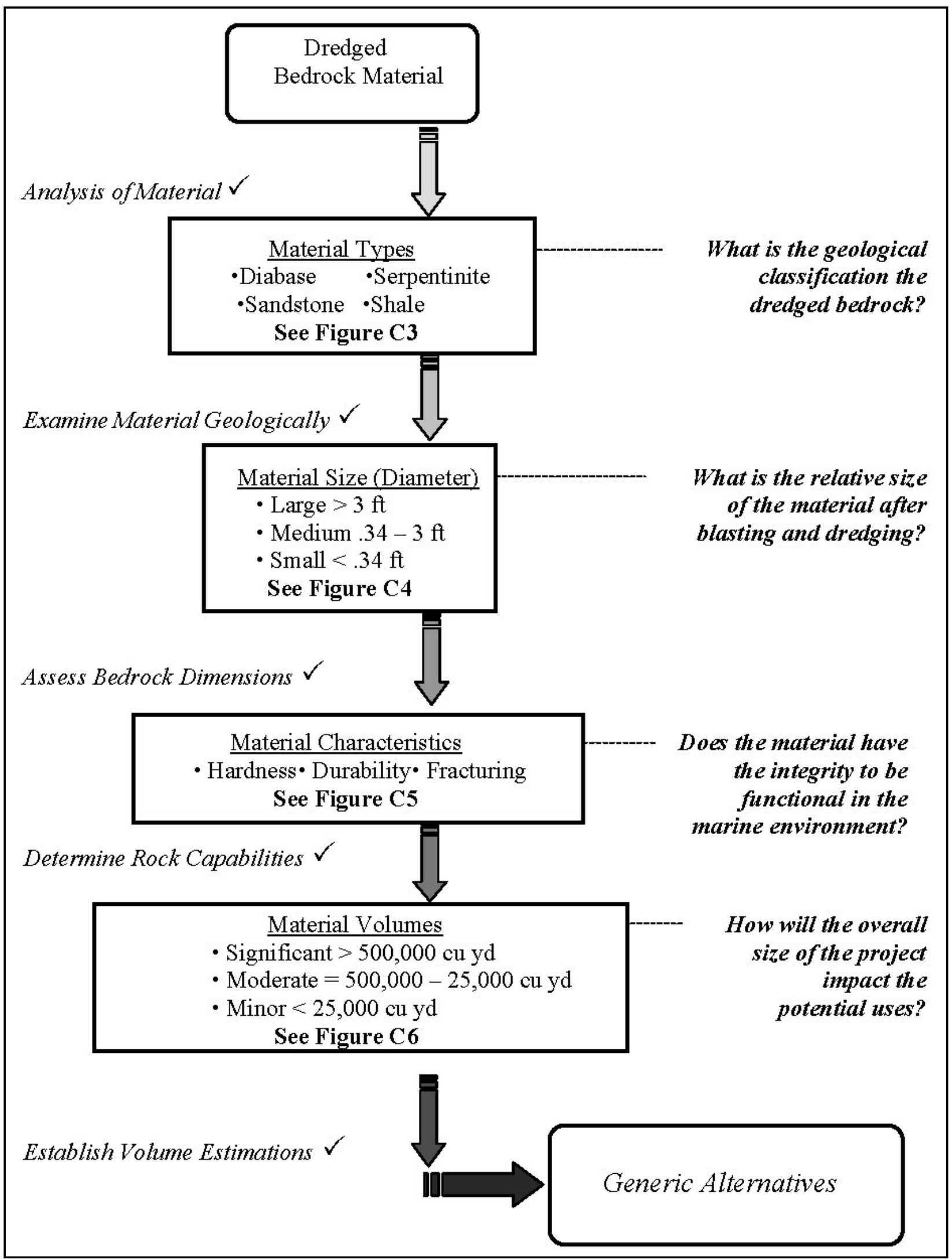

Figure C2. Geological specifications 


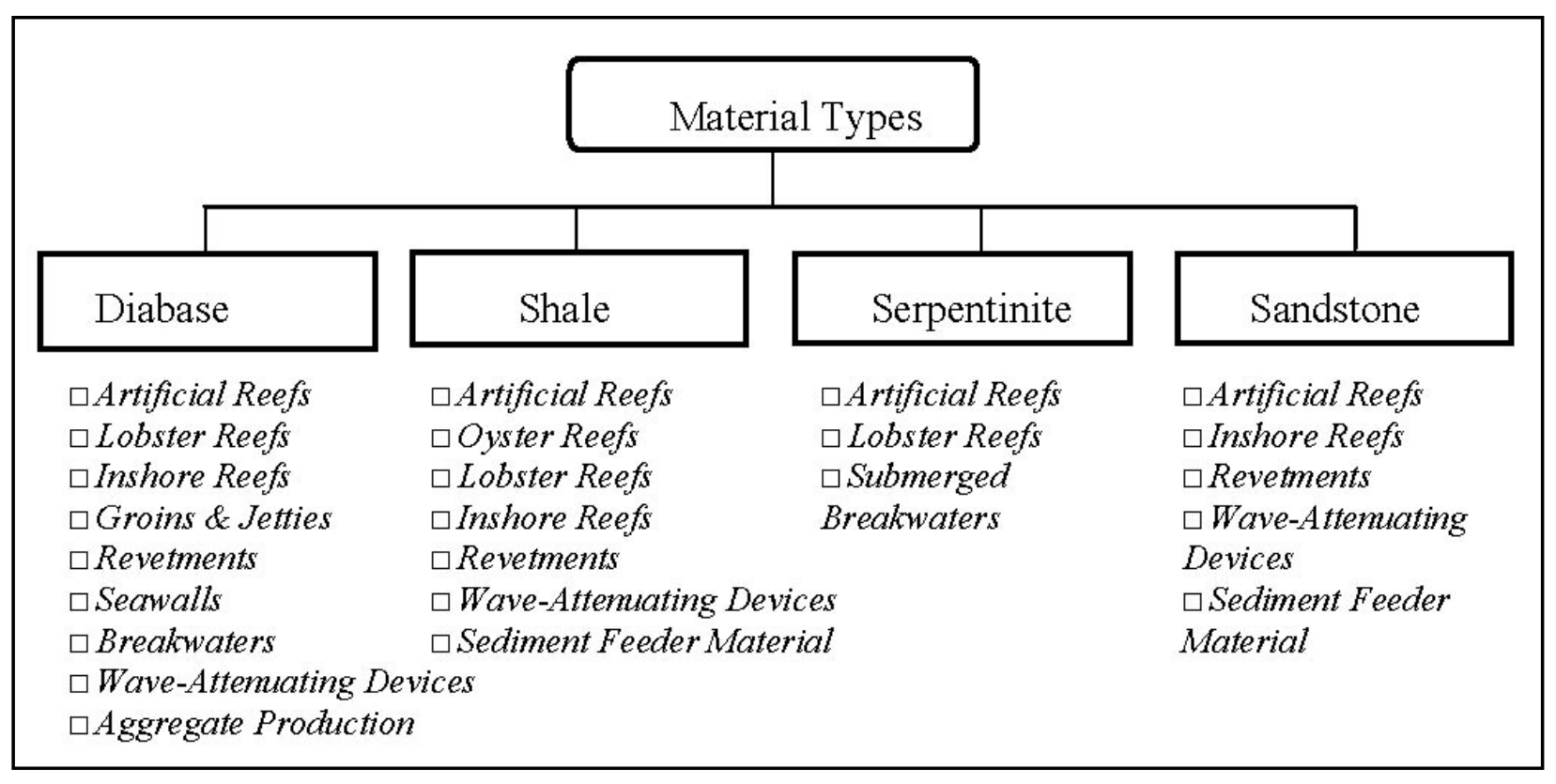

Figure C3. Alternatives for beneficial use based on material types

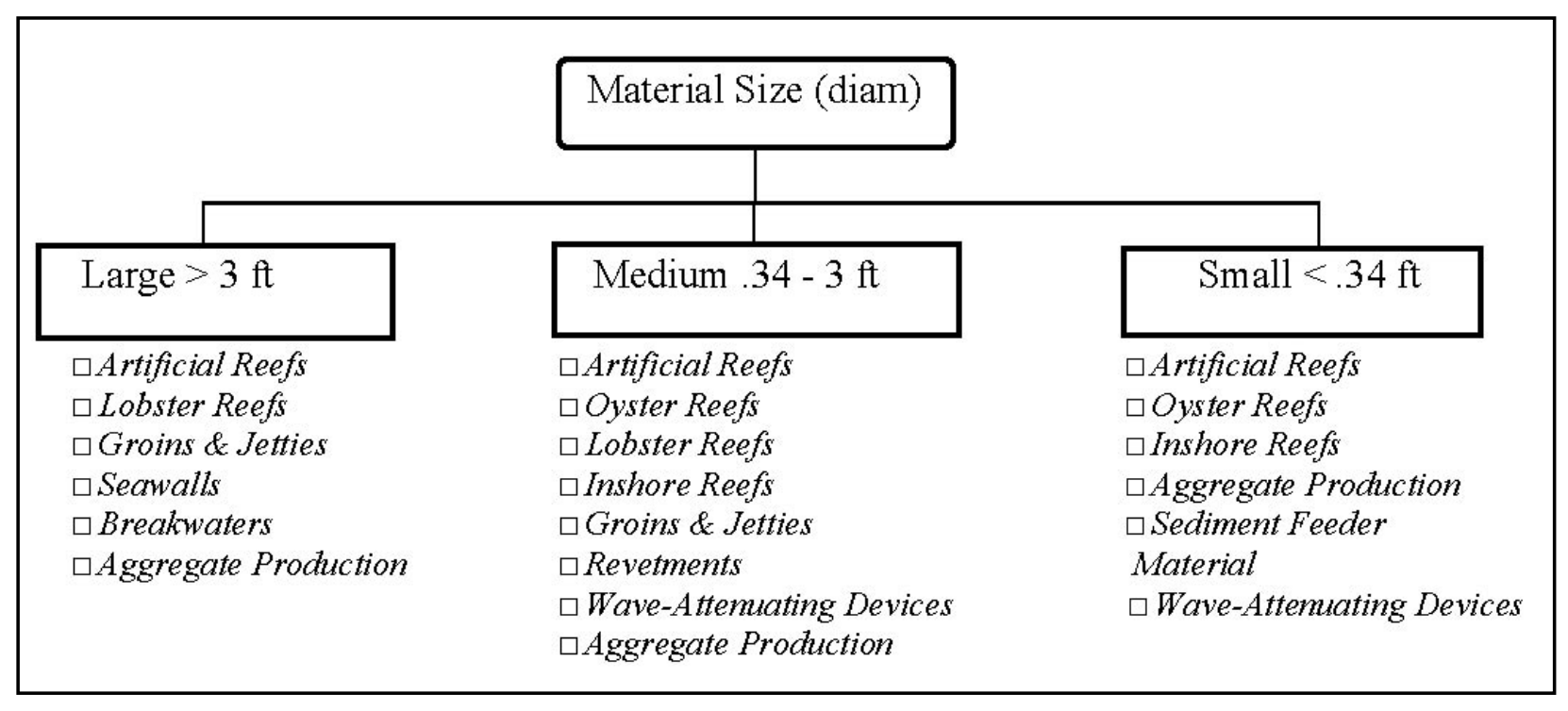

Figure C4. Alternatives for beneficial use based on material sizes 


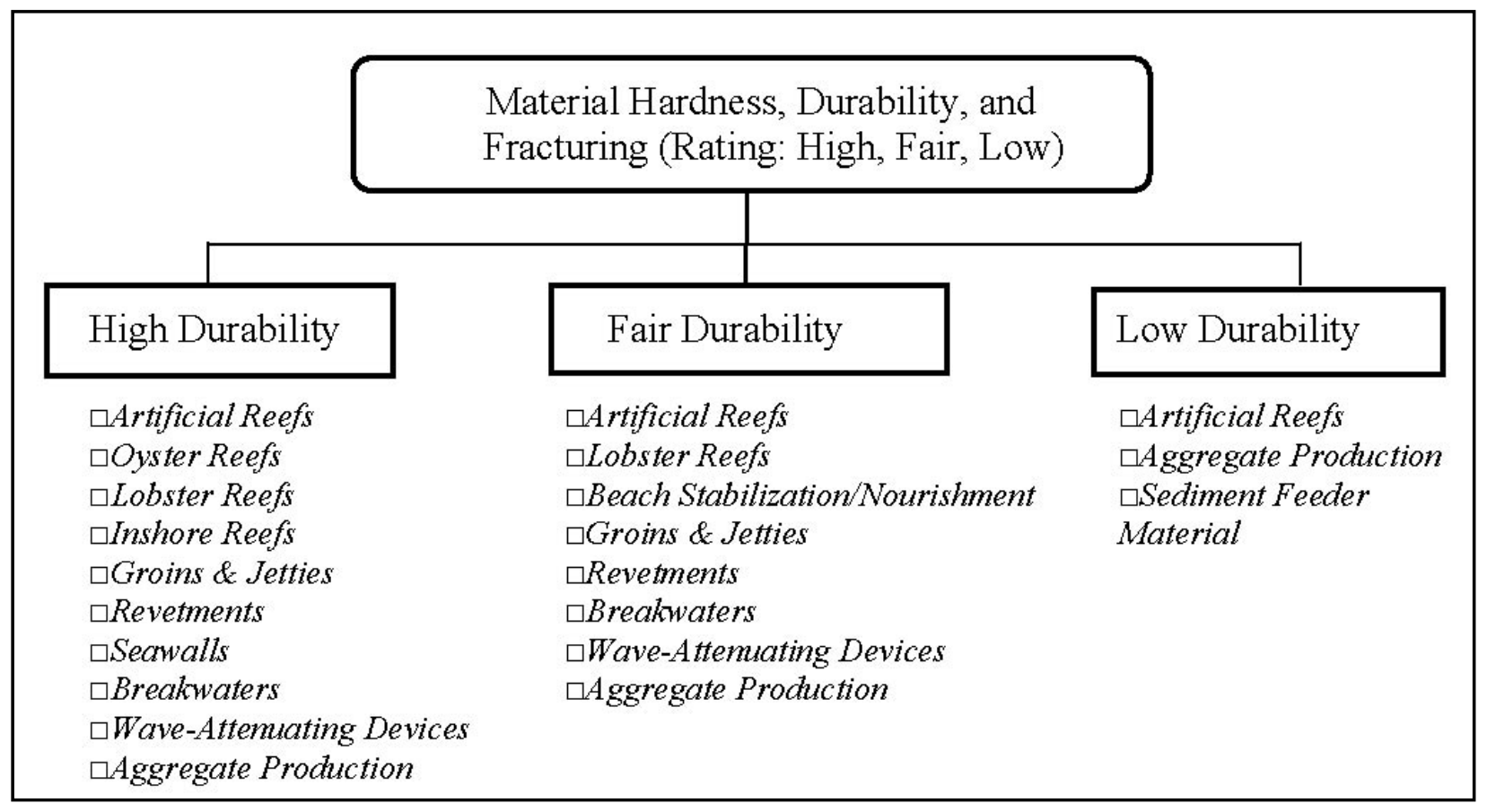

Figure C5. Alternatives for beneficial use based on hardness, durability, and fracturing

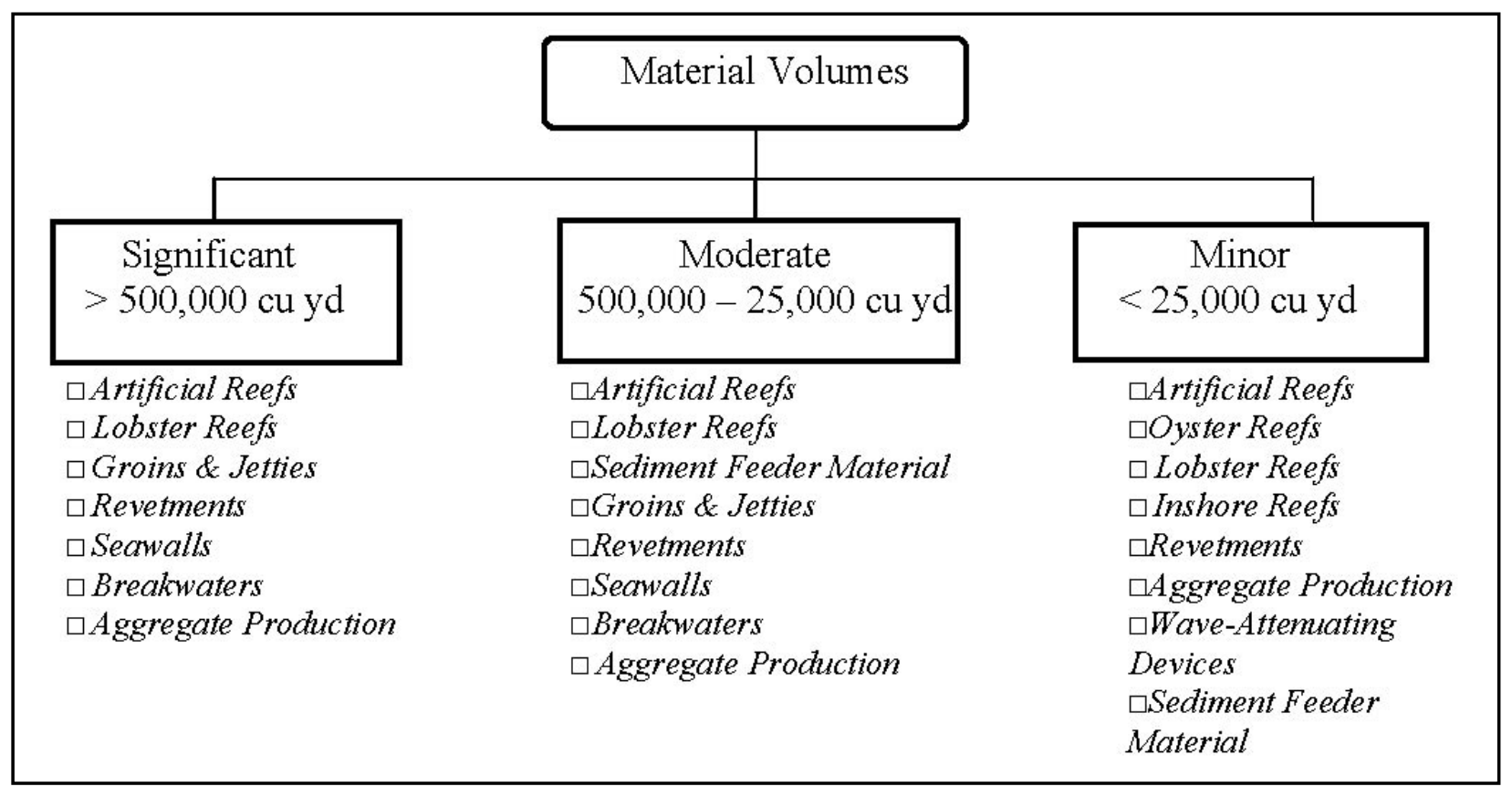

Figure C6. Alternatives for beneficial use based on material volumes 
Generic Alternative

Beneficial Uses

Compile Candidate Selections $\checkmark$

$\sqrt{5}$

Engineering Issues

- Blasting and Dredging Practices - Rehandling Issues

- Processing and Sorting Facilities - Material Suitability

- Storage Capacities

See Figure C8

How will the operational logistics affect implementation?

Address Engineering Issues $\checkmark$

Environmental Issues

- Ecosystem Impacts

What are the

- Navigational Hazards

- Reef Capacities

- Infrastructure Hazards adverse impacts

See Figure C9 occur with use?

Mitigate Habitat Degradation

Regulatory Issues

- Water Resources and Development Act (WRDA)

- Clean Water Act (CWA) - Endangered Species Act (ESA)

- Marine Protection, Research \& Sanctuaries Act (MPRSA)

- NY \& NJ State Artificial Reef Plans

See Figure C10

Procure Required Permits $\checkmark$

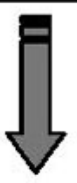

Figure C7. Issues-based decisionmaking (Continued) 


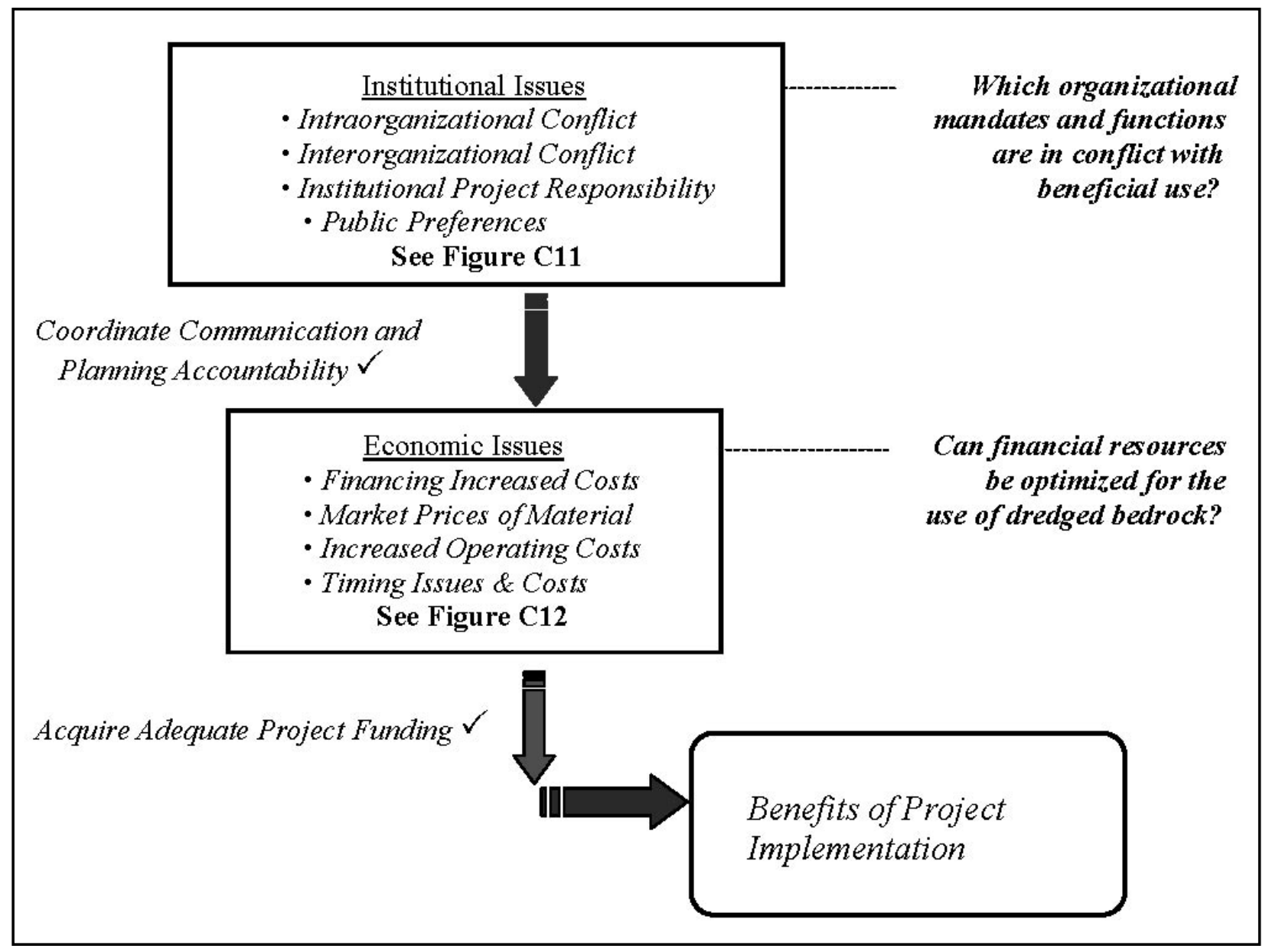

Figure C7. (Concluded) 


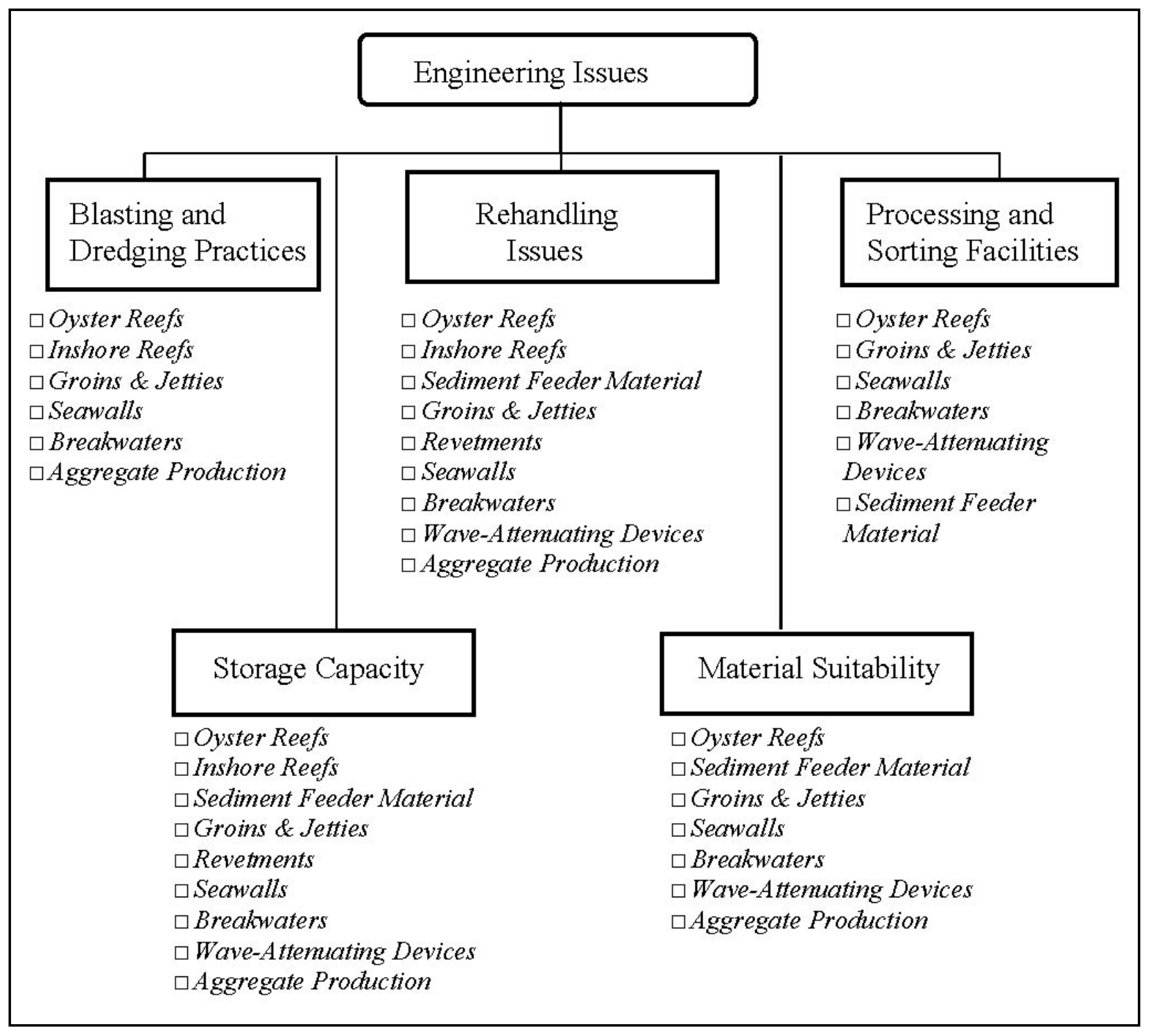

Figure C8. Applications significantly limited by engineering issues 


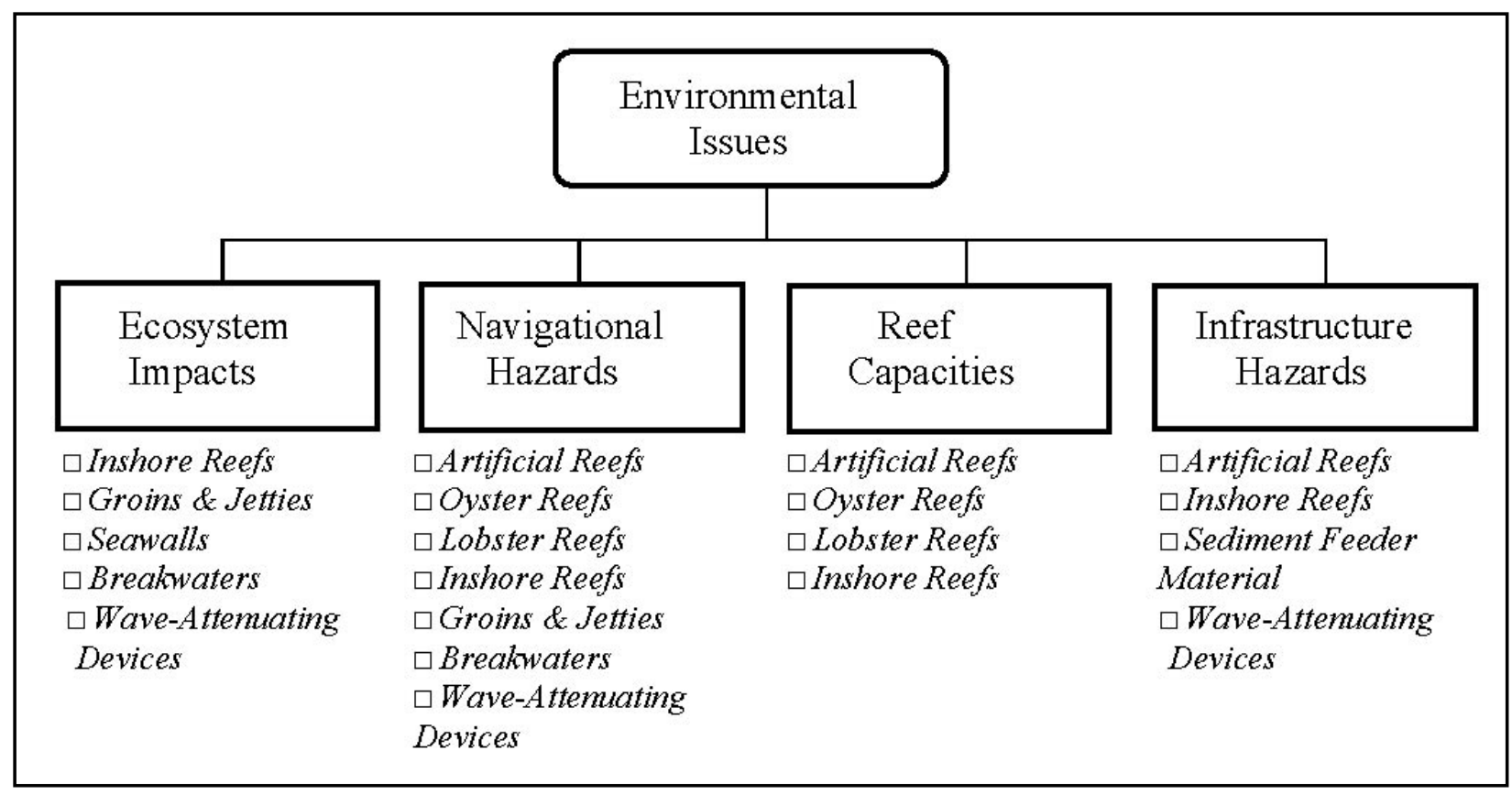

Figure C9. Applications significantly limited by environmental issues

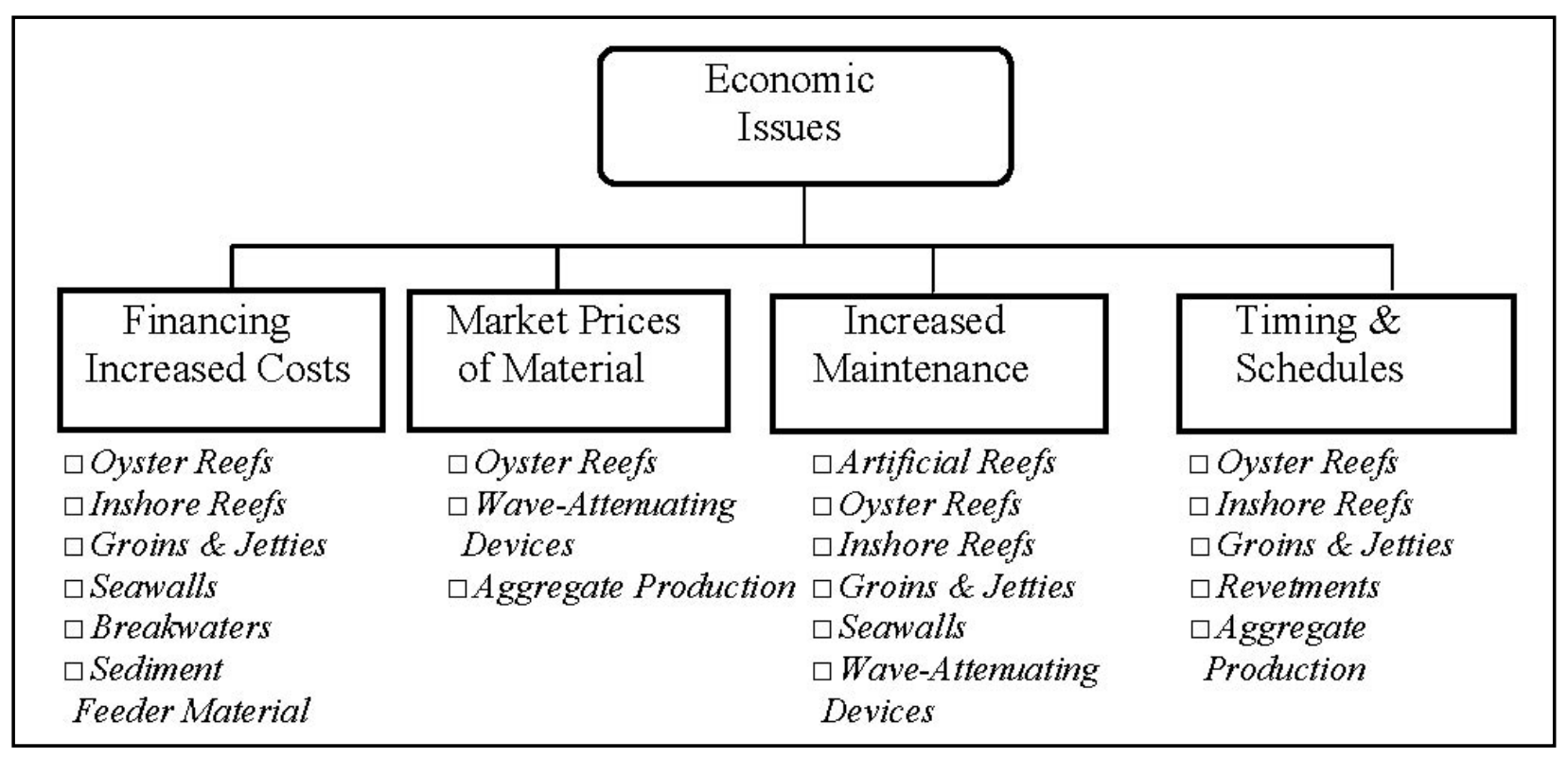

Figure $\mathrm{C} 10$. Applications significantly limited by economic issues 


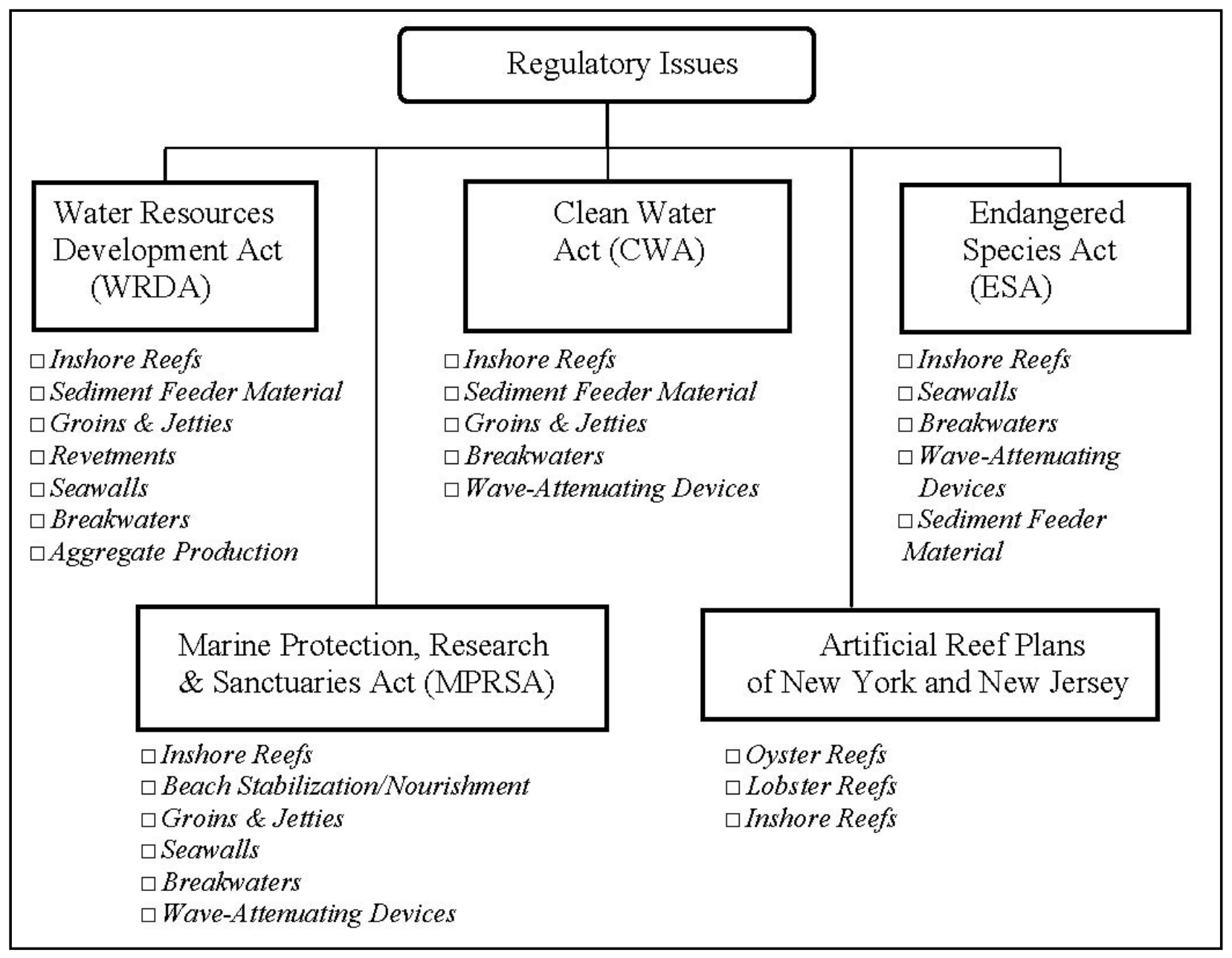

Figure C11. Applications significantly limited by regulatory issues 


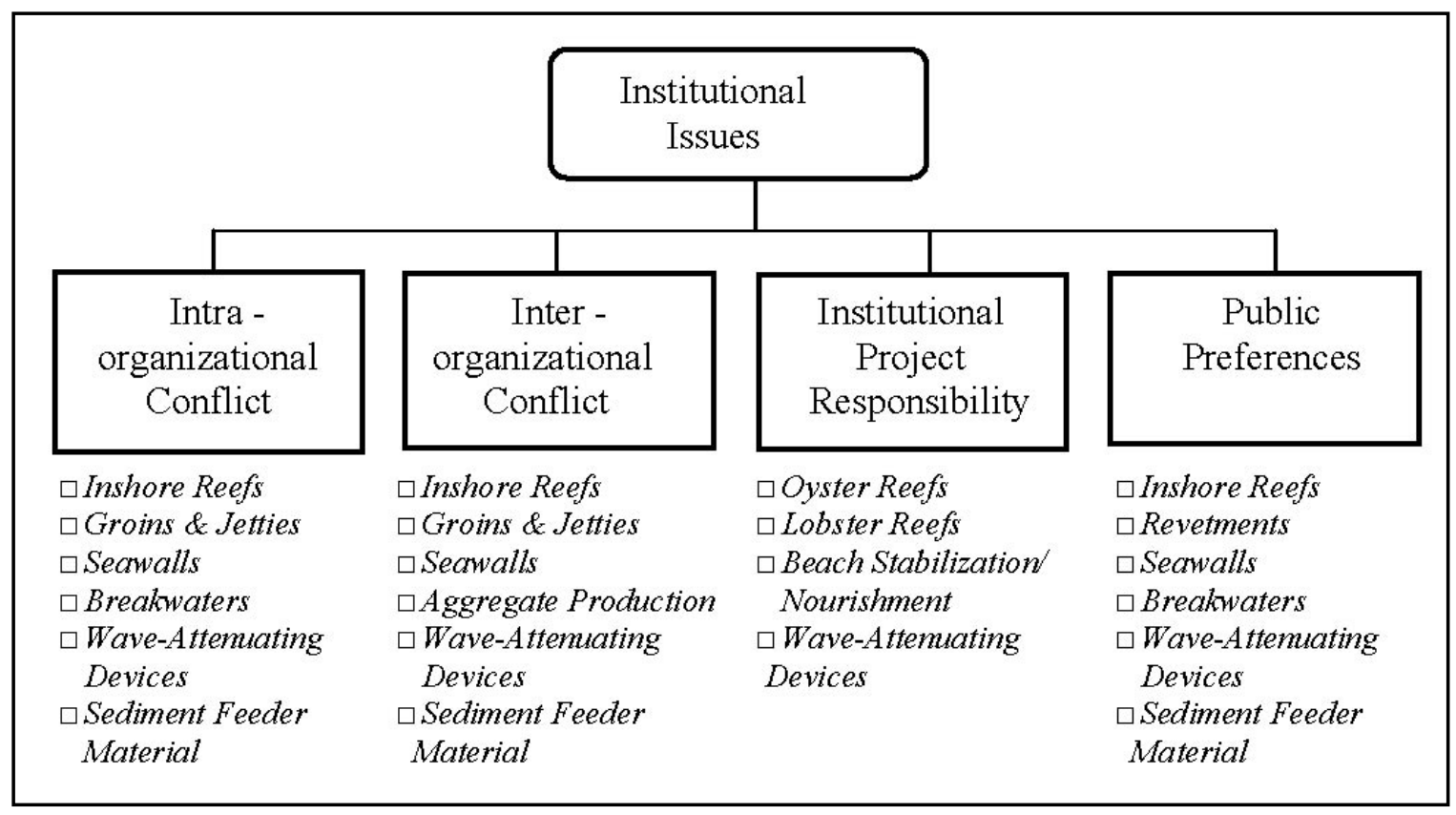

Figure C12. Applications limited by institutional federal and nonfederal issues 


\section{Appendix D \\ Vessel-Generated Wave Calculations}

\begin{tabular}{|c|c|c|c|}
\hline \multicolumn{4}{|c|}{ Tugboat-Generated Wave Heights } \\
\hline Tug Characteristics & \multicolumn{3}{|c|}{ Atlantic Elm: http://www.atlantictow.nb.ca/ } \\
\hline \multicolumn{4}{|c|}{ Sorenson and Weggel (1984) } \\
\hline \multicolumn{4}{|l|}{ Required Data } \\
\hline$V=$ Ship speed & 5 knots & $8.439 \mathrm{ft} /$ second & $5.754 \mathrm{mph}$ \\
\hline $\mathrm{d}=$ Water depth & \multicolumn{3}{|c|}{$40 \mathrm{ft}$} \\
\hline $\begin{array}{c}x=\text { Distance from sailing line to the point } \\
\text { where the wave height is measured }=\end{array}$ & \multicolumn{3}{|c|}{$300 \mathrm{ft}$} \\
\hline Vol = Volume of water ship displaced $=$ & 400 tons & \multicolumn{2}{|c|}{$12500 \mathrm{cu} \mathrm{ft}$. } \\
\hline \multicolumn{4}{|l|}{ Dimensionless Variables } \\
\hline Froude Number $=$ & 0.23514 & \multicolumn{2}{|c|}{$0.2<\mathrm{F}<0.8, \mathrm{~F}$ must fall between } \\
\hline Distance from sailing line $=x^{*}=$ & \multicolumn{3}{|c|}{12.93067} \\
\hline Depth $=d^{*}=$ & \multicolumn{3}{|c|}{1.72409} \\
\hline \multicolumn{4}{|l|}{ Calculations } \\
\hline beta $=$ & \multicolumn{3}{|c|}{-0.61890} \\
\hline delta $=$ & \multicolumn{3}{|c|}{-0.19755} \\
\hline $\mathrm{n}=$ & \multicolumn{3}{|c|}{-0.37326} \\
\hline$a=$ & \multicolumn{3}{|c|}{-2.55162} \\
\hline$b=$ & \multicolumn{3}{|c|}{3.82216} \\
\hline$c=$ & \multicolumn{3}{|c|}{-1.32614} \\
\hline LOG (alpha) = & \multicolumn{3}{|c|}{-1.72166} \\
\hline alpha $=$ & \multicolumn{3}{|c|}{0.01898} \\
\hline$H^{*}(1984)=$ & \multicolumn{3}{|c|}{0.00730} \\
\hline$H^{*}(1987)=$ & \multicolumn{3}{|c|}{-0.00237} \\
\hline \multicolumn{4}{|l|}{ Solution } \\
\hline Ship-generated wave height $=\mathrm{H}=$ & $0.2 \mathrm{ft}$ & 1984 & \\
\hline Ship-generated wave height $=\mathrm{H}=$ & $-0.1 \mathrm{ft}$ & 1987 & \\
\hline Period $=\mathrm{T}=$ & $1.3 \mathrm{sec}$ & & \\
\hline
\end{tabular}




\begin{tabular}{|c|c|c|c|c|}
\hline \multicolumn{5}{|c|}{ PIANC (1987) } \\
\hline \multicolumn{5}{|l|}{ Required Data } \\
\hline$V=$ Ship speed & 10 knots & \multicolumn{3}{|c|}{$16.878 \mathrm{ft} / \mathrm{sec}$} \\
\hline $\mathrm{d}=$ Water depth & \multicolumn{4}{|c|}{$40 \mathrm{ft}$} \\
\hline $\begin{array}{l}x=\text { Distance from sailing line to the point } \\
\text { where the wave height is measured }=\end{array}$ & \multicolumn{4}{|c|}{$300 \mathrm{ft}$} \\
\hline Breadth $=$ & \multicolumn{4}{|c|}{$30 \mathrm{ft}$} \\
\hline$A^{\prime}=$ & \multicolumn{4}{|c|}{1} \\
\hline \multicolumn{5}{|l|}{ Calculations } \\
\hline Ship-generated wave height $=\mathrm{H}=$ & \multicolumn{4}{|c|}{$1.0 \mathrm{ft}$} \\
\hline \multicolumn{5}{|c|}{ Bhowmik (1975), (1991) } \\
\hline Required Data & 1975 & \multicolumn{3}{|c|}{1991} \\
\hline$V=$ Ship speed & 12 knots & $3.809 \mathrm{mph}$ & 12 knots & $6.173 \mathrm{~m} / \mathrm{sec}$ \\
\hline $\mathrm{D}=$ Vessel draft & \multicolumn{2}{|c|}{$14 \mathrm{ft}$} & \multicolumn{2}{|c|}{$14 \mathrm{ft}$} \\
\hline $\begin{array}{c}x=\text { Distance from sailing line to the point } \\
\text { where the wave height is measured }=\end{array}$ & \multicolumn{2}{|c|}{$300 \mathrm{ft}$} & \multicolumn{2}{|c|}{$300 \mathrm{ft}$} \\
\hline Length of vessel $=\mathrm{L}$ & \multicolumn{2}{|c|}{$115 \mathrm{ft}$} & \multicolumn{2}{|c|}{$115 \mathrm{ft}$} \\
\hline \multicolumn{5}{|l|}{ Calculations } \\
\hline Ship-generated wave height $=\mathrm{H}=$ & \multicolumn{2}{|c|}{$7.8 \mathrm{ft}$} & \multicolumn{2}{|c|}{$2.4 \mathrm{ft}$} \\
\hline \multicolumn{5}{|c|}{ Bhowmik, Demissie, and Gho (1982) } \\
\hline \multicolumn{5}{|l|}{ Required Data } \\
\hline$V=$ Ship speed $=$ & 6 knots & \multicolumn{3}{|c|}{$10.127 \mathrm{ft} / \mathrm{sec}$} \\
\hline $\mathrm{D}=$ Vessel draft $=$ & \multicolumn{4}{|c|}{$14 \mathrm{ft}$} \\
\hline $\begin{array}{c}x=\text { Distance from sailing line to the point } \\
\text { where the wave height is measured }=\end{array}$ & \multicolumn{4}{|c|}{$150 \mathrm{ft}$} \\
\hline Length of Vessel $=\mathrm{L}$ & \multicolumn{4}{|c|}{$115 \mathrm{ft}$} \\
\hline \multicolumn{5}{|l|}{ Calculations } \\
\hline Ship-generated wave height $=\mathrm{H}=$ & & 0.9 & & \\
\hline & Ship-Gen & d Wave Heights & & \\
\hline Ship characteristics $=$ & & laersk Arun: $\underline{\text { http://ww }}$ & ersksealanc & \\
\hline & Sorenson & Neggel (1984) & & 987) \\
\hline Required Data & & & & \\
\hline$V=$ Ship speed $=$ & 12 knots & $13.809 \mathrm{mph}$ & 11 knots & $18.566 \mathrm{ft} / \mathrm{sec}$ \\
\hline $\mathrm{d}=$ Water depth $=$ & & & & \\
\hline $\begin{array}{l}x=\text { Distance from sailing line to point } \\
\text { where the wave height is measured }=\end{array}$ & & & & \\
\hline Vol $=$ Volume of water ship displaced & 80000 tons & $2500000 \mathrm{cu} \mathrm{ft}$ & & \\
\hline Breadth $=$ & - & - & & \\
\hline $\mathrm{A}^{\prime}=$ & - & - & & \\
\hline Dimensionless Variables & & & & \\
\hline Froude Number $=$ & 0.56435 & $\begin{array}{c}0.2<\mathrm{F}<0.8, \mathrm{~F} \text { must } \\
\text { fall between }\end{array}$ & & \\
\hline Distance from sailing line $=x^{*}=$ & & 575 & & \\
\hline Depth $=d^{*}=$ & & 487 & & \\
\hline
\end{tabular}




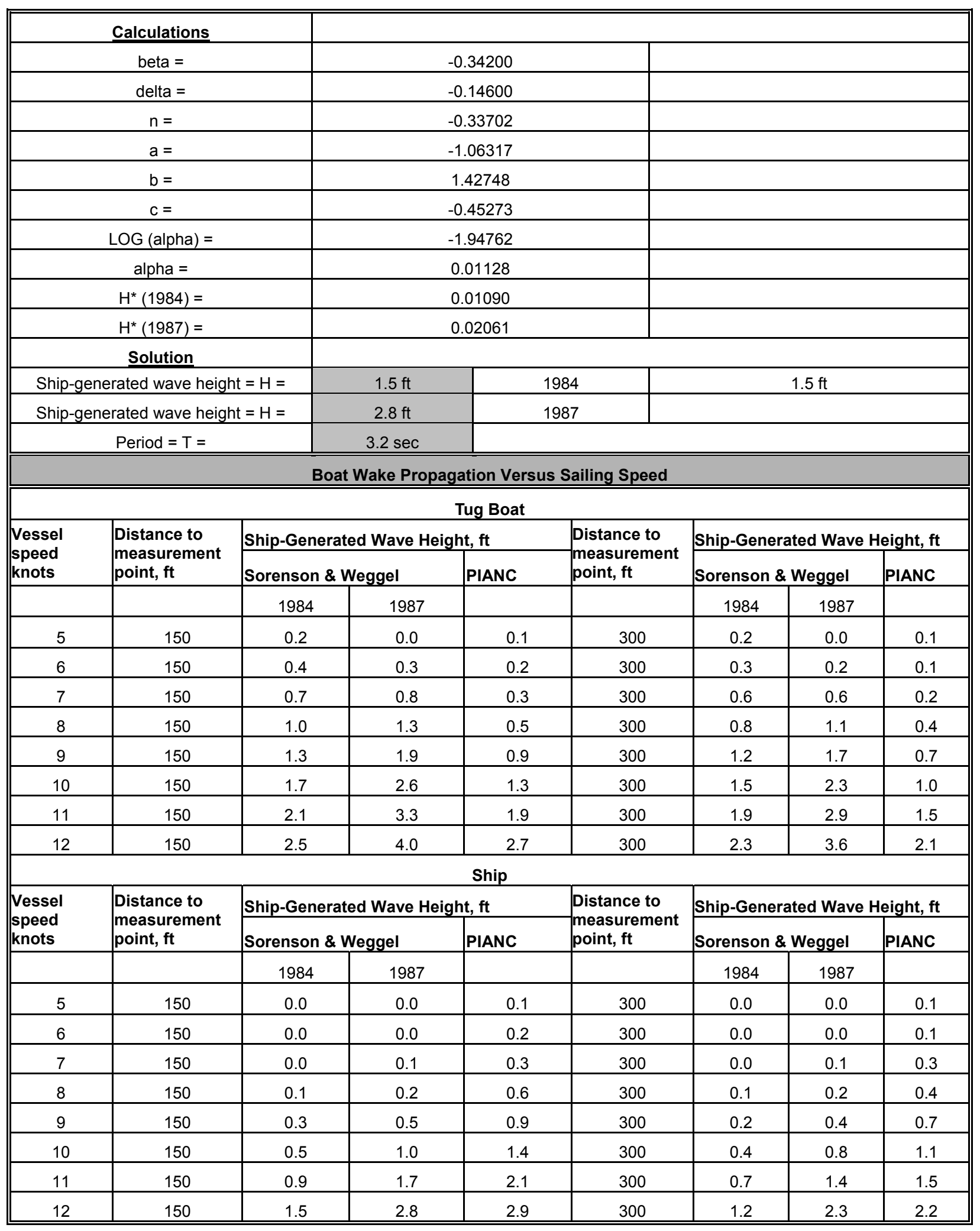




\section{Appendix E}

\section{Essential Fish Habitat for Life}

History Stages of Managed Species in Vicinity of Artificial Reef Sites in New York ${ }^{1}$

$E=$ eggs,$L=$ larvae,$J=$ juveniles,$A=$ adults

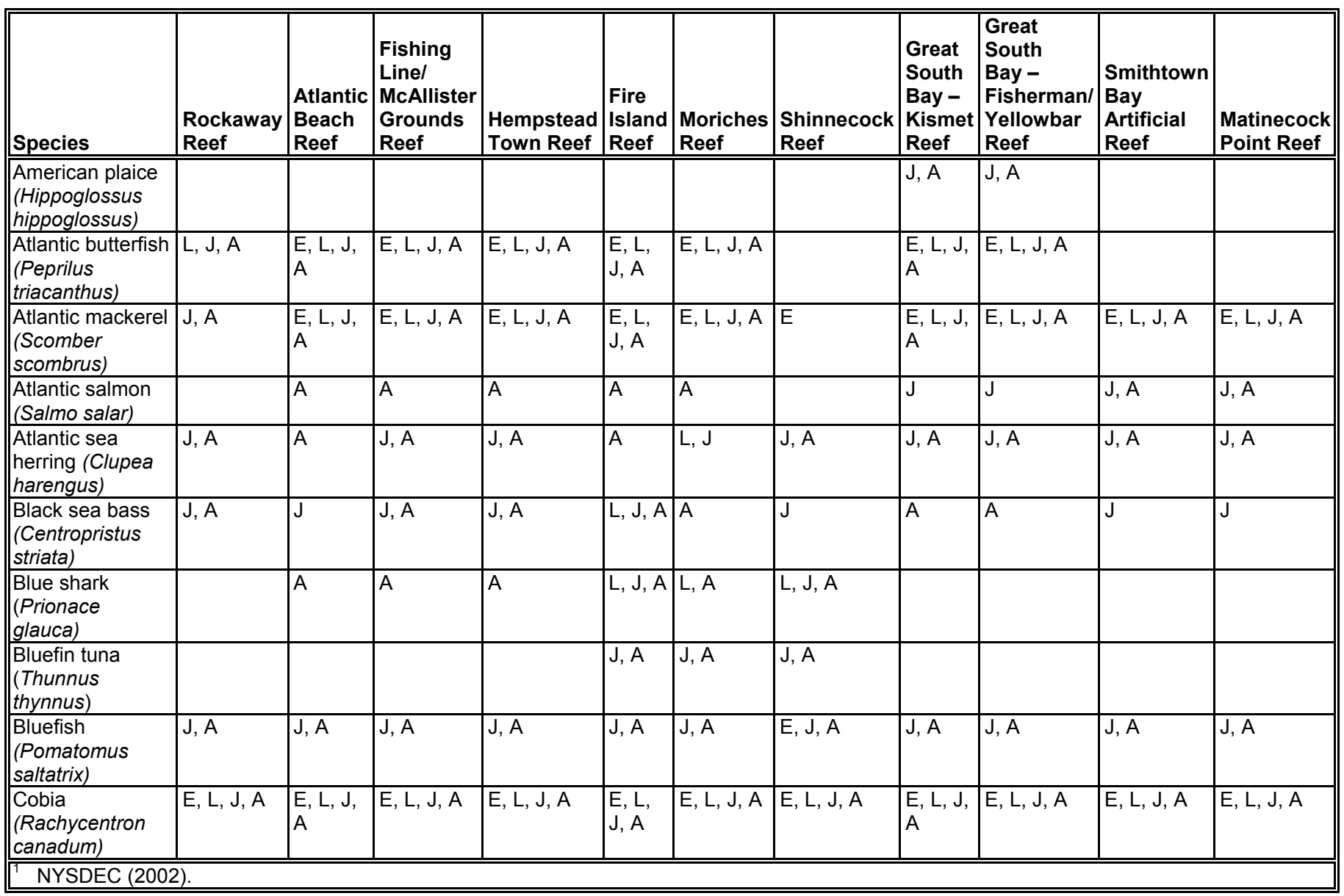




\begin{tabular}{|c|c|c|c|c|c|c|c|c|c|c|c|}
\hline Species & $\begin{array}{l}\text { Rockaway } \\
\text { Reef }\end{array}$ & \begin{tabular}{|l|} 
Atlantic \\
Beach \\
Reef
\end{tabular} & \begin{tabular}{|l|} 
Fishing \\
Line/ \\
McAllister \\
Grounds \\
Reef \\
\end{tabular} & $\begin{array}{l}\text { Hempstead } \\
\text { Town Reef } \\
\text { Town }\end{array}$ & \begin{tabular}{|l|} 
Fire \\
Island \\
Reef \\
\end{tabular} & $\begin{array}{l}\text { Moriches } \\
\text { Reef }\end{array}$ & $\begin{array}{l}\text { Shinnecock } \\
\text { Reef }\end{array}$ & \begin{tabular}{|l|} 
Great \\
South \\
Bay - \\
Kismet \\
Reef \\
\end{tabular} & \begin{tabular}{|l|} 
Great \\
South \\
Bay - \\
Fisherman/ \\
Yellowbar \\
Reef \\
\end{tabular} & \begin{tabular}{|l|} 
\\
Smithtown \\
Bay \\
Artificial \\
Reef \\
\end{tabular} & $\begin{array}{l}\text { Matinecock } \\
\text { Point Reef } \\
\end{array}$ \\
\hline $\begin{array}{l}\text { Common } \\
\text { thresher shark } \\
\text { (Alopias } \\
\text { vulpinus) }\end{array}$ & & & & & $\mathrm{L}, \mathrm{J}, \mathrm{A}$ & & $\overline{L L}, \mathrm{~J}, \mathrm{~A}$ & & & & \\
\hline $\begin{array}{l}\text { Dusky shark } \\
\text { (Charcharinus } \\
\text { obscurus) }\end{array}$ & $L$ & $L$ & $L$ & $L$ & $L, J$ & $L, J$ & $L, J$ & & & & \\
\hline \begin{tabular}{|l|} 
Haddock \\
(Melanogrammus \\
aeglefinus)
\end{tabular} & & & & & & L & $L$ & & & & \\
\hline $\begin{array}{l}\text { King mackerel } \\
\text { (Scomberomorus } \\
\text { cavalla) }\end{array}$ & $E, L, J, A$ & \begin{tabular}{|l} 
E, L, J, \\
A
\end{tabular} & $E, L, J, A$ & $E, L, J, A$ & $\begin{array}{l}\text { E, L, } \\
\text { J, A }\end{array}$ & $E, L, J, A$ & $E, L, J, A$ & \begin{tabular}{|l|} 
E, L, J, \\
A
\end{tabular} & $E, L, J, A$ & $E, L, J, A$ & $E, L, J, A$ \\
\hline \begin{tabular}{|l|} 
Long finned \\
squid (Loligo \\
pealei)
\end{tabular} & & & $\mathrm{J}$ & $J$ & $\mathrm{~J}$ & & $J, A$ & & & & \\
\hline $\begin{array}{l}\text { Monkfish } \\
\text { (Lophius } \\
\text { americanus) }\end{array}$ & $E, L$ & $E, L, A$ & $E, L$ & $E, L$ & $E, L$ & $E, L$ & $E, L$ & & & & \\
\hline $\begin{array}{l}\text { Ocean pout } \\
\text { (Macrozoarces } \\
\text { americanus) }\end{array}$ & & & & & $\begin{array}{l}\text { E, L, } \\
\text { A }\end{array}$ & $E, L, A$ & $E, L, A$ & & & $E, L, A$ & \\
\hline $\begin{array}{l}\text { Ocean quahog } \\
\text { (Artica islandica) }\end{array}$ & & & & & $J, A$ & & $\mathrm{~J}, \mathrm{~A}$ & & & & \\
\hline $\begin{array}{l}\text { Pollock } \\
\text { (Pollachius } \\
\text { virens) }\end{array}$ & & $\mathrm{J}$ & $J$ & $J$ & $\mathrm{~J}$ & & & $\mathrm{~J}$ & $\mathrm{~J}$ & $J, A$ & $\mathrm{~J}, \mathrm{~A}$ \\
\hline $\begin{array}{l}\text { Red hake } \\
\text { (Urophycis } \\
\text { chuss) }\end{array}$ & $E, L, J$ & $E, L, J$ & $E, L, J$ & $E, L, J$ & $E, L, J$ & $E, L, J, A$ & $E, L, J$ & & & $E, L, J, A$ & $E, L, J, A$ \\
\hline $\begin{array}{l}\text { Sand tiger shark } \\
\text { (Odontaspis } \\
\text { taurus) }\end{array}$ & $L$ & $L$ & $L$ & $L$ & $L$ & $L$ & $L$ & & & $L$ & $L$ \\
\hline $\begin{array}{l}\text { Sandbar shark } \\
\text { (Charcharinus } \\
\text { plumbeus) }\end{array}$ & $L, J, A$ & L,J,A & $\mathrm{L}, \mathrm{J}, \mathrm{A}$ & $L, J, A$ & $\mathrm{~J}, \mathrm{~L}, \mathrm{~A}$ & $\mathrm{~L}, \mathrm{~J}, \mathrm{~A}$ & $L, J, A$ & & & & \\
\hline $\begin{array}{l}\text { Scup } \\
\text { (Stenotomus } \\
\text { chrysops) }\end{array}$ & $E, L, J, A$ & $J, A$ & $\mathrm{~J}, \mathrm{~A}$ & $J, A$ & $J, A$ & $\mathrm{~J}, \mathrm{~A}$ & $\mathrm{~J}, \mathrm{~A}$ & $\mathrm{~J}, \mathrm{~A}$ & $\mathrm{~J}, \mathrm{~A}$ & $E, L, J, A$ & $E, L, J, A$ \\
\hline $\begin{array}{l}\text { Shortfin mako } \\
\text { shark (Isurus } \\
\text { oxyrhyncus) }\end{array}$ & & & & & $L, J, A$ & $\mathrm{~L}, \mathrm{~J}$ & $L, J, A$ & & & & \\
\hline \begin{tabular}{|l|} 
Skipjack tuna \\
(Katsuwonus \\
pleamis)
\end{tabular} & & & & & $A$ & $A$ & $A$ & & & & \\
\hline $\begin{array}{l}\text { Spanish } \\
\text { mackerel } \\
\text { (Scomberomorus } \\
\text { maculatus) }\end{array}$ & $\mathrm{E}, \mathrm{L}, \mathrm{J}, \mathrm{A}$ & $E, L, J, A$ & $E, L, J, A$ & $E, L, J, A$ & $\begin{array}{l}\text { E, L, } \\
\text { J, A }\end{array}$ & $E, L, J, A$ & $E, L, J, A$ & \begin{tabular}{|l|} 
E, L, J, \\
A
\end{tabular} & $E, L, J, A$ & $E, L, J, A$ & $E, L, J, A$ \\
\hline $\begin{array}{l}\text { Summer flounder } \\
\text { (Paralicthys } \\
\text { dentatus) }\end{array}$ & L, J, A & $J, A$ & $\mathrm{~J}, \mathrm{~A}$ & $J, A$ & $J, A$ & $E, L, J, A$ & $\mathrm{~J}, \mathrm{~A}$ & $\mathrm{~J}, \mathrm{~A}$ & $J, A$ & $\mathrm{~J}$ & $\mathrm{~J}$ \\
\hline \begin{tabular}{|l|} 
Surf clam \\
(Spisula \\
solidissima) \\
\end{tabular} & & & & & $J, A$ & & $A$ & & & & \\
\hline $\begin{array}{l}\text { Tiger shark } \\
\text { (Galeocerdo } \\
\text { cuvieri) }\end{array}$ & & L & $L$ & $L$ & $L, J$ & $L, J$ & $L, J$ & & & & \\
\hline $\begin{array}{l}\text { White shark } \\
\text { (Charcharadon } \\
\text { carcharias) }\end{array}$ & & & & & $\mathrm{J}$ & $\mathrm{J}$ & $\mathrm{J}$ & & & & \\
\hline
\end{tabular}




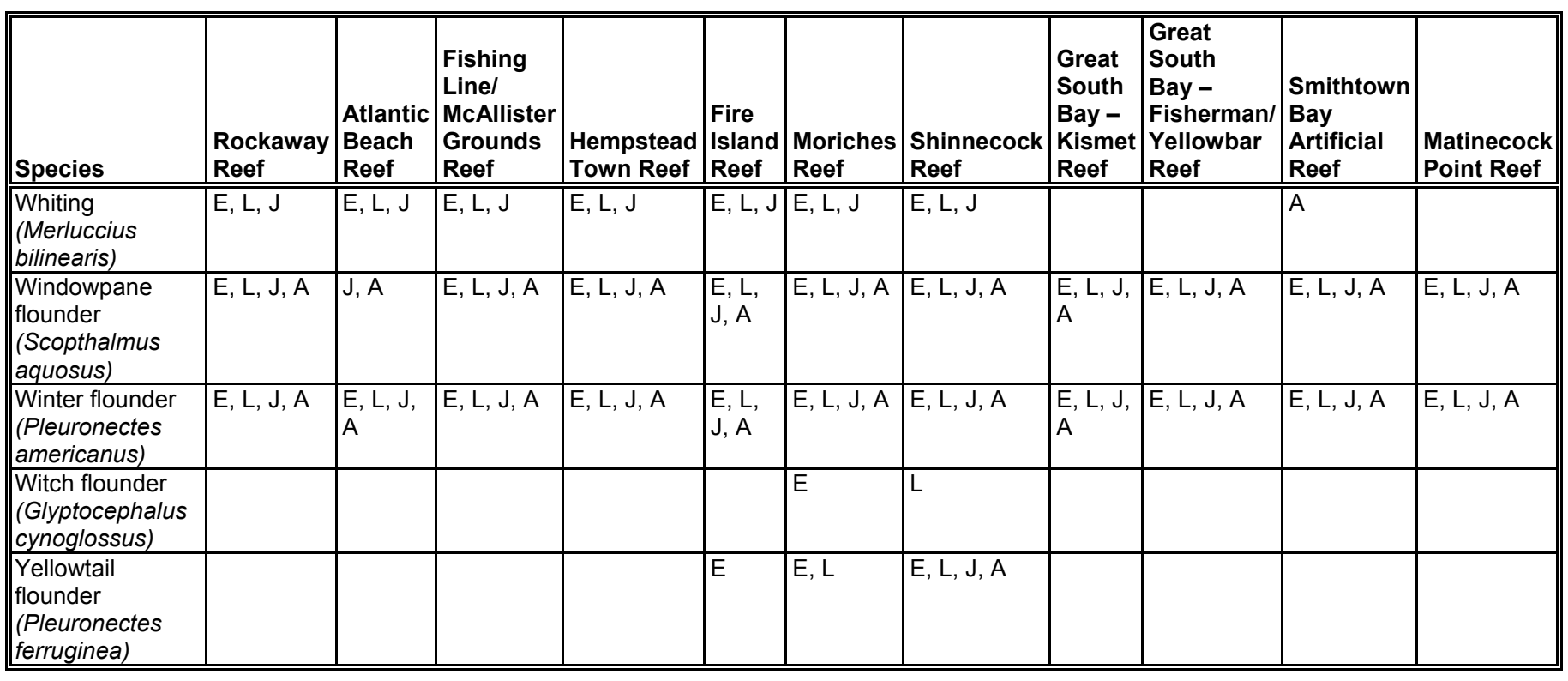




\section{Appendix F Essential Fish Habitat for Life History Stages of Managed Species in Vicinity of Artificial Reef Sites in New Jersey ${ }^{1}$}




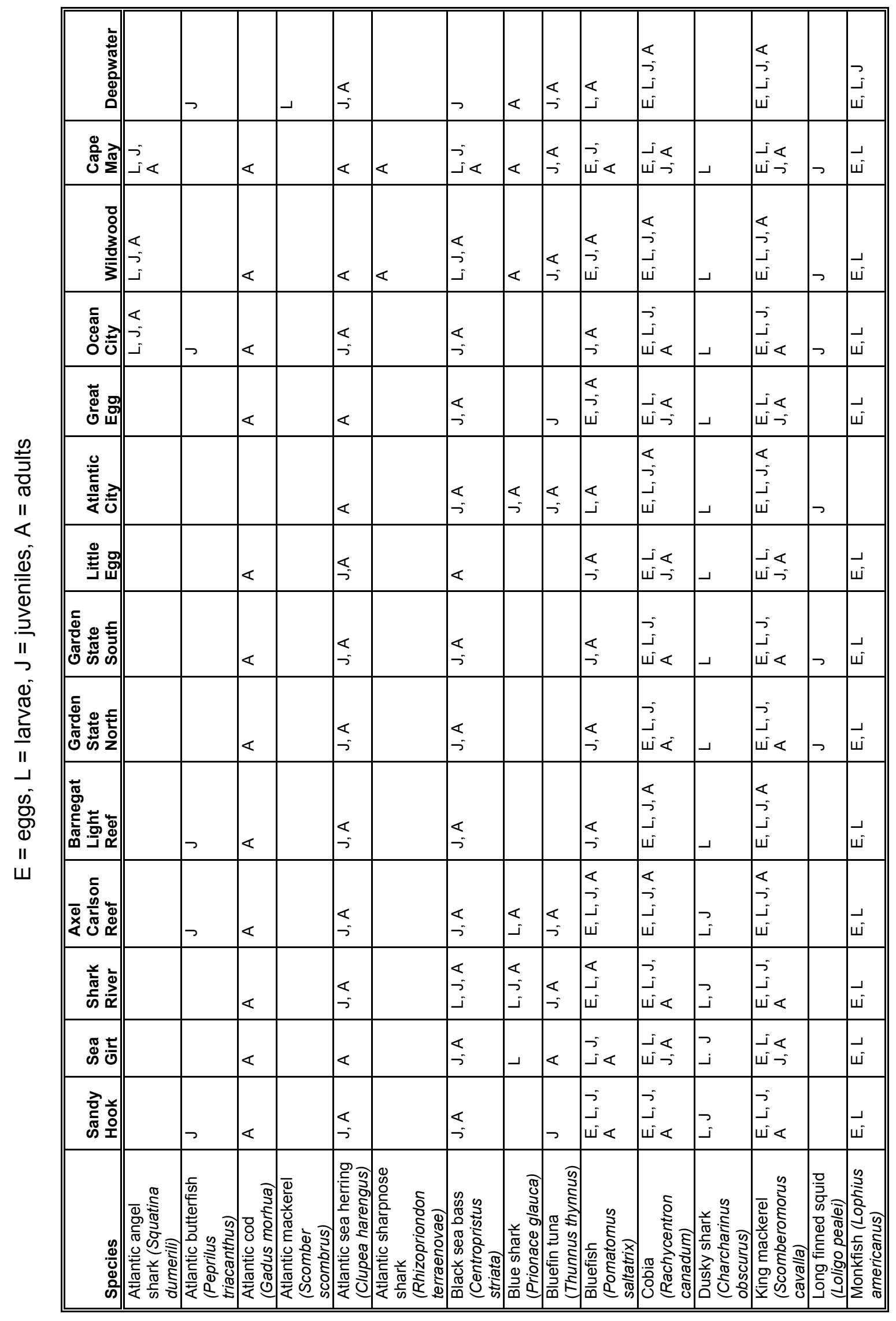




\begin{tabular}{|c|c|c|c|c|c|c|c|c|c|c|c|c|c|c|c|c|}
\hline 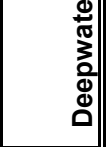 & & 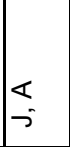 & تَ & & $\ll$ & $\supset$ & 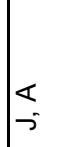 & $\begin{array}{l}\varangle \\
j \\
-5 \\
-5\end{array}$ & $\ll$ & $\begin{array}{l}\varangle \\
5 \\
j \\
-5 \\
w \\
j\end{array}$ & $\supset$ & ث & & $\supset$ & - & \\
\hline 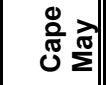 & & & $\mid \vec{\omega}$ & 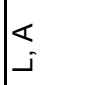 & $\vec{j}$ & ᄀ & $\mid \begin{array}{l}\varangle \\
j\end{array}$ & ت & $\ll$ & $\mid \begin{array}{l}-5 \\
\omega \\
\omega\end{array}$ & $\begin{array}{l}\varangle \\
j\end{array}$ & 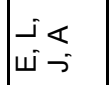 & $\begin{array}{l}\varangle \\
j\end{array}$ & $\supset$ & S & \\
\hline \begin{tabular}{l||}
$\frac{0}{0}$ \\
$\frac{3}{0}$ \\
$\frac{3}{3}$
\end{tabular} & & & تَ & \lrcorner & $\begin{array}{l}\varangle \\
5 \\
5 \\
5\end{array}$ & $\supset$ & 这 & ت & $\ll$ & 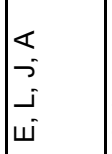 & 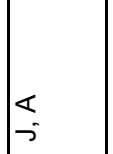 & $\begin{array}{l}\varangle \\
j \\
5 \\
\dot{5} \\
\text { யi }\end{array}$ & 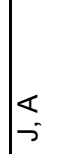 & $\supset$ & s & \\
\hline 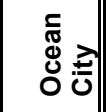 & & & מ & ك & $\begin{array}{l}\varangle \\
j \\
-5\end{array}$ & & 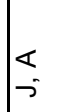 & & & $\begin{array}{l}j \\
j \\
\dot{\omega} \\
\omega\end{array}$ & & $\begin{array}{l}< \\
j \\
j\end{array}$ & $\ll$ & & \lrcorner & \\
\hline 芯 & & & $\begin{array}{l}5 \\
\dot{5} \\
\text { w }\end{array}$ & & $\begin{array}{l}\varangle \\
5 \\
5 \\
5\end{array}$ & & $\varangle$ & $\supset$ & & 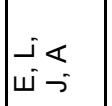 & $\ll$ & $\begin{array}{l}-5 \\
\omega \\
\omega\end{array}$ & $\varangle$ & & - & \\
\hline 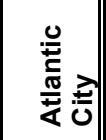 & & & تَ & & $\begin{array}{l}4 \\
5 \\
5\end{array}$ & & $\varangle$ & $\begin{array}{l}4 \\
5 \\
5\end{array}$ & $\ll$ & $\begin{array}{l}\varangle \\
j \\
5 \\
\text { w } \\
\end{array}$ & $\ll$ & 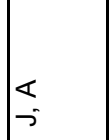 & $<$ & $\supset$ & تَ & \\
\hline 异 嵒 & & & دَ & & $\mid \begin{array}{l}j \\
i<<\end{array}$ & & $\varangle$ & & & 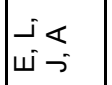 & & 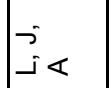 & $\leqslant$ & & \lrcorner & \\
\hline 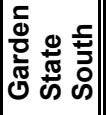 & & & تَ & & & & 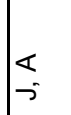 & & & $\begin{array}{l}j \\
j \\
j \\
\omega \\
\omega\end{array}$ & 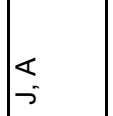 & $\begin{array}{l}\varangle \\
j\end{array}$ & $\begin{array}{l}\varangle \\
j\end{array}$ & & \lrcorner & \\
\hline 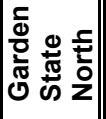 & & & تَ & & $\begin{array}{l}< \\
j \\
-5\end{array}$ & & $\varangle$ & & & $\begin{array}{l}5 \\
5 \\
\omega \\
\omega\end{array}$ & $\ll$ & $\varangle$ & 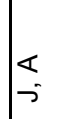 & & \lrcorner & \\
\hline 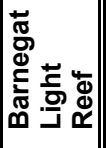 & & & تَ & & $\begin{array}{l}\varangle \\
5 \\
-5\end{array}$ & & $\varangle$ & & & $\begin{array}{l}\varangle \\
5 \\
-5 \\
-5 \\
\text { w }\end{array}$ & & $\begin{array}{l}\varangle \\
5 \\
5\end{array}$ & $<$ & & \lrcorner & \\
\hline 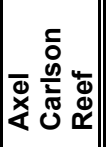 & $\mid \begin{array}{l}\varangle \\
- \\
\omega \\
\omega\end{array}$ & & $\begin{array}{l}\varangle \\
5 \\
5 \\
5 \\
\text { w }\end{array}$ & & $\begin{array}{l}< \\
-5 \\
5 \\
5\end{array}$ & & $\varangle$ & $\supset$ & $\ll$ & $\begin{array}{l}\varangle \\
5 \\
5 \\
5 \\
-5\end{array}$ & & $\begin{array}{l}\varangle \\
5 \\
5 \\
-5 \\
\omega\end{array}$ & & 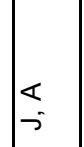 & تَ & \\
\hline 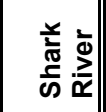 & $\mid \begin{array}{l}j \\
j \\
\dot{5} \\
\dot{\omega}<\end{array}$ & $<$ & كَ & & $<$ & & $\ll$ & $\begin{array}{l}\varangle \\
j \\
j \\
-5\end{array}$ & $\ll$ & $\begin{array}{l}j \\
j \\
\dot{5}<\end{array}$ & & $\begin{array}{l}5 \\
5 \\
\text { u }\end{array}$ & $\mid \begin{array}{l}\varangle \\
j\end{array}$ & & تَ & b \\
\hline œ & 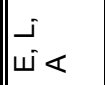 & & حَد & & $\mid \begin{array}{l}j \\
i<<\end{array}$ & & $\mid \begin{array}{l}\varangle \\
5\end{array}$ & $\mid \begin{array}{l}j \\
i<<\end{array}$ & $\ll$ & 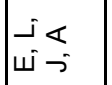 & & $\varangle$ & & & تَ & \\
\hline 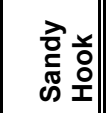 & & $<$ & تَ & \lrcorner & $\begin{array}{l}\varangle \\
j \\
-5 \\
-j\end{array}$ & & $\leqslant$ & \lrcorner & $<$ & $\begin{array}{l}j \\
5 \\
\dot{\omega}<\end{array}$ & & $\ll$ & & & ـ & \\
\hline \begin{tabular}{l|l}
$\frac{\mathfrak{d}}{\mathrm{c}}$ \\
$\stackrel{\mathrm{d}}{\omega}$ \\
$\mathrm{c}$
\end{tabular} & 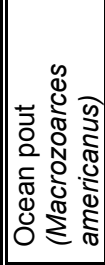 & 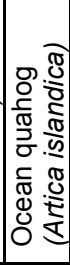 & 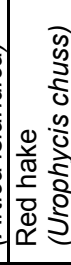 & 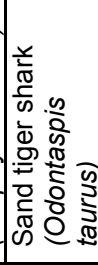 & 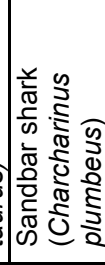 & 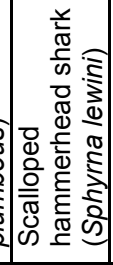 & 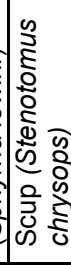 & 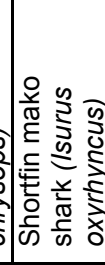 & 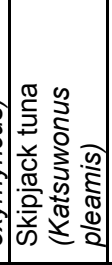 & 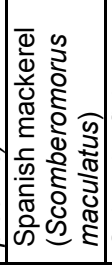 & 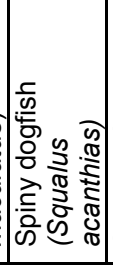 & 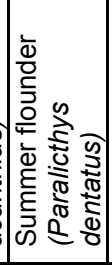 & 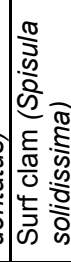 & 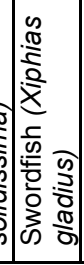 & 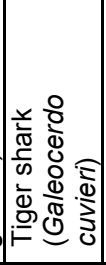 & 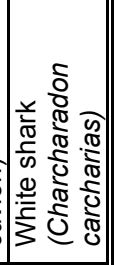 \\
\hline
\end{tabular}




\begin{tabular}{|c|c|c|c|c|c|}
\hline 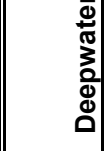 & $\mid \begin{array}{l}3 \\
-5 \\
\omega \\
\omega\end{array}$ & $\begin{array}{l}\varangle \\
-5 \\
\text { ت }\end{array}$ & & \lrcorner & تَ \\
\hline$\stackrel{0}{\frac{0}{\pi}} \frac{\pi}{\Sigma}$ & 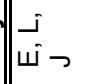 & 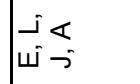 & $\mid \begin{array}{l}- \\
\dot{\omega}\end{array}$ & $\mid \overrightarrow{\mid}$ & $\mid$\begin{tabular}{|c}
\lrcorner \\
\end{tabular} \\
\hline $\begin{array}{l}0 \\
\vdots \\
\frac{3}{0} \\
3 \\
3\end{array}$ & 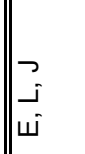 & $\begin{array}{l}\varangle \\
5 \\
5 \\
-5 \\
\omega\end{array}$ & $\begin{array}{c}\varangle \\
j \\
-5 \\
-j \\
\omega\end{array}$ & $\mid$\begin{tabular}{|c}
$\Delta$ \\
\end{tabular} & $\mid \vec{\omega}$ \\
\hline 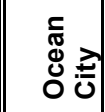 & & $\begin{array}{l}5 \\
\dot{5} \\
\text { is }\end{array}$ & $\begin{array}{l}5 \\
\dot{5} \\
\text { wi }<\end{array}$ & & \\
\hline 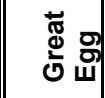 & & 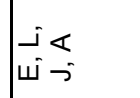 & & | & $\mid \vec{\omega}$ \\
\hline 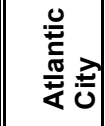 & & $\begin{array}{l}\varangle \\
5 \\
\text { w }\end{array}$ & & | & |س \\
\hline 导 。 & & 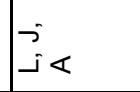 & & & \\
\hline 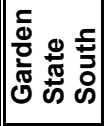 & & $\begin{array}{l}j \\
-5 \\
\dot{j}<\end{array}$ & $\begin{array}{l}j \\
-5 \\
\omega \\
\omega\end{array}$ & 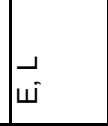 & $\mid \vec{\omega}$ \\
\hline 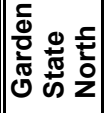 & & $\begin{array}{l}\dot{5} \\
j \\
\dot{\omega} \\
\dot{\omega}<\end{array}$ & $\begin{array}{l}5 \\
5 \\
\dot{\omega}<\end{array}$ & $\mid \breve{u}$ & $\mid \vec{u}$ \\
\hline 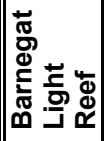 & & $\begin{array}{l}\varangle \\
5 \\
5 \\
5 \\
\text { w }\end{array}$ & 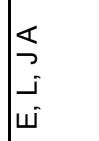 & |山 & $\mid \vec{\omega}$ \\
\hline 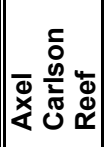 & 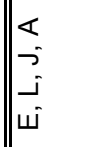 & $\begin{array}{l}\varangle \\
5 \\
5 \\
\omega \\
\omega\end{array}$ & $\begin{array}{l}\varangle \\
5 \\
5 \\
-5 \\
\omega\end{array}$ & $\mid \vec{\Delta}$ & ـَ \\
\hline 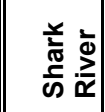 & 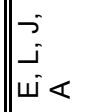 & $\begin{array}{l}\varangle \\
5 \\
\text { w }\end{array}$ & $\begin{array}{l}\overrightarrow{5} \\
\dot{5} \\
\dot{\omega}<\end{array}$ & \lrcorner & $\begin{array}{l}\dot{5} \\
\dot{3} \\
\dot{u} \ll\end{array}$ \\
\hline œ : & دَ & $\mid \begin{array}{l}- \\
\omega \\
\omega\end{array}$ & $\mid \begin{array}{ll}-4 \\
\omega \\
\omega\end{array}$ & س & $\mid \vec{\omega}$ \\
\hline $\begin{array}{l}\text { 흔 } \\
\text { 듕 } \\
\text { ஸे 오 }\end{array}$ & 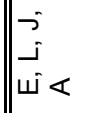 & $\begin{array}{l}5 \\
5 \\
\omega \\
\text { w } 8\end{array}$ & $\begin{array}{l}5 \\
5 \\
\omega \\
\omega\end{array}$ & \lrcorner & تَ \\
\hline 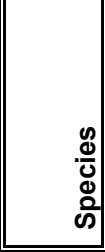 & 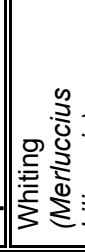 & 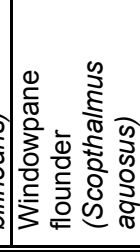 & 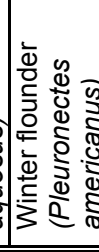 & 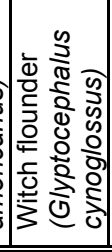 & 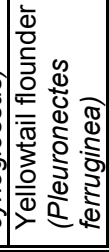 \\
\hline
\end{tabular}




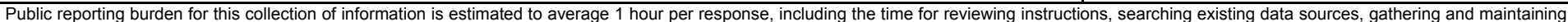

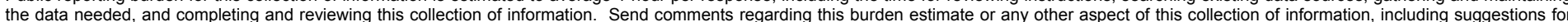

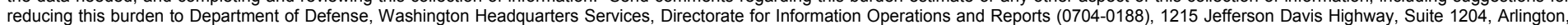

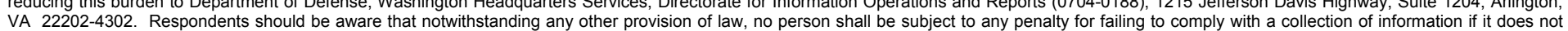
VA 22202-4302. Respondents should be aware that notwithstanding any other provision of law, no person shall be sube
display a currently valid OMB control number. PLEASE DO NOT RETURN YOUR FORM TO THE ABOVE ADDRESS.

\section{TITLE AND SUBTITLE}

Beneficial Use of Dredged Bedrock in the New York/New Jersey Harbor
1. REPORT DATE (DD-MM-YYYY)
July 2003

$$
\text { Final report }
$$

3. DATES COVERED (From - To)

2-2001 to 9-2002

5a. CONTRACT NUMBER

5b. GRANT NUMBER

5c. PROGRAM ELEMENT NUMBER

5d. PROJECT NUMBER

5e. TASK NUMBER

5f. WORK UNIT NUMBER

8. PERFORMING ORGANIZATION REPORT NUMBER

ERDC/EL TR-03-7

10. SPONSOR/MONITOR'S ACRONYM(S)

9. SPONSORING / MONITORING AGENCY NAME(S) AND ADDRESS(ES)

U.S. Army Engineer Research and Development Center

Environmental Laboratory

3909 Halls Ferry Road, Vicksburg, MS 39180-6199;

U.S. Army Corps of Engineers

Washington, DC 20314-1000

12. DISTRIBUTION / AVAILABILITY STATEMENT

Approved for public release; distribution unlimited.

13. SUPPLEMENTARY NOTES

\section{ABSTRACT}

Maintaining economic viability in the rapidly developing global marketplace is a major priority of ports nationwide. It is imperative that commercial ports, such as those in New York (NY) and New Jersey (NJ), evolve to remain competitive with developing global infrastructure. As a consequence, the U.S. Army Engineer District, New York, and the Port Authority of New York and New Jersey are going forward with plans to deepen existing channels for use by the newest generation of container ships. This will include the deepening of several waterways, most prominently the Kill van Kull (KVK), Arthur Kill (AK), and Port Jersey Channel, to a depth of $50 \mathrm{ft}$. A significant by-product of each deepening project will be large amounts of dredged material. In the case of the KVK and AK, the material will be composed predominantly of bedrock. As a result, the U.S. Army Corps of Engineers has commissioned a series of investigations into the viability of beneficially using dredged bedrock in the NY/NJ Harbor.

This report outlines how numerous beneficial use opportunities can become feasible based on bedrock characteristics, case-specific constraints, and applicable regulatory concerns. Beneficial uses of bedrock are promoted by legislative acts. A few uses have been practiced routinely in this region. This report seeks to highlight considerations toward broader uses of bedrock commensurate with projected dredging volumes. This report does not seek to compare the relative merit or cost differential between viable beneficial use opportunities. Information regarding the method for determining the feasibility assessments is detailed.

(Continued)

\section{Subject Terms}

Beneficial use

Dredging

Fishery habitat

Rock

16. SECURITY CLASSIFICATION OF:

\begin{tabular}{|l|l|}
\hline a. REPORT & b. ABSTRACT \\
UNCLASSIFIED & UNCLASSIFIED \\
\hline
\end{tabular}

c. THIS PAGE

UNCLASSIFIED
Shore protection

17. LIMITATION
OF ABSTRACT

\begin{tabular}{l|l}
$\begin{array}{l}\text { 18. NUMBER } \\
\text { OF PAGES }\end{array}$ & \\
\cline { 2 - 2 } & \\
&
\end{tabular}

19a. NAME OF RESPONSIBLE PERSON

19b. TELEPHONE NUMBER (include area code) 


\section{7. (Concluded)}

Battelle Memorial Institute

Coastal Resources and Environmental Management

1212 Route 25A

Stony Brook, NY 11790;

PBS \& J

3859 Centerview Drive

Chantilly, VA 20151;

U.S. Army Engineer District, New York

26 Federal Plaza

New York, NY 10278

\section{4. (Concluded)}

Understanding the type, quantity, and character of material that will be produced as a result of planned dredging projects generates greater understanding of the issues surrounding the beneficial use of dredged bedrock. This information allows project sponsors to determine potential suitable uses for the material. These uses can then be analyzed in more detail to determine the optimal combination of environmental benefits and costs. Once the geological characteristics have been defined, implementation issues can be identified and addressed. These issues can include environmental, economic, federal and non-federal institutional, engineering, and regulatory. In addition, this report offers a logical framework for examining material characteristics and major constraints facing each of the potential beneficial uses of dredged bedrock. 